Q 1) 


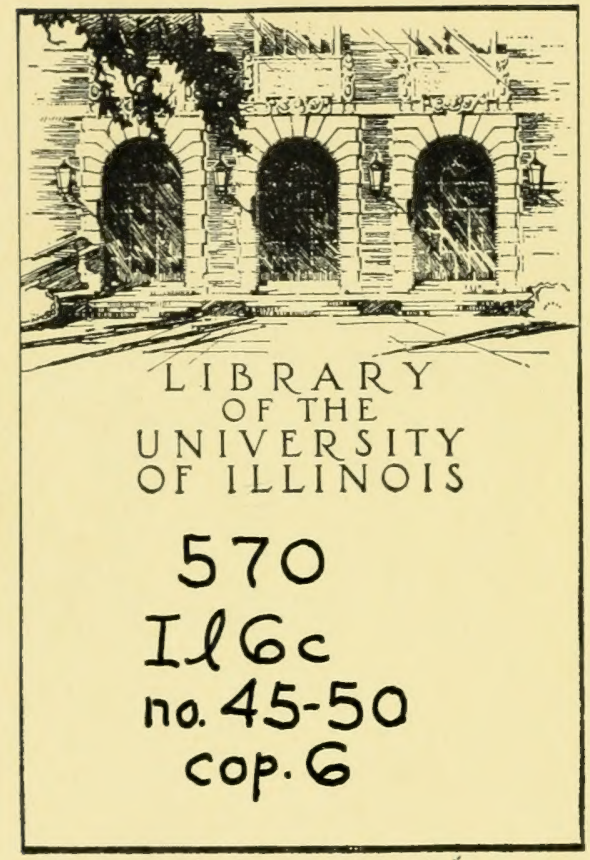

WAIUnit TiSBSUr

SURVEY 

Digitized by the Internet Archive in 2010 with funding from University of Illinois Urbana-Champaign 


Il6c no. 47 cop. 6

\section{ILLINOIS TREES AND SHRUBS:}

THEIR Insect Enemies

L. L. ENG L ISH

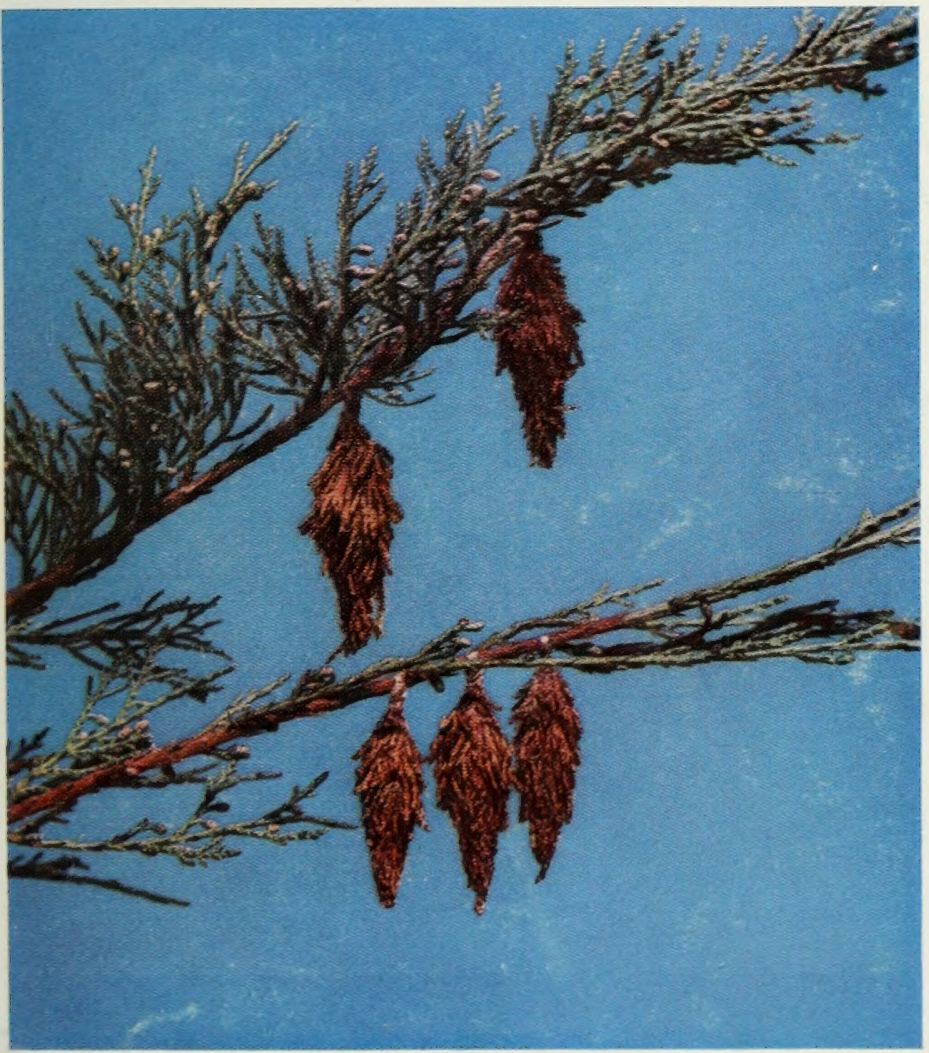

THE LIBRARY OF THE

JUN 251958

UNIVERSITY UF ILLINOIS

ILLINOIS NATURAL HISTORY SURVEY

Circular 47

NATURAL 


\title{
BOARD OF NATURAL RESOURCES AND CONSERVATION
}

Vera M. Binks, Chairman; A. E. Emerson, Ph.D., Biology; L. H. Tiffany, Ph.D., Forestry; Walter II. Newhouse, Ph.D., Geology; Roger Adams, Ph.D., D.Sc., Chemistry; Robert H. Anderson, B.S.C.E., Engineering; W. L. Everits, E.E., Ph.D., Representing the President of the University of Illinois; DeLYTE W. Morris, Ph.D., President of Southern Illinois University

\section{NATURAL HISTORY SURVEY DIVISION, Urbana, Illinois}

\author{
SCIENTIFIC AND TECHNICAL STAFF \\ Harlow B. Mrlls, Ph.D., Chief \\ Bessie B. East, M.S., Assistant to the Chief
}

\section{Section of Economic Entomology}

George C. DecKer, Ph.D., Entomologist and Head

J. H. BIGGER, M.S., Entomologist

L. L. ENGlish, Ph.D., Entomologist

Wruls N. Bruce, Ph.D., Assoriate Entomologist

Norman Gannon, Ph.D., Associate Entomologist

W. H. LuckManN, Ph.D., Associate Entomologist Јонж D. Briggs, Ph.D., Associate Entomologist Ronald H. MeYer, M.S., Assistant Entomologist JoHN D. PAschKe, Ph.D., Assistant Entomologist Robert Snetsinger, M.S., Field Assistant JohN P. KRAMER, M.S., Laboratory Assistant Eugene M. Bravi, M.S., Research Assistant Richard B. Drsart, B.S., Technical Assistant Albert Salako, B.S., Technical Assistant Earl Stadelbacher, B.S., Technical Assistant SUE E. Warkins, Technical Assistant

H. B. PetTy, Ph.D., Extension Specialist in Entomology* Stevenson Moore, III, Ph.D., Extension Specialist in Entomology*

H. B. Cunningham, M.S., Research Associate* John W. Matteson, M.S., Research Associate* Clarence E. White, B.S., Research Assistant* John Arthur Lowe, B.S., Research Assistant* Charles Le Sar, B.S., Research Assistant* Louise Zingrove, B.S., Research Assistant* Mary E. Mann, R.N., Research Assistant*

\section{Section of Faunistic Surveys and Insect Identification} H. H. Ross, Ph.D., Systematic Entomologist and Head Milton W. Sanderson, Ph.D., Taxonomist

Lewis J. Stannard, JR., Ph.D., Associate Taxonomist Philip W. Smith, Ph.D., Associate Taxonomist LeONORA K. Gloyd, M.S., Assistant Taxonomist R. B. Ser.ANDER, Ph.D., Assistant Taxonomist EDWARD L. Mockford, M.S., Technical Assistant Thelma H. Overstreet, Technical Assistant

\section{Section of Aquatic Biology}

George W. Bennetr, Ph.D., Aquatic Biologist and Head Willtam C. Starrett, Ph.D., Aquatic Biologist R. W. Larimore, Ph.D., Associate Aquatic Biologist David H. Buck, Ph.D., Assnciate Aquatic Biologist Robert C. Hiltibran, Ph.D., Assnciate Biorhemist Donald F. Hansen, Ph.D.. Assistant Aquatic Biologist William F. Childers, M.S., Assistant Aquatic Biologist Јонn C. Cralley, B.S., Field Assistant

Richard E. Bass, Field Assistant

Robert D. Crompton, Fie!d Assistant
Section of Aquatic Biology-continued

M. A. Whrtacre, M.A., Assistant Aquatic Biologist*

Arnold W. Fritz, B.S., Field Assistant*

David J. McGisty, Field Assistant*

PAUL FreY, B.S., Laboratory Assistant*

\section{Section of Applied Botany and Plant Pathology}

J. Cedric Carter, Ph.D., Plant Pathologist and Head

J. L. Forsberg, Ph.D., Plant Pathologist

G. H. BOEWE, M.S., Associate Botanist

Robert A. Evers, Ph.D., Associate Botanist

R. J. Campana, Ph.D., Associate Plant Pathologist

Robert Dan Neely, Ph.D., Assistant Plant Pathologist

E. B. Himelick, M.S., Assistant Plant Pathologist

Rovenia F. Fitz-Gerald, B.A., Technical Assistant

\section{Section of Wildlife Research}

Thomas G. Scotт, Ph.D., Game Specialist and Head

RALPH E. YEATTER, Ph.D., Game Specialist

Carl O. Mohr, Ph.D., Game Specialist

F. C. Bellrose, B.S., Game Specialist

Richard R. Graber, Ph.D., Associate Wildlife Specialist W. R. Hanson, Ph.D., Associate Game Specialist

H. C. Hanson, M.S., Associate Game Specialist

William R. Hawkins, B.A. Technical Assistant

Frances D. RobBins, B.A., Technical Assistant

Virginia A. Langdon, Technical Assistant

Howard Crum, JR., Field Assistant

Rexford D. Lord, D.Sc., Project Leader*

Frederick Greeley, Ph.D., Project Leader*

Glen C. Sanderson, M.A., Project Leader*

Paul A. Vous, JR., B.S., Project Leader*

TACK A. Ellis, M.S.. Project Leader*

Ronald F. Labisky, M.S.. Project Leader

Thomas R. B. Bark, M.V.Sc., M.R.C.V.S., Research Assistant*

Bobbie Joe Verts, M.S., Field Mammalogist*

\section{Section of Publications and Public Relations}

Tames S. Ayars, B.S.. Technical Editor and Head

Blanche P. Young, B.A.. Assistant Technical Editor Diana R. Braverman, B.A., Assistant Technical Editor William E. Clark, Assistant Technical Photographet William D. Wood, B.S., Technical Assistant

\section{Technical Library}

Ruth R. Warrick, B.S., B.S.L.S., Technical Librarian Nell Mrles, M.S., B.S.L.S., Assistant Technical Librarian

CONSULTANTS: Herpetology. Hobart M. Smith, Ph.D., Associate Professor of Zoology, University of Illinois Parasitology, Norman D. Levine, Ph.D., Professor of Veterinary Parasitology and of Veterinary Rerearch. Universit. of Illinois; Wilnlife Research. Willard D. Krimstra, Ph.D., Associate Professor of Zoology and Director o Co-operative Wildlife Resecrch, Southern Illinois University.

* Employed on co-operative projects with one of several agencies: University of Illinois, Illinois Agricultura Extension Service, Illinois Department of Conservation, United States Army Surgeon General's Office, United State Department of Agriculture, United States Fish and Wildlife Service, United States Public Health Service, and others

This paper is a contribution from the Section of Economic Entomology. 
State OF IllinoIS - William G. Stratton, Governor Department of Registration and Education - Vera M. Binks, Director Natural History Survey Division - Harlow B. Mills, Chief

\section{ILLINOIS TREES AND SHRUBS: THEIR Insect Enemies}

L. L. ENGLISH

\section{ILLINOIS NATURAL HISTORY SURVEY}

Eircular 47

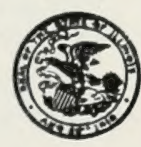




\section{CON TENTS}

About Insects . . . . . . . . 1

Aphids or Plant Lice . . . 2

Scale Insects . . . . . . . 2

Borers $2 . .2$

Leaf Eaters . . . . . . 3

Mites . . . 3

Gall-Producing Insects and Mites

About Trees and Shrubs and Their Pests

Ailanthus (Tree of Heaven)

Ailanthus Webworm

Cynthia Moth

Arborvitae

Bagworm

Arborvitae Leaf Miner

Spruce Spider Mite

Juniper Scale

Ash

Red-Headed Ash Borer . . . 7

Ash Borer . . . 7

Oystershell Scale. . . 8

Fall Webworm . . . . . 9

Birch . . . . . . . . . 11

Bronze Birch Borer . . . . . 11

Birch Skeletonizer . . . . . 11

Boxelder . . . . . . . . . . 11

Boxelder Bug . . . . . . . 11

Boxelder Aphid . . . . . . 12

Eastern Tent Caterpillar . . . 12

Boxwood . . . . . . . . . 14

Boxwood Leaf Miner . . . 14

Catalpa .. . . . . . 14

Catalpa Sphinx . . . . . . 14

Comstock Mealybug . . . 16

Crabs and Hawthorns . . . . 17

Yellow-Necked Caterpillar . . 17

Woolly Hawthorn Aphid . . . 17

European Red Mite . . . . . 18

San Jose Scale. . . . 18

Hawthorn Leaf Miner . . . 20

Dogwood . . . . . . . . . 20

Dogwood Borer . . . . . . 20

Dogwood Scale . . . . . . 20

Douglas Fir . . . . . . . . 20 Cooley Spruce Gall Aphid . . 20

Elm . . . . . 21

Spring Cankerworm . . . . 21

White-Marked Tussock Moth . 23

Fall Webworm . . . . . . 24

Elm Leaf Beetle . . . . . . 24

European Elm Scale . . . 26

Scurfy Scale . . . . . . . . 26

Putnam Scale . . . . . . . 28

Elm Leaf Aphid . . . . . . 29

Woolly Elm Aphid . . . . . 29

Elm Cockscomb Gall Aphid . . 29

Elm Borer . . . . . . 29
Smaller European

Elm Bark Beetle . . . . 31

Banded Elm Leafhopper . . . 33

Mites . . . . . . . . 33

Euonymus . . . . . . . . . . 33

Euonymus Scale . . . . . 33

Hackberry . . 35

Hackberry Nipple Gall Psyllid 35

Witches'-Broom . . . . . 36

Hickory . . . . . . . 36

Yellow-Necked Caterpillar . 36

Hickory Bark Beetle . . . . 36

Hickory Gall Phylloxera . . . 37

Hickory Horned Devil or Regal Moth . . . . 37

Juniper . . . . . . . . . . 37

Juniper Scale . . . . . . 37

Juniper Webworm . . . . 38

Juniper Bark Beetle . . . 38

Spruce Spider Mite . . . 39

Bagworm . . . . . . . . 39

Lilac . . . . . . . . . 40

Lilac Borer . . . . . . . 40

Oystershell Scale . . . 40

Linden . . . . . . . . 40

Elm Spanworm . . . . . 40

Locust . . . . . . . . . . 40

Locust Borer . . . . . 40

Bagworm . . . . . 43

Locust Mite . . . . . . . 43

Mimosa Webworm . . . . 43

Maple . . . . . . . 43

Cottony Maple Scale . . . 43

Maple Bladder-Gall Mite . . 45

Green-Striped Mapleworm . . 46

Flatheaded Apple Tree Borer . 46

Aphids . . . . . . . 47

Pigeon Tremex . . . . . 47

Oak . . . . . . 48

Borers . . . . . . 48

Periodical Cicada . . . . . 48

May Beetles . . . . . . . . 48

Twig Pruner . . . . . . . 48

Oak Kermes . . . . . . 50

Leaf Miners . . . . 51

Gall-Producing Insects . . . 53

Pine . . . . . . . . . . . 53

Sawflies . . . . . 53

White-Pine Weevil . 54

Pine Needle Scale . . . . . 54

Pine Bark Aphid . . . . . . 57

European Pine Shoot Moth . . 57

Nantucket Pine Moth . . . . 57

Zimmerman Pine Moth . . . 58

Poplar . . . . . . 59

Poplar Borer . . . . . . 59

Cottonwood Borer . . . . . 59

Poplar and Willow Borer . . 59 
Carpenterworm . . . . . 59

Cottonwood Leaf Beetle . . . 60

Poplar Tent Maker . . . . .60

Oystershell Scale . . . . . 60

Privet . . . . . . . 60

Privet Thrips . . . . . . 60

Redbud . . . . . . . 62

Oystershell Scale. . . . . 62

Two-Spotted Spider Mite . . 62

Spirea . . . . . . 62

Spirea Aphid . . . . . . 62

Spruce . . . . . . . 62

Spruce Spider Mite : . . 62

Cooley Spruce Gall Aphid . . 64

Eastern Spruce Gall Aphid . . 64

Spruce Bud Scale . . . . 64

Spruce Budworm . . . . . . 65

Pine Needle Scale . . . . . 65

Sycamore . . . . . . . 66

Sycamore Lace Bug . . . . 66

Bagworm . . . . . 66

Borers . . . . . . . 66

Tuliptree . . . . . . . . 66

Tuliptree Scale . . . . . 66
Tuliptree Aphid . . . . . . $66^{\circ}$

Walnut . . . . . . . . . . . . 77

Walnut Caterpillar . . . . 67

Black Walnut Curculio . . .69

Willow . . . . . . . . . 69

Willow Aphid . . . . . . 69

Bagworm . . . . . . . 69

Borers . . . . . . . . . 69

Oystershell Scale . . . . . 69

Yew (Taxus) . . . . . . .69

Black Vine Weevil . . . . 69

Fletcher Scale . . . . . 71

Termites . . . . . . 71

Taxus Mealybug . . . . . 73

Potential Insect Enemies . . . 73

Japanese Beetle . . . . . 73

Gypsy Moth . . . . . . . 75

Brown-Tail Moth . . . . 75

About Insecticides . . . . . . 76

About Spray Equipment

And Its Use . . . . . . 78

Index . . . . . . . . . 83

Spray Preparation Tables . . . 89

Control Measures . . . . . 90

The kodachrome for the cover and most of the photographs for this circular were taken by William E. Clark of the Illinois Natural History Survey. Photographs from outside agencies are credited to those agencies.

\section{TO USERS OF THIS CIRCULAR}

Control measures referred to in this circular are listed on pages 90,91 , and 92 . 


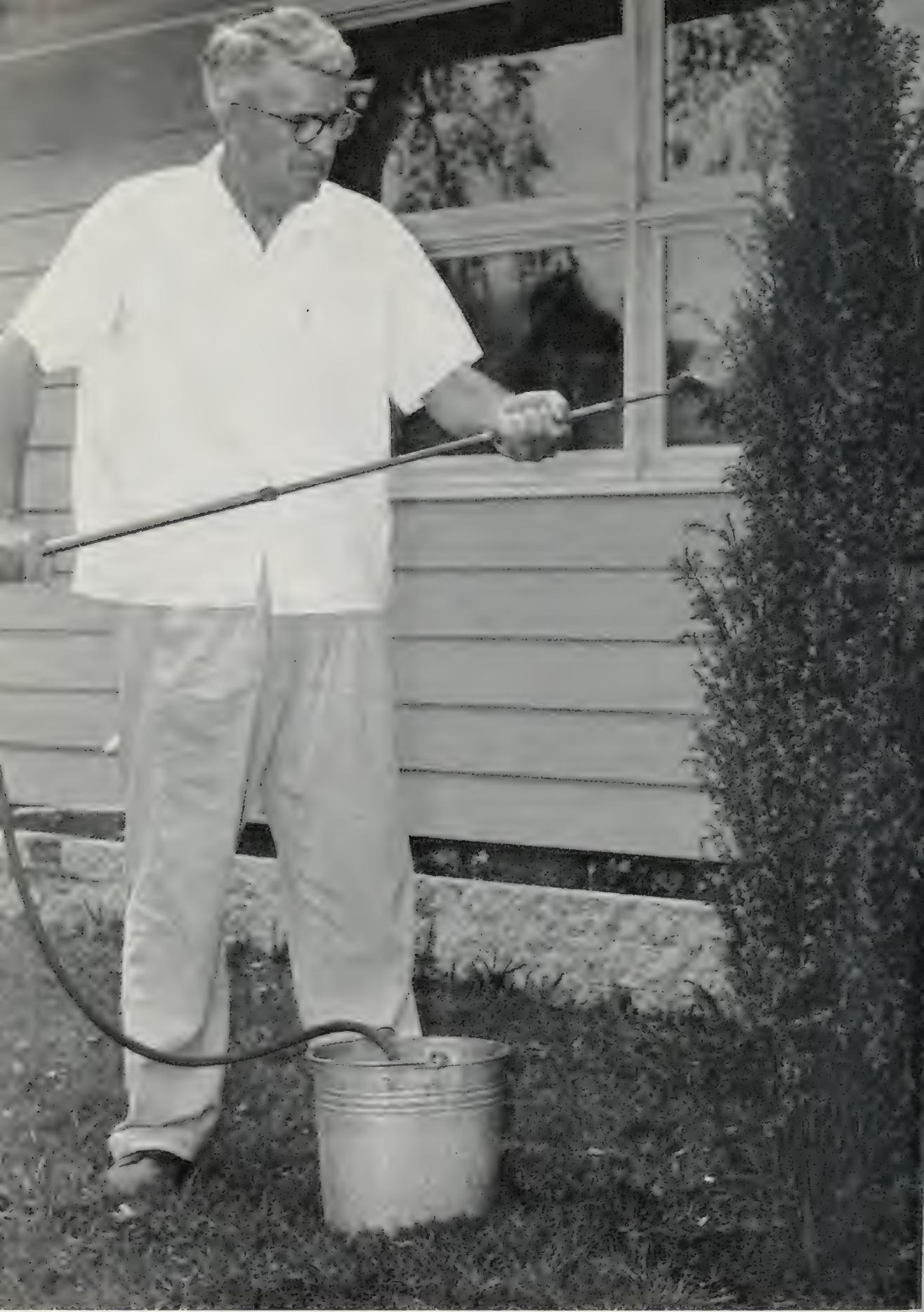

Trombone-type sprayer in use. This is an inexpensive sprayer that is convenient for applying chemicals to limited numbers of shrubs and small trees. 


\section{ILLINOIS TREES AND SHRUBS:}

\section{THEIR Insect Enemies}

\section{L. ENGLISH}

$R_{\text {egardless of their size or cost, trees and shrubs used as orna- }}$ $R$ mentals may be highly prized by their owners as sources of shade or beauty. An important aspect of the care of ornamentals is the prevention of insect damage. Such plants may be severely damaged or even destroyed unless their owners have at least an elementary knowledge of insect pests and the ways in which they can be controlled. To provide help in the recognition of insect pests of trees and shrubs used as ornamentals and to suggest specific measures for control of these pests is the purpose of this circular.

Insects may damage trees and shrubs in many ways. A colony of ravenous caterpillars may strip the foliage from twigs and branches; hordes of aphids may suck the sap from new shoots and leaves, causing them to wilt or to grow abnormally; tiny scale insects may encrust branches and twigs, withdrawing enough food to kill plants outright; borers of many kinds may invade the bark and wood, seriously injuring or killing plants; more subtle but as serious is the damage caused by those insects that carry fungus or virus diseases.

\section{ABOUT INSECTS}

The first essential for effective control of insect pests is vigilance and an interest, which may be acquired, in looking for insects and signs of their damage. To detect the presence of insects before they cause serious damage to valuable trees and shrubs, one should carefully examine the plants at least once a week during the growing season. One should examine deciduous trees in winter, also, when scale insects on them may be seen more easily than when trees are in leaf.

The second essential is at least an elementary knowledge of insects and the ways they reproduce and grow. For example, one should know that while most kinds of insects lay eggs, some, like most of the aphids, give birth to living young. The eggs of insects are of various sizes, shapes, and colors; most of them are small in size and are not easily seen. They are laid singly or in clusters, hidden or in conspicuous places. With few excentions, 
insect eggs cause little or no damage, but many of the animals that hatch from the eggs are destructive.

Insects develop by metamorphosis, or change. The young of some kinds, boxelder bugs for example, look like the adults and reach maturity through a series of molts. The young of kinds that look unlike the adults are called larvae, grubs, caterpillars, or worms. Eggs deposited by moths and butterflies produce caterpillars that feed ravenously and molt several times before they reach maturity. The caterpillars change to pupae (latent stage) for transformation to moths or butterflies. The growth pattern of beetles is similar to that of moths and butterflies. The young of beetles are often called grubs.

The following paragraphs contain information about several kinds of insects and the ways in which they feed.

Aphids or Plant Lice.-There is a species of aphid for almost every species of plant. Aphids are sucking insects, fragile and awkward in appearance. They are most commonly green, pink, or black in color. Each aphid, only one-sixteenth to oneeighth inch long, is well equipped with a stout beak through which it draws great quantities of plant juice as it feeds from place to place on tender plant tissue. Heavy infestations of aphids usually produce a noticeable amount of honeydew, on which a sooty mold may grow. Aphids have an enormous reproductive capacity. Fortunately they have many natural enemies. Lady beetles, both larvae and adults, fatten themselves on aphids, and the larvae of tiny parasitic wasps feed within them.

Scale Insects.- Scale insects, small and inconspicuous, are likely to be overlooked until the branches of infested trees or shrubs are encrusted with them. They are sucking insects that live most of their lives under protective shells or scales. They may kill branches, limbs, and whole trees. Each insect is a mere sack of protoplasm with a threadlike beak thrust into the tissue of the plant it feeds upon. The female in most species of scale insects deposits eggs under her shell. The eggs produce crawlers that move away from the shell to find suitable feeding places. When the crawlers settle and begin to feed, each makes a shell for its own protection.

Borers.-Most borers that attack trees or shrubs are the larvae of beetles or moths. They hatch from eggs deposited on the bark of a tree or shrub. Soon after hatching, they bore into the wood of the plant. Healthy, vigorous trees are unattractive 
to borers. Newly planted trees suffering from transplanting shock, and older trees growing in unfavorable places where little moisture or food is available, become attractive to the pests.

Leaf Eaters.-Severe damage by this group of pests is conspicuous and easy to detect. In many cases, however, damage is not observed until serious defoliation has occurred. The principal leaf eaters are beetles and their larvae (grubs) and the larvae (caterpillars) of moths and sawflies. Damage by these pests is most likely to occur in the spring and early summer.

Mites.-Especially destructive to evergreens, these animals, barely visible to the naked eye, have great reproductive power and attack plants in large numbers. They injure plants by rasping the leaf surfaces and removing the plant juices. Technically, mites are not insects, although closely related to them.

Gall-Producing Insects and Mites.-Galls are abnormal growths appearing as warts or bumps or attractive-looking balls on leaves and twigs. They are of many shapes and sizes, but each kind is characteristic of the animal that produces it. The production of some galls is stimulated by tiny mites too small to be seen with the naked eye. The production of others is stimulated by flies, aphids, and small wasps. A part of the life cycle of the gall-producing animal is spent inside the gall. Most galls do not cause serious damage to the plants on which they are found.

\section{ABOUT TREES AND SHRUBS AND THEIR PESTS}

In the discussion that follows, the host plants are arranged alphabetically. Each pest and the nature of its damage are briefly described; notes on the life history are given for each of the common and destructive pests. The control measures are numbered and are found at the end of the circular, pages 90,91 , and 92 , along with convenient dilution tables, page 89 .

\section{AILANTHUS (TREE OF HEAVEN)}

Ailanthus Webworm, Attera aurea (Fitch), fig. 1.-An occasional pest of ailanthus, or tree of heaven, the olive-brown caterpillar of this species feeds on the leaves under a thin web. Sometimes it attacks the petioles, causing the leaves to wilt.

Control Measure 1 or 2 (end of circular). 


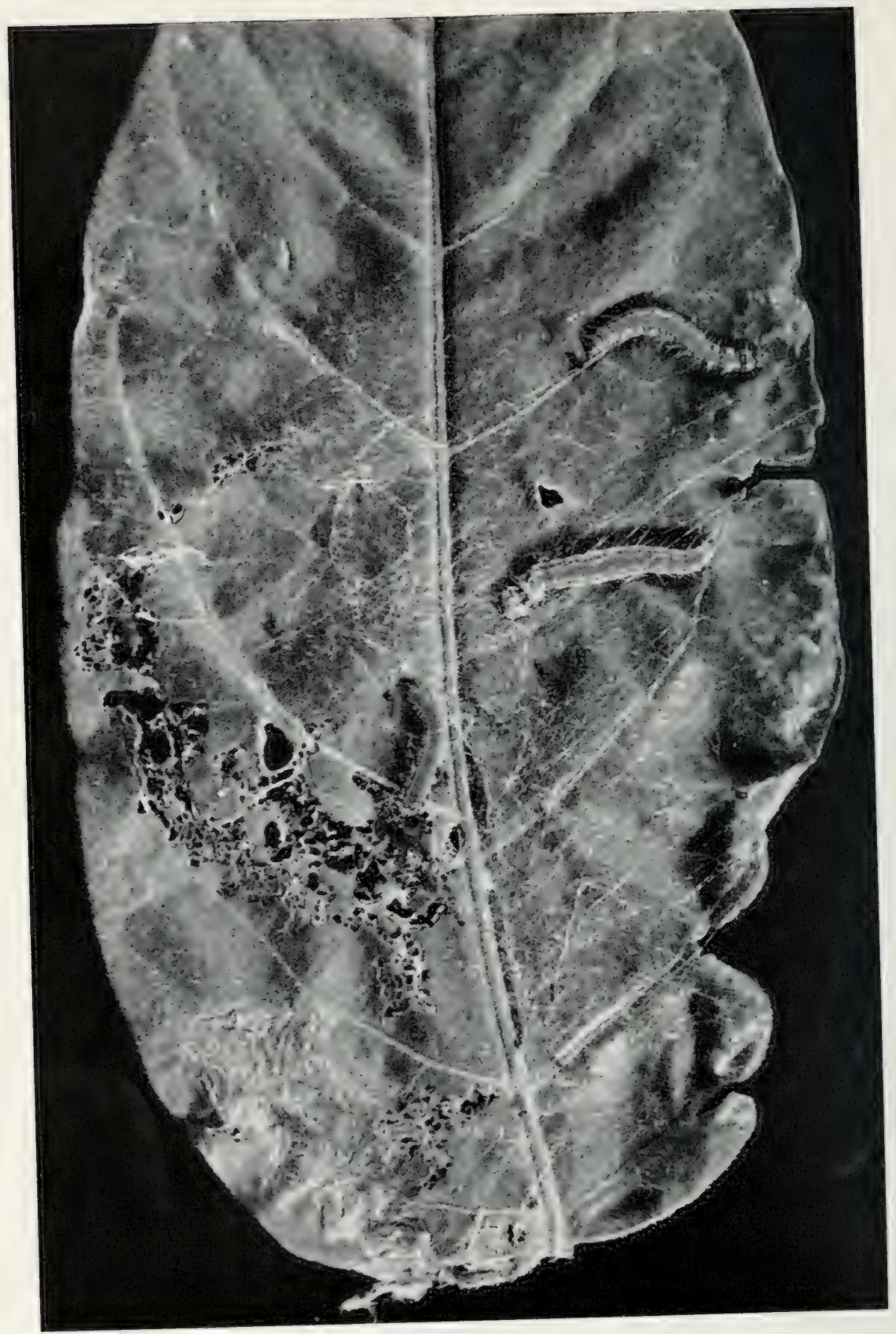

Fir. 1- Ailanthus webworm: larvae. The olive-brown larvae or worms feed on the surfaces of leaves. 
Cynthia Moth, Samia cynthia (Drury).-The 3-inch, green caterpillar of this species has black dots and blue tubercles on its back. It feeds on the leaves of the tree of heaven. The adults are handsome brown moths, each with a wingspread of 6 to 8 inches. Sometimes caterpillars of this kind defoliate the trees on which they feed.

Control Heasure 1 or 2 (end of circular) while small caterpillars are feeding.

\section{ARBORVITAE}

Bagworm, Thyridopteryx ephemerceformis (Haw.), fig. 2. - A widely distributed common pest, the larva of this species feeds ravenously on both evergreen and deciduous trees and

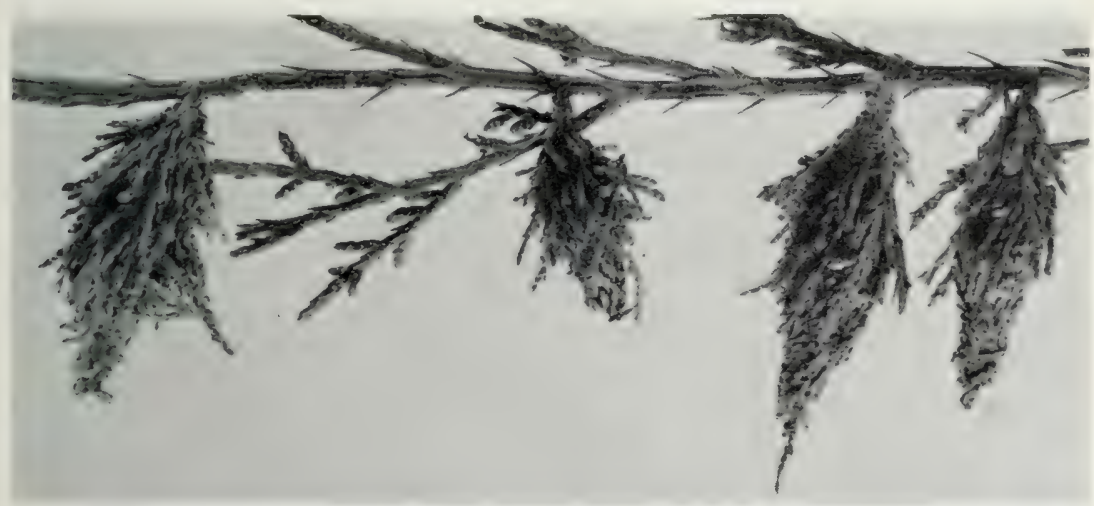

Fig. 2. - Bagworm: cases or bags constructed by larvae. Some of the bags shown here are almost filled with eggs laid by adult females of the bagworm. Eggs that survive the winter hatch in early summer. The appearance of bags varies with the kinds of leaves from which the larvae have made them.

shrubs. Usually evergreens defoliated by bagworms die. Some of the spindle-shaped bags hanging from trees and shrubs during the winter contain eggs that produce a crop of worms in the following spring or summer. In southern Illinois, these eggs hatch usually during the latter part of May, in central Illinois during the first part of June, and in northern Illinois during the latter part of June. Newly hatched larvae are easily overlooker. After leaving the mother bag, a small larva feeds on nearby foliage and begins to build a tough bag for itself with silken 
thread and with bits of foliage taken from the host plant. Hence, bags on maples, for example, look different from those on arborvitae.

Each bag is enlarged to accommodate the rapidly growing larva inside and is carried everywere the larva goes. The larva sticks its head out of the bag to feed, but quickly retreats when disturbed by birds or other enemies. By late summer, when the bag is $1^{1}$. to 2 inches long, the larva matures, pupates, and transforms to the adlult stage. The adult male, a black, fuzzy moth, emerges from its bag and flies about to mate with the wingless female, which remains in the bag while she lays 500 or more eggs. After egg-laying, the female dies. The bagworm produces only one generation a year in Illinois.

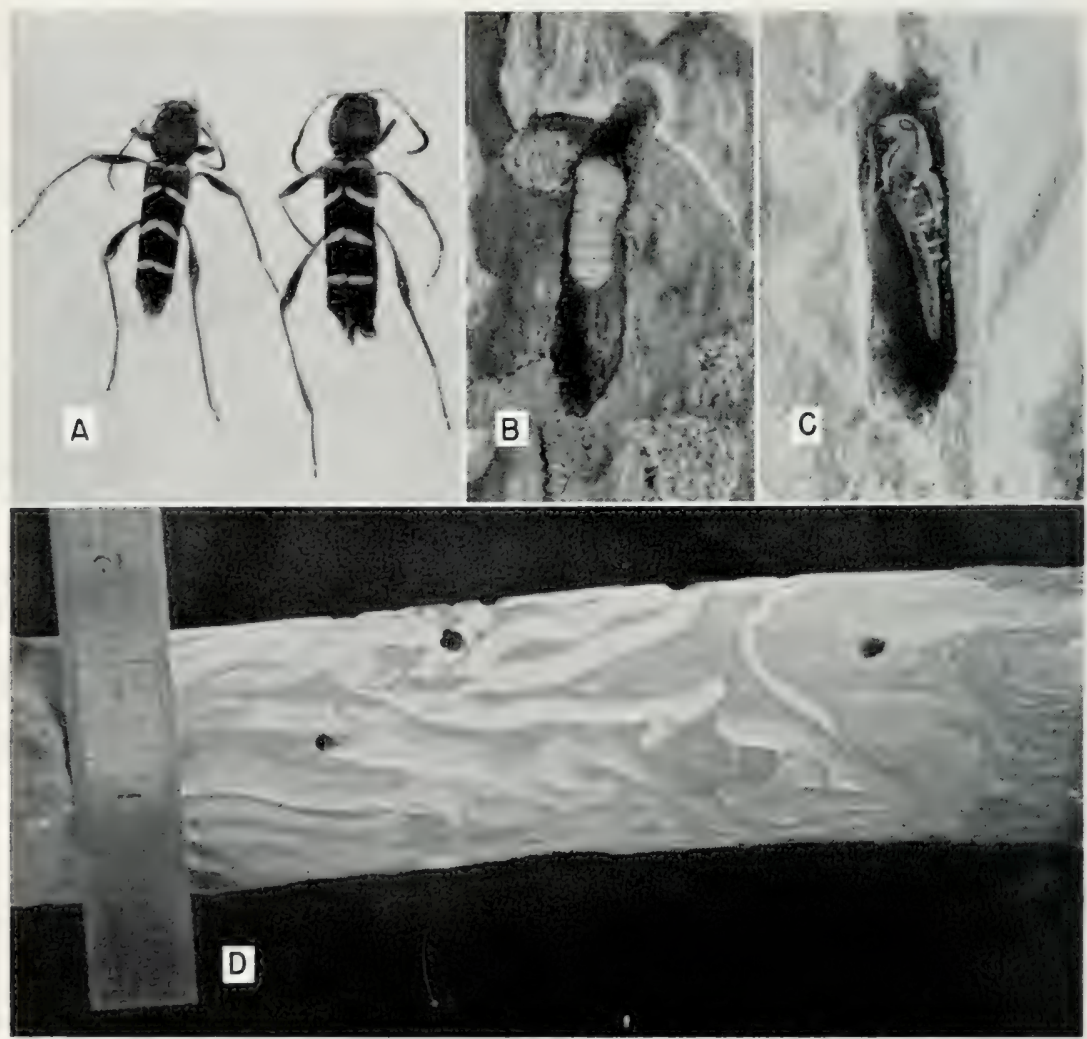

Fig. 3.-Red-headed ash borer: $A$, adults; $B$, larva or grub; $C$, adult ready to emerge from its pupal case; $D$, furrows made by larvae in sapwood and holes through which adults emerged. 
Because only the male adult flies, infestations of bagworms are spread principally in the larval and egg stages. Small larvae suspended by their silken threads may be carried by the wind for considerable distances. Larger larvae often crawl from one plant to another in search of food. Larvae or bags containing eggs may be inadvertently transported by human beings.

Control Measure 1, 3, or 11 (end of circular) as soon as the eggs hatch. Sprays applied in late summer after the larvae stop feeding, or during the winter, are ineffective. The worm infestation can be reduced by picking and burning the overwintering bags.

Arborvitae Leaf Miner, Argyresthia thuiella (Pack.).Feeding by the leaf-mining caterpillar of this species on the insides of needles causes the tips of arborvitae branches to turn whitish, tan, and brown. Less than one-fourth inch long, each greenish, red-tinged caterpillar comes from one of several eggs deposited on the leaves by a small moth in the spring. This pest may produce more than one generation in a season, and considerable damage may result from its feeding.

Control Measure 2 (end of circular) when moths are flying. The use of DDT may result in a build-up of mites.

Spruce Spider Mite.-See under Spruce. Control Measure? (end of circular).

Juniper Scale, fig. 28.-See under Juniper. Control Measure 3 (end of circular).

\section{$\mathrm{ASH}$}

Red-Headed Ash Borer, Neoclytus acuminatus (F.), fig. 3.The short, white, round-headed grub of this species may girdle small ash trees so severely that they break and fall. The grub tunnels in many directions, mainly in the sapwood. The adults are beetles, each about one-half inch long. Each has a reddish head, which accounts for the common name, and a V-shaped yellow band across the wing covers. The female deposits eggs in crevices of bark in early summer. The young larva bores into the bark, where it feeds and grows until it pupates in late winter.

Control Measure 4 (end of circular).

Ash Borer, Podcsesia s!lingae fraxini (Lug.), fig. 4.-This insect was once considered to be the same as the lilac borer, but it now appears to be different and to be limited to ash and moun- 


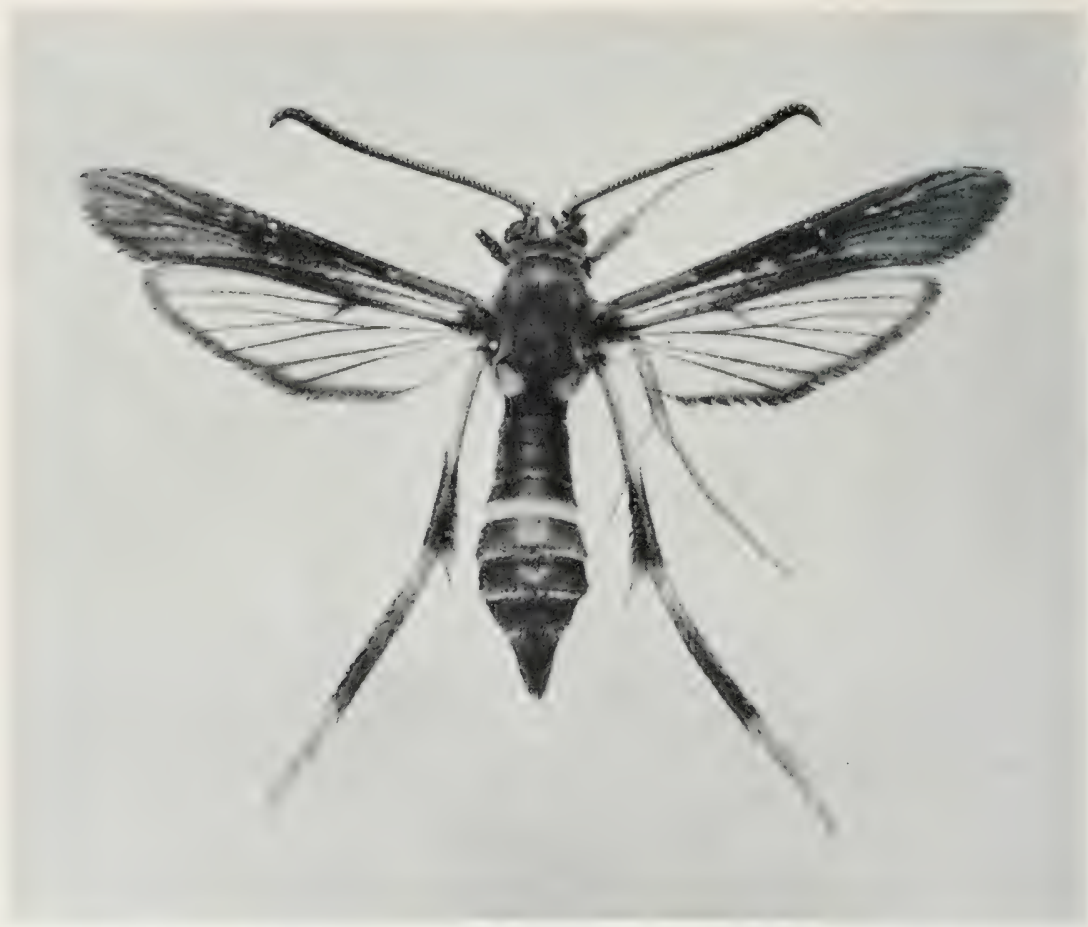

Fig. 4.-Ash borer: adult (museum specimen). The female adult, a clear-winged moth, deposits eggs on the bark of a tree. Upon hatching, the young borers penetrate the bark and bore into the wood.

tain ash. The adult, a moth with transparent rear wings, deposits eggs on the bark of the tree. The white larvae eat through the bark, penetrating the harder wood to the center of some branches. In the fall, when nearly full grown, and almost an inch long, the borer works toward but not completely through the bark. Here it digs a sort of cell in which it passes the winter. Pupation occurs in the spring, and moths emerge in May and June.

Control Measure 4 (end of circular).

Oystershell Scale, Lepidosaphes ulmi (L.), fig. 5.-The oystershell scale is inconspicuous, but it can be detected by careful examination of the limbs and branches it infests. Each scale protects itself by a light to dark brown oystershell-shaped covering about one-eighth inch long. It feeds by sucking plant sap through a threadlike beak. Dense populations of this insect cause severe damage to many kinds of trees and shrubs. 
a web, which they enlarge to take in fresh foliage as needed. They do not consume the leaves entirely but skeletonize them to such an extent that they curl, dry up, and eventually die.

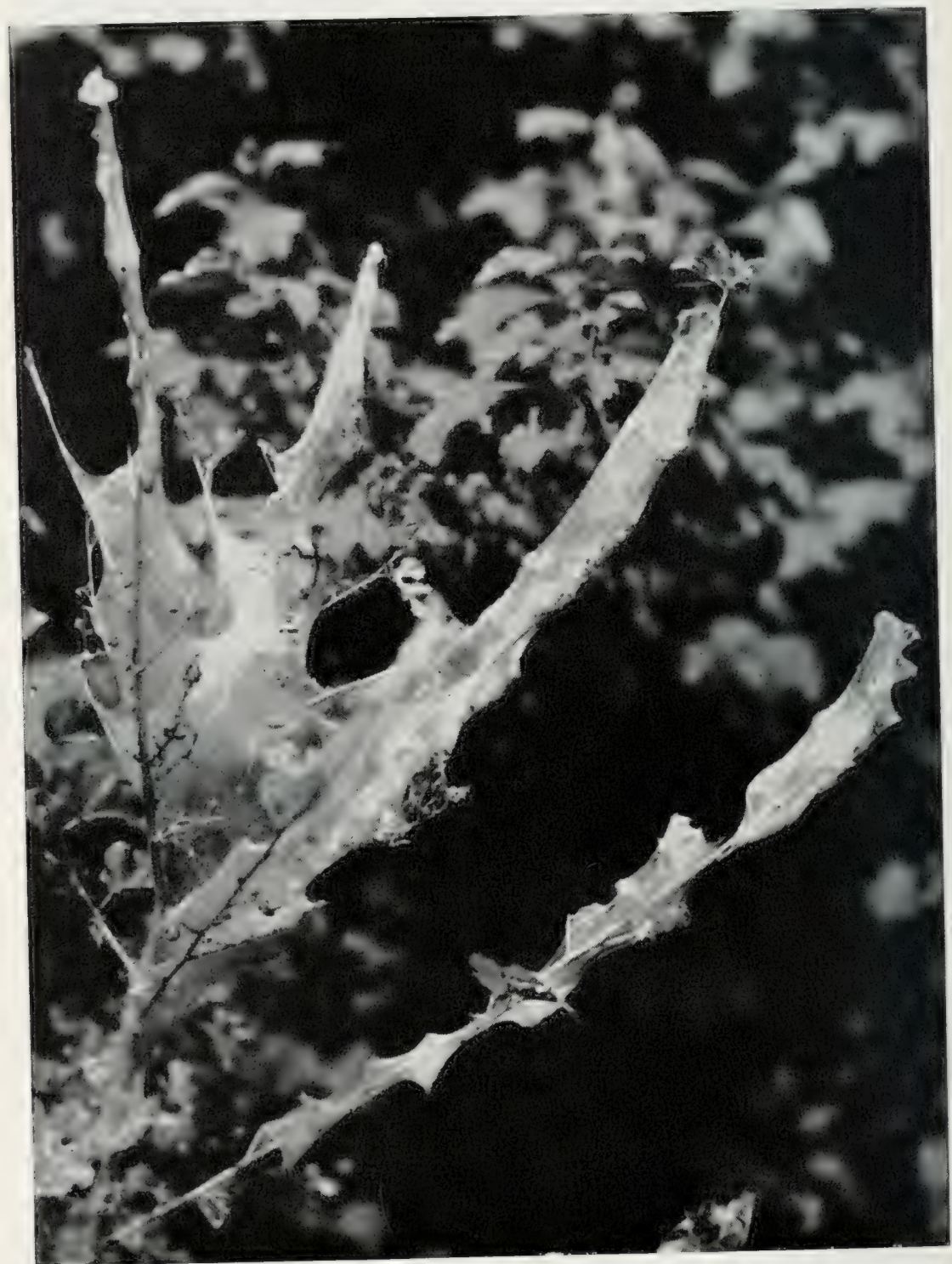

Fig. 6.-Fall webworm: tent and damage. The tent or webbing contains a colony of pale green, or yellow, hairy caterpillars that feed on foliage of the host tree. 
Pale green or yellow in color, each with a dark stripe down the back and a yellow stripe along each side, the caterpillars do not leave the web until nearly full grown. At this time they move in many directions and feed on almost any green foliage available. When mature, they move to the ground to pupate under sheltering debris or just below the surface of the soil.

Control Measure 1 or 6 (end of circular).

\section{BIRCH}

Bronze Birch Borer, Agrilus anxius Gory.-Widely distributed and a serious pest of birch trees in the open, especially white birch, the three-fourths-inch long, white, flattened, and footless grub of this species attacks all parts of the birch above ground, burrowing under the bark and causing the bark to loosen and separate from the wood. The slender bronze beetle that develops from an overwintering grub cuts semicircular holes through the bark and emerges in early spring. The female lays white eggs in bark crevices. Larvae hatching from the egirs penetrate the bark, feed, and grow to develop another generation.

Control Measure 4 (end of circular).

Birch Skeletonizer, Bucculatrix canadensisella Chamb.Unlike the bronze birch borer, which prefers trees in the open, the larva of this insect prefers woodland trees for its periodic attacks. Tiny caterpillars hatch from eggs placed singly on a leaf by the very small female moth, which is seldom seen. Each caterpillar bores directly into the leaf tissue, mines the leaf for a few weeks, and then skeletonizes the leaf on the under side before dropping to the ground to pupate for the winter. The most extensive damage by this insect is likely to occur in August.

Control Measure 1 or 2 (end of circular).

\section{BOXELDER}

Boxelder Bug, Leptocoris trivittutus (Say), fig. 7.-The adult form of this species is a black and red bug that feeds through a long, slender beak on the leaves and seed pods of the boxelder tree. It does little damage to the tree, but it creates a nuisance by congregating in great numbers about the tree and by migrating to nearby dwellings in the fall in search of winter 


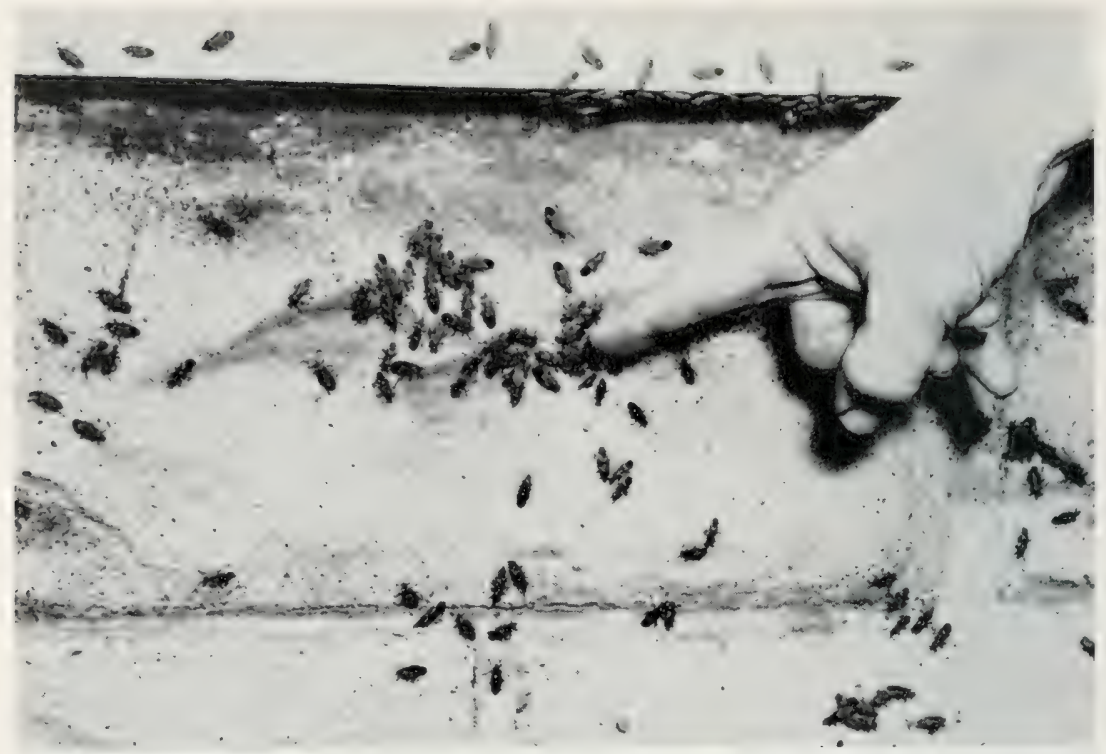

Fig. 7.-Boxelder bug: adults. Shown here are boxelder bugs on the foundation of a building. The bugs, which are black and red in color, are of no consequence as pests of boxelder trees, but they are nuisances in and on buildings.

quarters. Following hibernation, the female lays small red eggs in bark crevices. The red-bodied, black-legged nymphs that hatch from the eggs reach the adult stage through a series of molts.

\section{Control Measure 7 (end of circular).}

Boxelder Aphid, Periphyllus negundinis (Thos.).- This is a pale green, hairy plant louse that occasionally develops in great numbers. An infestation by this aphid causes some injury to the infested tree and creates a nuisance by covering sidewalks and other objects beneath the tree with honeydew. Black eggs are deposited by the female on branches in the fall. The eggs hatch in the spring, and young aphids congregate on the new buds, from which they withdraw plant juices through their slender beaks. With the ability to develop several generations within a few weeks, these aphids can soon become abundant.

Control Measure 3 (end of circular).

Eastern Tent Caterpillar, Malacosoma americanum (F.), fig. 8.-Although black cherry, chokecherry, and apple are favorite hosts, ravenous caterpillars of this species in the 


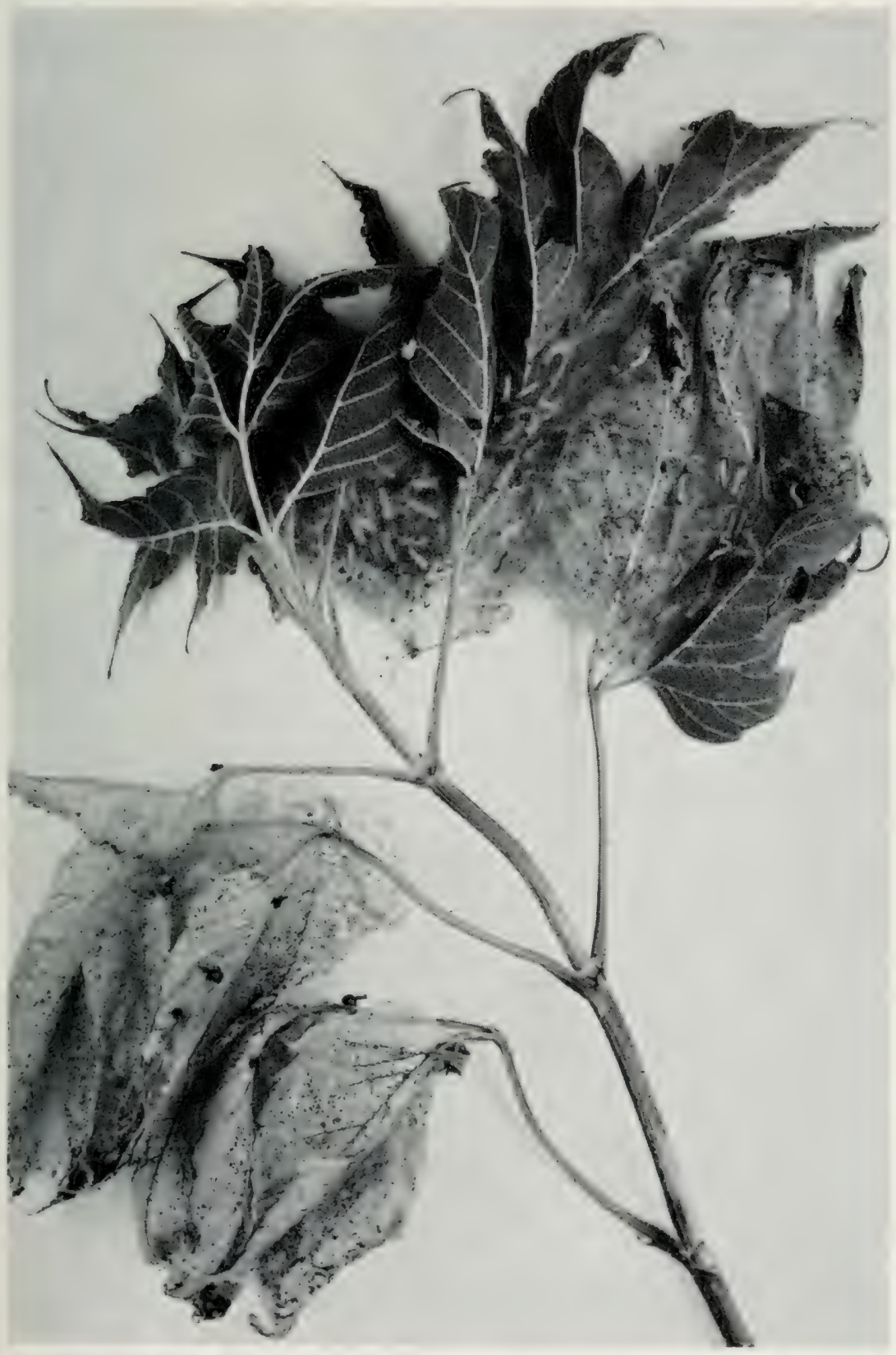

Fig. 8.-Eastern tent caterpillar: larvae and damage to boxelder foliage. The female adult, a moth, lays a batch of eggs on a twig to produce a colony of hairy caterpillars with black heads. 
spring construct tents in a wide variety of trees, including boxelder, elms, maples, and oaks. The black, hairy caterpillars hatch in March from an overwintering mass of eggs plastered to a twig in a brown band or collar. Caterpillars usually select a fork of a branch for the construction of a tent. They leave the tent to feed during the day but return at night. After feeding for 5 or 6 weeks, each caterpillar spins a cocoon on a tree trunk or in some other protected place, where it pupates. The adults, redclish-brown moths, emerge in early summer. The female lays at batch of eggs on a twig. This insect produces only one generation a year.

Control Mcasure 1 or 2 (end of circular). Although this pest usually is kept under control by natural enemies, sprays may occasionally be needed to prevent damage to valuable shade trees.

\section{BOXWOOD}

Boxwood Leaf Miner, Monarthropalpus buxi (Lab.).-Damagre by this insect is indicated in early summer by small blotches on the leaves of boxwood. Later the blotches enlarge to blisters that cause the leaves to turn brown and to drop. The small yellowish-green maggots or larvae of this species feed on the tissue in the leaf during the summer and again in the spring before the orange-yellow midges develop and emerge from the pupae. The female deposits eggs in May for a new generation.

Control Measure 8 (end of circular) about May 15.

\section{CATALPA}

Catalpa Sphinx, Cerutomia catalpae (Bdv.), fig. 9.-A ravenous feeder consuming great quantities of catalpa foliage, the caterpillar of the sphinx moth may vary in color from pale yellow with green markings to almost black. The caterpillar. has a black, hornlike process at its rear end. When grown, the caterpillar is about 3 inches long.

Emerging from an overwintering pupa in the soil, the female of this moth mates and lays hundreds of eggs in white masses on the under sides of leaves. The young caterpillars feed in groups at first, but work individually later, consuming entire leaves. 


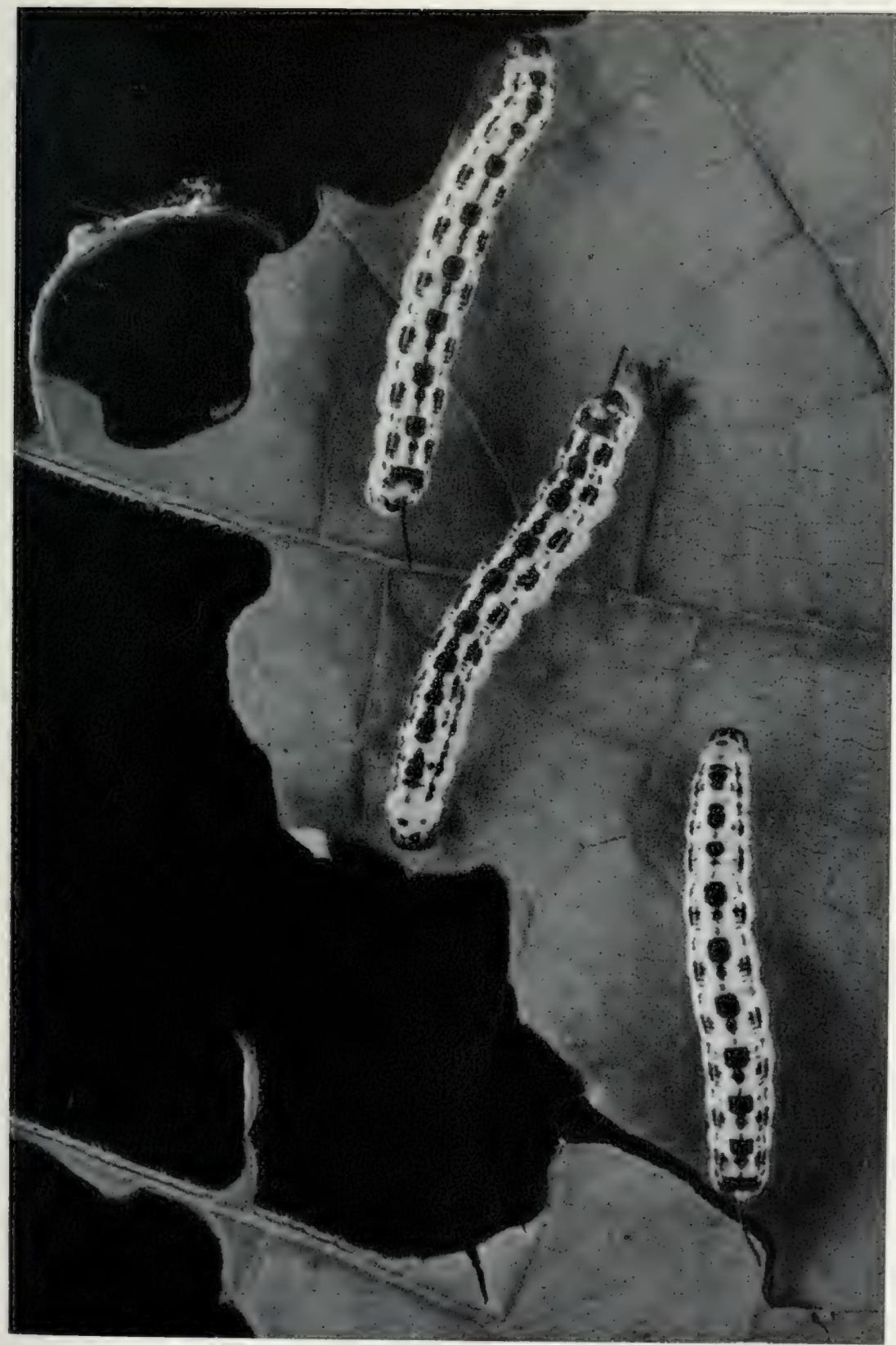

Fig. 9.-Catalpa sphinx: larvae on a catalpa leaf. The handsome caterpillars are ravenous feeders on catalpa foliage. About 3 inches long when grown, each caterpillar has a black hornlike process at the rear end. 
Control Measure 1 or 2 (end of circular). Some people grow catalpa trees mainly to raise caterpillars for fish bait, but most tree lovers want to protect their trees from these caterpillar's.

Comstock Mealybug, Pseudococeus comstocki (Kuw.).-An occasional pest of catalpa, the Comstock mealybug is likely to be found in cottony masses at the forks of tender shoots or at the bases of leaves. The male, which has wings, is seldom seen. The female, a wingless, slow-moving insect, when grown is about one-fourth inch long and elliptical in shape; she has a fringe of short, soft spines and is covered with "mealy," white wax. A sucking insect like the aphid, the mealybug likewise secretes honeydew, which supports a sooty mold.

The mealybug's yellow eggs, found in crevices of bark, are covered with a cottony mass of wax. When leaves appear on catalpa trees in spring, the eggs hatch, and the young mealybugs move to likely places to feed and grow. This insect may produce several generations a year.

Control Measure 3 (end of circular) applied with force.

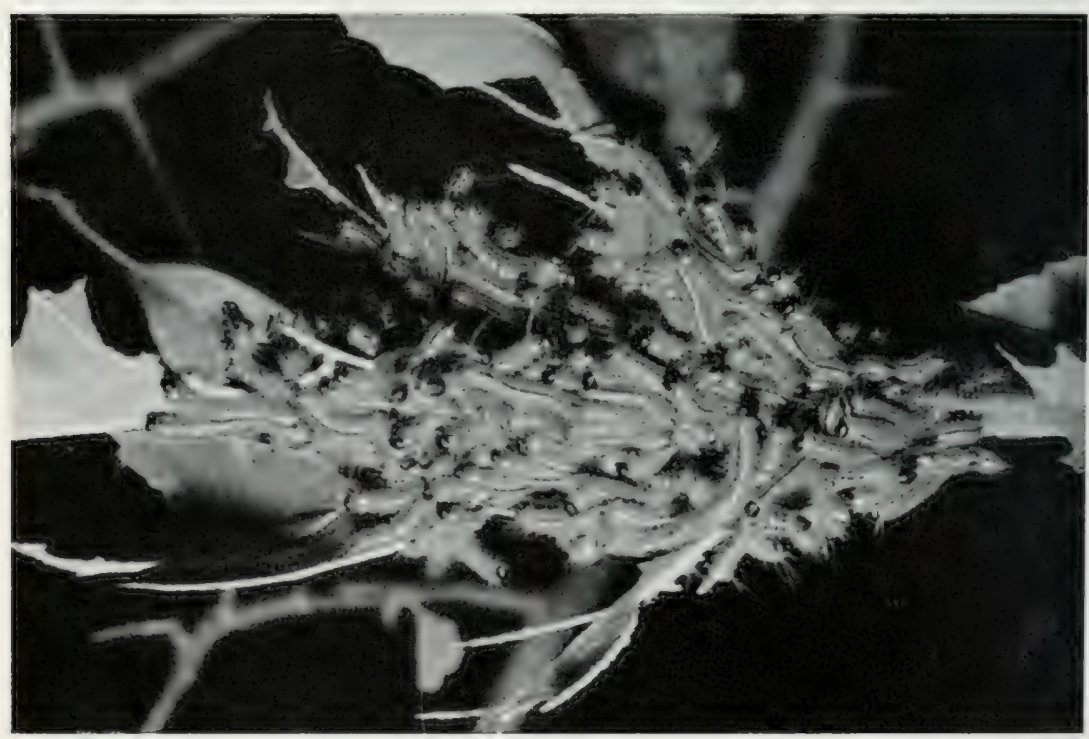

Fig. 10.-Yellow-necked caterpillar: larvae on small branch of hawthorn. When disturbed, these caterpillars rear up at both ends. Reddish when young, each caterpillar has a black head and four yellow stripes along each side of its body. A grown caterpillar is easily recognized by its yellow neck and its black body, which is covered with long, white hairs. 


\section{CRABS AND HAWTHORNS}

Yellow-Necked (aterpillar, I)atana ministra (Drury), fig. 10.-While seeming to prefer the foliage of apple and other fruit trees, the larva of this species finds nothing distasteful about the foliage of ornamental crabs and hawthorns wherever these plants are grown. Reddish in color when young, the ugly, fuzzy

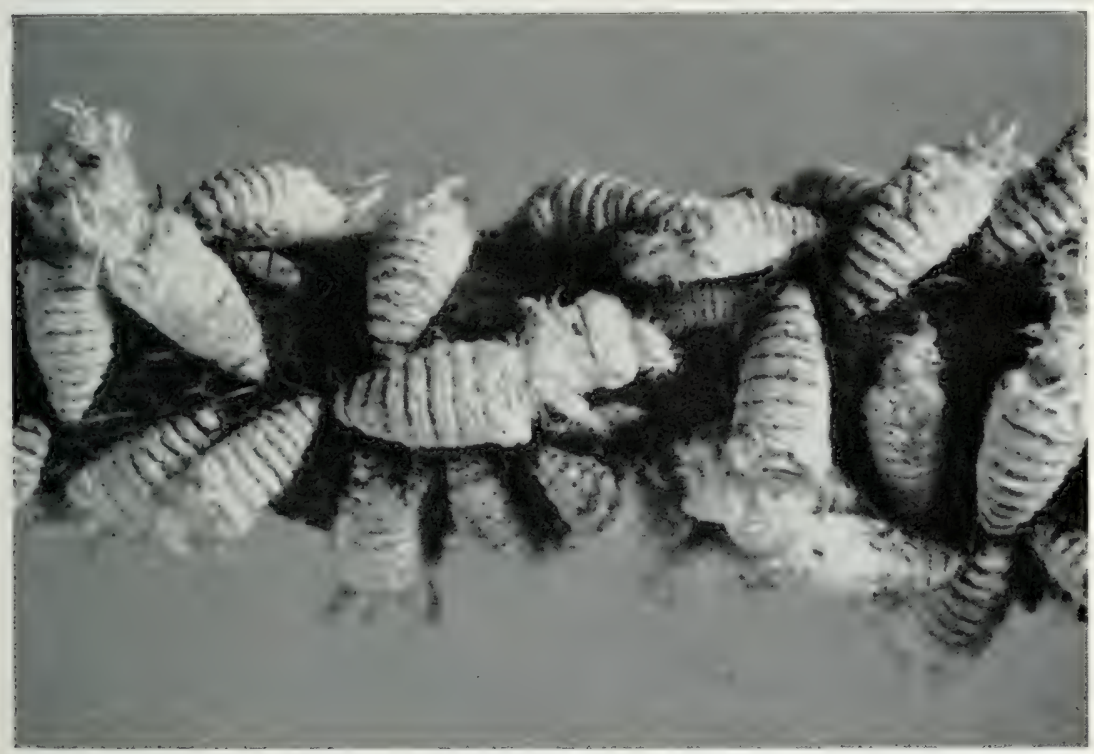

Fig. 11.- Woolly hawthorn aphid: infestation on hawthorn twig. The aphids, which are white in color, have sucking mouthparts.

caterpillar has a yellow neck. It has a black head and four yellow stripes along each side of its body. Caterpillars of this species feed ravenously in groups, but, when disturbed, they stop feeding and rear up at both ends. When fully grown, each caterpillar drops to the ground, burrows in a short way, and pupates. The adults, or moths, appear in early summer, and at about this time the female deposits eggs in clusters on the under sides of leaves.

Control Measure 1 or 2 (end of circular) when caterpillars are small.

Woolly Hawthorn Aphid, Erinsoma crataegi (Oest.), fig. 11. -Occurring in dense colonies on twigs and branches, the white, restless plant lice of this species are conspicuous. They may 
cause considerable damage to the hawthorn, distorting leaves and shoots by their removal of plant juices. The life history of this aphid is probably a complicated one and is not well known.

Control Heasure os (end of circular) applied with force.

European Red Mite, Metatetranychus ulmi (Koch).-Leaves of hawthorn or crab lacking a glossy, green appearance and having a somewhat blanched, or brown, dry look and a tendency to curl are signs of damage produced by hundreds of tiny red mites of this species feeding on both leaf surfaces. Brick red in color, the adults of the European red mite are scarcely the size of pinheads. They have bristle-like hairs curving backward over their robust, globular bodies. The female deposits her eggs, which look like tiny cherries, in great numbers on both leaf surfaces. Development of the mite occurs through a series of molts. The white, discarded molt skins of a great number of young mites make infestations conspicuous. Rasping of the leaf surfaces and withdrawal of chlorophyll and plant juices cause serious damage to the plants infested.

Control Measure 9 (end of circular).

San Jose Scale, Aspidiotus perniciosus Comst., fig. 12.Probably the best known of the scale insects, San Jose scale is widely distributed and is a serious pest on many trees and shrubs. Heavy infestations encrust limbs and branches, causing them to die. Scraping an infested branch with a thumb nail or a knife squeezes the yellow juice from the saclike insects beneath the gray to black, circular shells, each about one-sixteenth inch

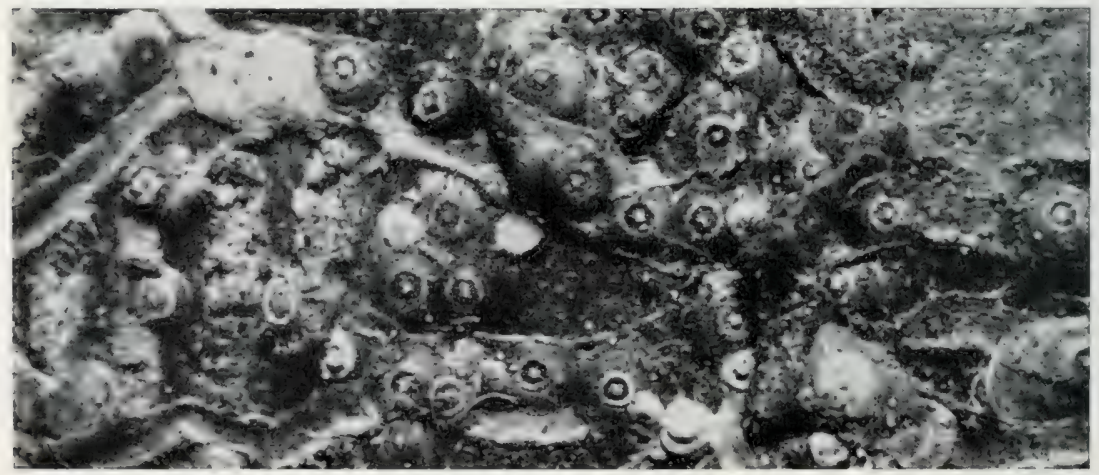

Fig. 12.-San Jose scale: infestation on bark of tree. A yellow saclike insect is beneath each circular shell shown here. The shells are each about one-sixteenth inch in diameter and gray to black in color. 
in diameter. The female overwinters as a partly grown insect and reaches maturity in early spring. After mating, she gives birth to living young: small, flat, yellow creatures, which crawl out from under the mother shell. When a crawler finds a suitable place, it settles down, inserts its threadlike beak into the bark tissue, loses its legs and antennae, and starts making a shell for its own protection. As the scale grows, its shell is enlarged and, following a series of molts, the scale reaches maturity. The fragile male scale develops wings and escapes from its protective shell to mate with a female, which does not leave its shell. The San Jose scale may produce several generations in a summer.

Control Measure 5 (end of circular) on dormant plants.

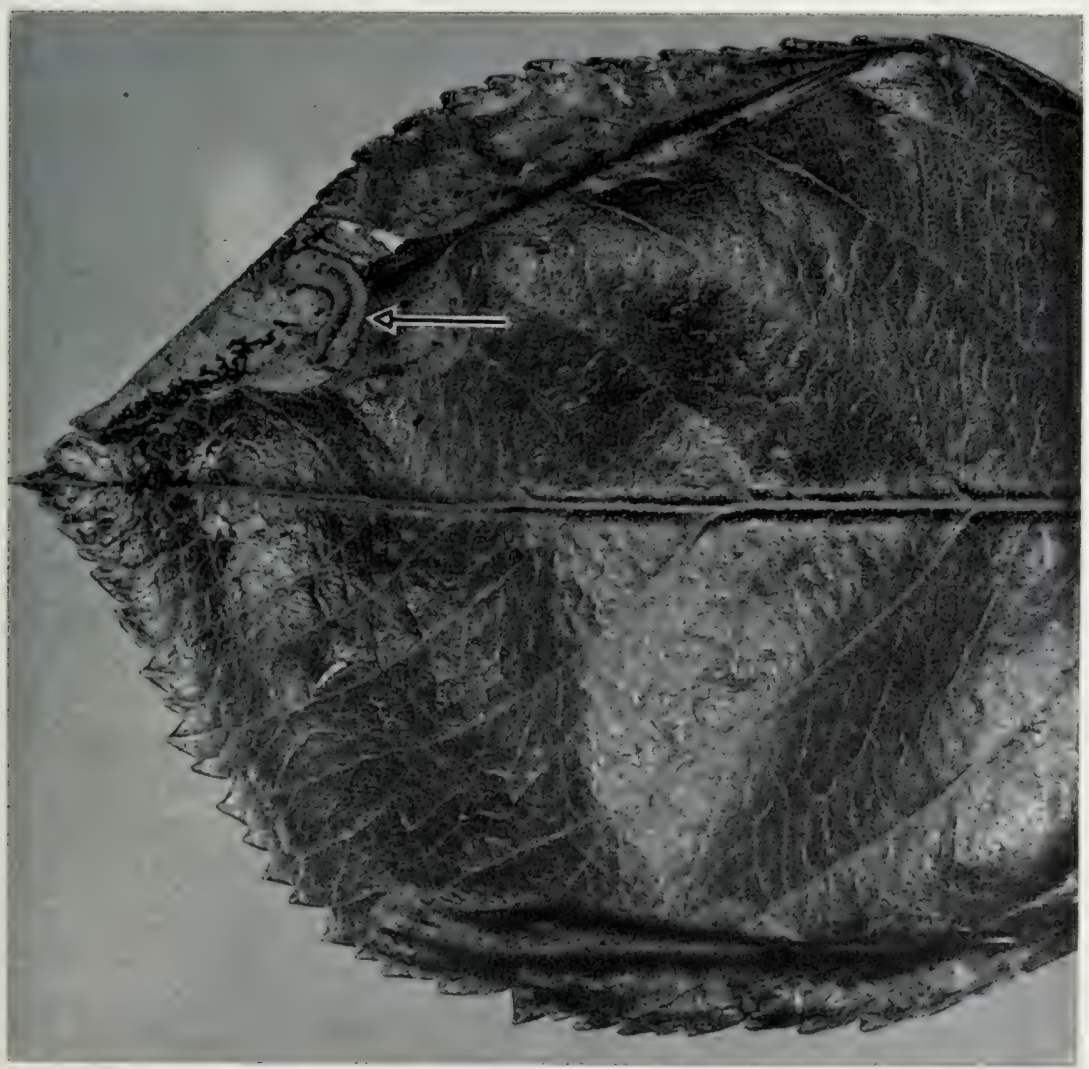

Fig. 13. - Hawthorn leaf miner: larva and damage to hawthorn leaf. The upper epidermis along one margin of the leaf is folded back to disclose the white larva (arrow) and its excrement. Along the opposite margin of the leaf is a dark blister, a sign of damage by the leaf miner. 
Hawthorn Leaf Miner, Profemusa canadensis (Marlatt), fig. 13.-Conspicuous dead areas that may include a fourth to half of a leaf at the tip or side indicate damage by the leaf miner. The adult is a sawfly, a beelike insect, that emerges from an overwintering pupal case in the soil and deposits eggs in the tissue of unfolding leaves in May. The eggs, which may number 1 to 5 per leaf, produce larvae that mine the leaves. About 2 weeks after hatching, each larva makes a hole in the leaf and drops to the ground, where pupation and hibernation occur. This insect produces one generation a year.

Control Measure 10 (end of circular) just as soon as the leaves are fully expanded. Spray applications earlier or later are ineffective.

\section{DOGWOOD}

Dogwood Borer, Thamnosphecia scitula (Harr.).-The caterpillar of this species is white and it has a brown head. It is the larva of a clear-winged moth with a wingspread of less than an inch. Eggs deposited by the female moth on the bark of dogwood trees in May and June produce borers that eat through the bark. These borers feed just beneath the bark, often girdling limbs and small trees. The borers become full grown before winter, hibernate in their tunnels, and change to pupae in the spring.

Control Measure 4 (end of circular).

Dogwood Scale, Chionaspis corni Cooley.-Usually kept under control by natural enemies, this scale occasionally builds up dense populations that give twigs and branches a whitish appearance. The female scale is somewhat pear shaped and about oneeighth inch long; the male scale is smaller and more slender and has three ridges on the upper side. Purple eggs carry the insect through the winter.

Control Heasure 5 (end of circular) in late winter or Control Measure 3 in early summer after the eggs have hatched.

\section{DOUGLAS FIR}

Cooley Spruce Gall Aphid, Chermes cooleyi Gill., fig. 14.Douglas fir is the intermediate host for this small aphid, which splotches the needles with cottony masses of wax that protect the aphid and her eggs. Some of the aphids developing from 


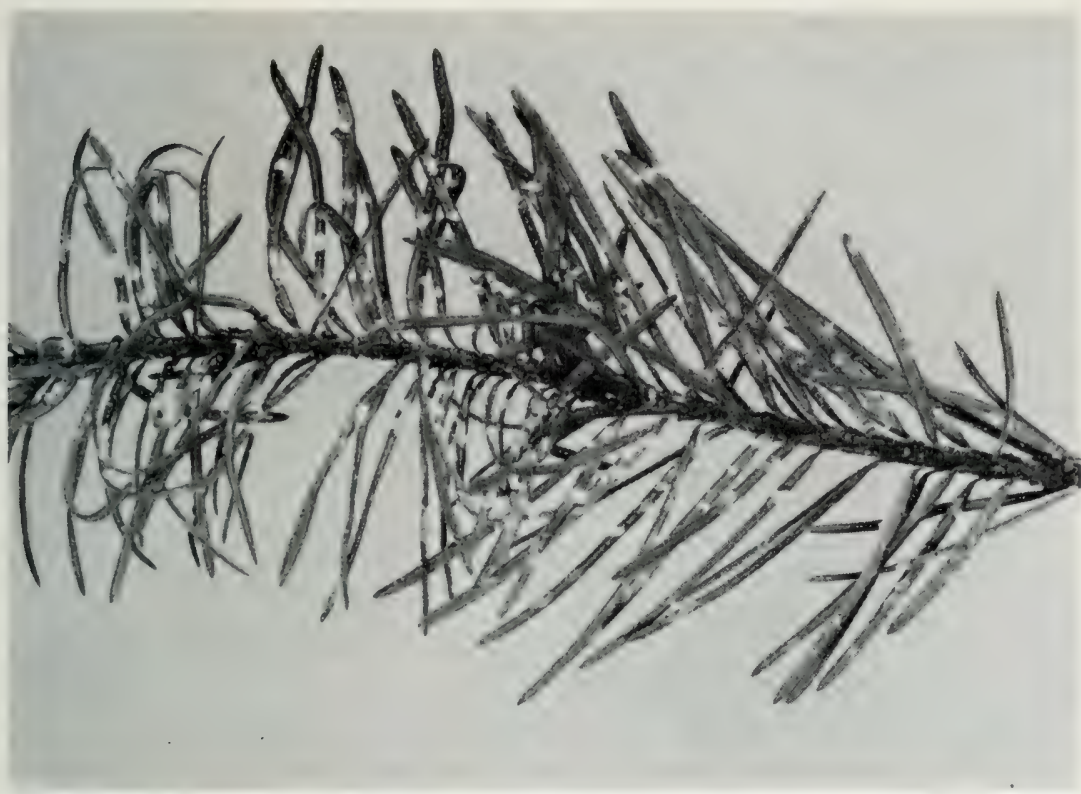

Fig. 14.-Cooley spruce gall aphid: an infestation on Douglas fir. Each white splotch on the needles represents a cottony mass of wax that protects an aphid. Beneath the wax the female lays her eggs. Some of the insects developing from these eggs have wings; others do not. Those that have wings migrate to spruce, where they produce galls at the tips of branches.

these eggs have wings and they migrate to spruce, where they produce galls. No galls develop on Douglas fir.

Control Measure 3 (end of circular) in June.

\section{ELM}

Spring Cankerworm, Paleacrita rermata (Peck), figs. 15 and 16.-The spring cankerworm is a common pest of elms and perhaps the most important leaf eater that infests the American elm in Illinois. The caterpillar, or larva, is a dark green or black "measuring worm" that does not wait for the buds to unfold before starting to feed. At first rather inconspicuous, the small raterpillar eats the tissue on one side of any leaf it feeds upon, but as it grows it punctures and later consumes all of the leaf except the large veins. By the time the caterpillar is 1 inch long. or full grown, it may be red, green, yellow, or black in color. It drops to the ground by means of a thread, burrows into the soil, and pupates. The adults emerge during warm spells in late 
winter. The wingless female climbs a nearby tree and, after mating, hides hundreds of eggs in crevices and under loose bark. These eggs hatch just as soon as the leaf buds begin to open in the spring. An elm may be partly or completely stripped of its foliage by spring cankerworms.

Control Heasure $1 \mathrm{or}^{2}$ ( (end of circular) as soon as leaf buds begin to open in spring, when the worms are still small.

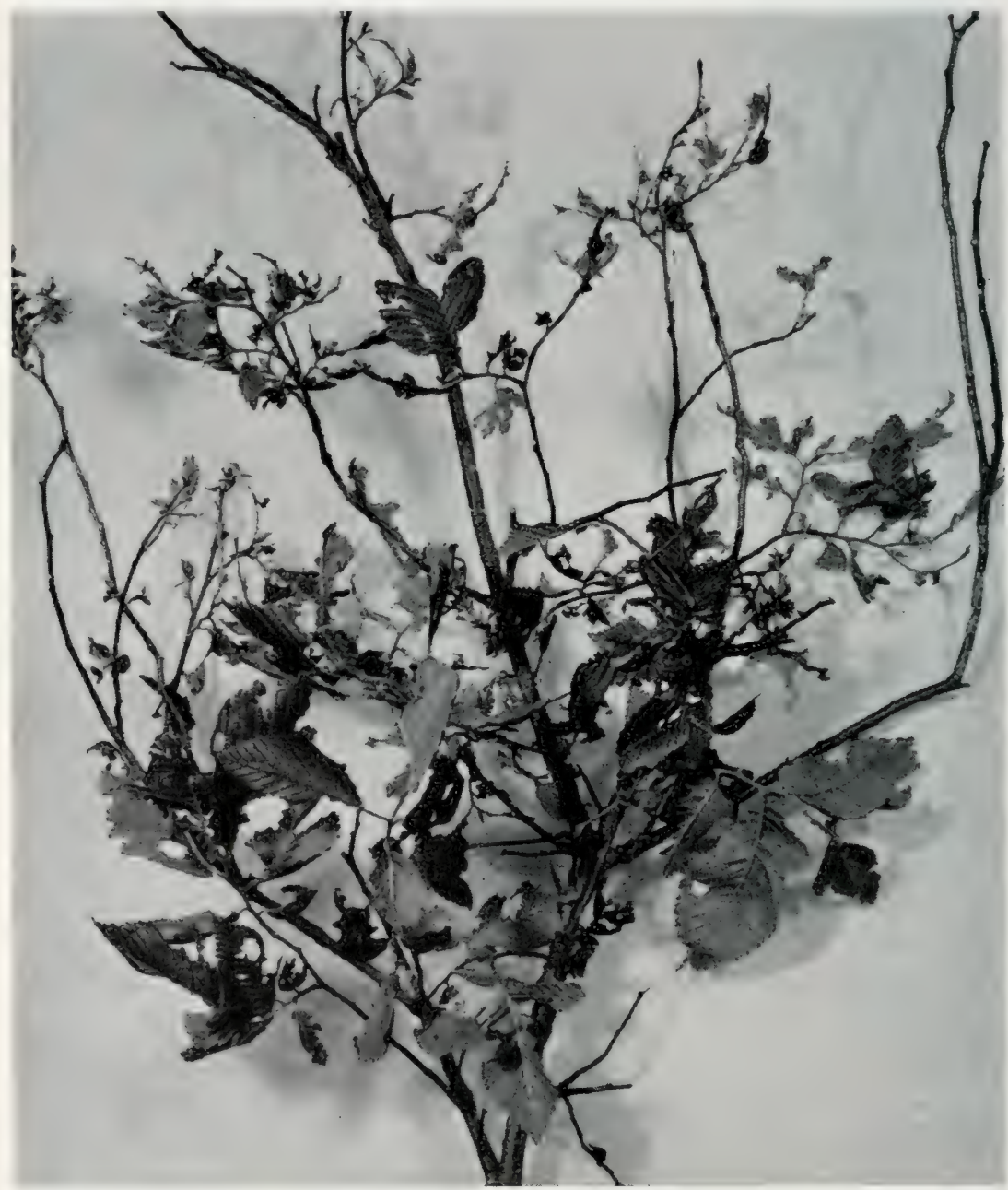

Fig. 15.-Elm foliage damaged by spring cankerworms. The dark green to black "measuring worms" begin feeding before leaf buds are completely open. 
White-Marked Tussock Moth, Hemerocampa leucostigma (J. E. Smith), fig. 17.- Second in importance to the spring cankerworm as a leaf eater of American elm, this insect in its larval stage is mainly a pest of city shade trees. The showy caterpillar of the tussock moth begins feeding a little later in the spring than the cankerworm but may develop two generations in a year to make up for the late start. Its body is covered with tufts

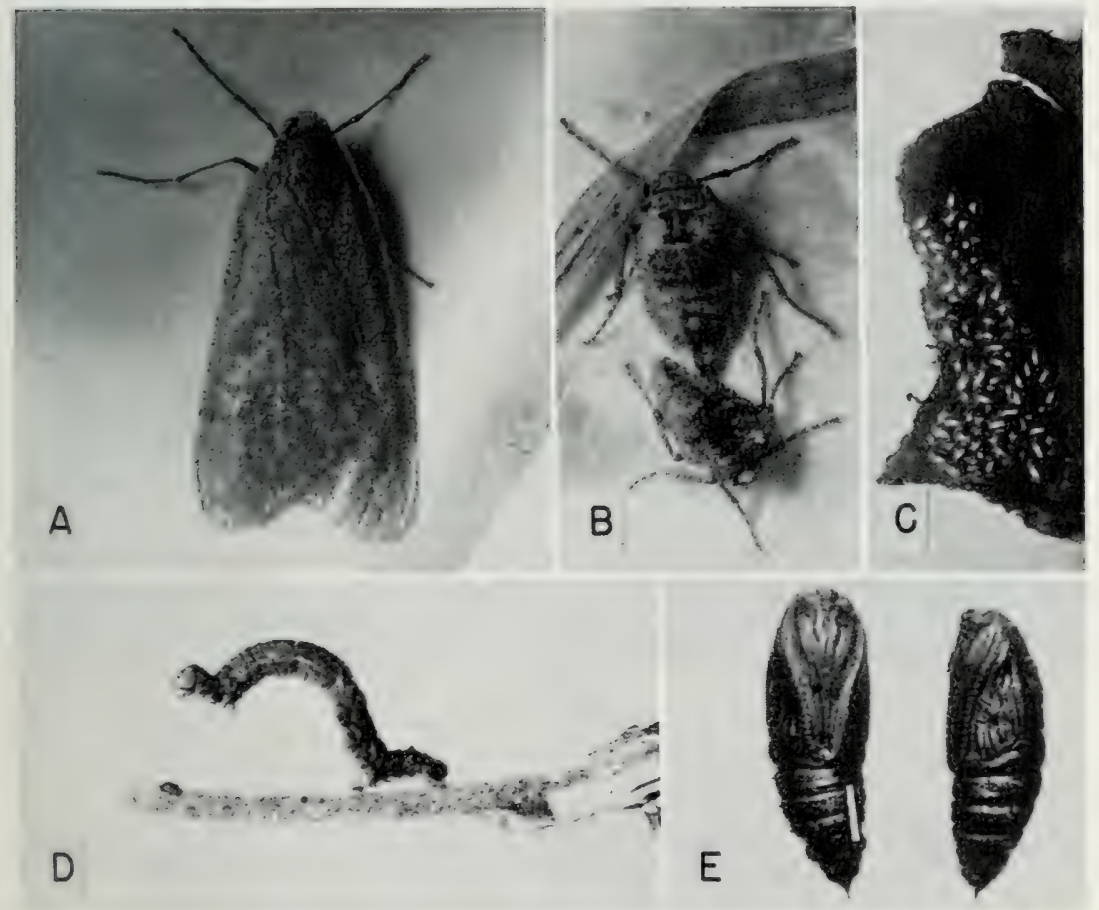

Fig. 16.-Spring cankerworm: $A$, male adult; $B$, female adults (wingless); $C$, eggs; $D$, larra; $E$, pupae. The larva is dark green, brown. or black. (I'hotographs from ['nited States Department of Igriculture.)

of long white hairs. Two longer tufts of black hairs provide "horns" at the front, while a single black tuft "flags" the rear. When 5 or 6 weeks old, the caterpillar stops consuming leaves and spins a cocoon on the trunk or a limb of the tree on which it has been feeding, or on a fence or house. Here transformation takes place. From the cocoons emerge winged males and wingless females. A wingless female, after emerging and mating, lays several hundred white eggs, all glued together in a clump, 


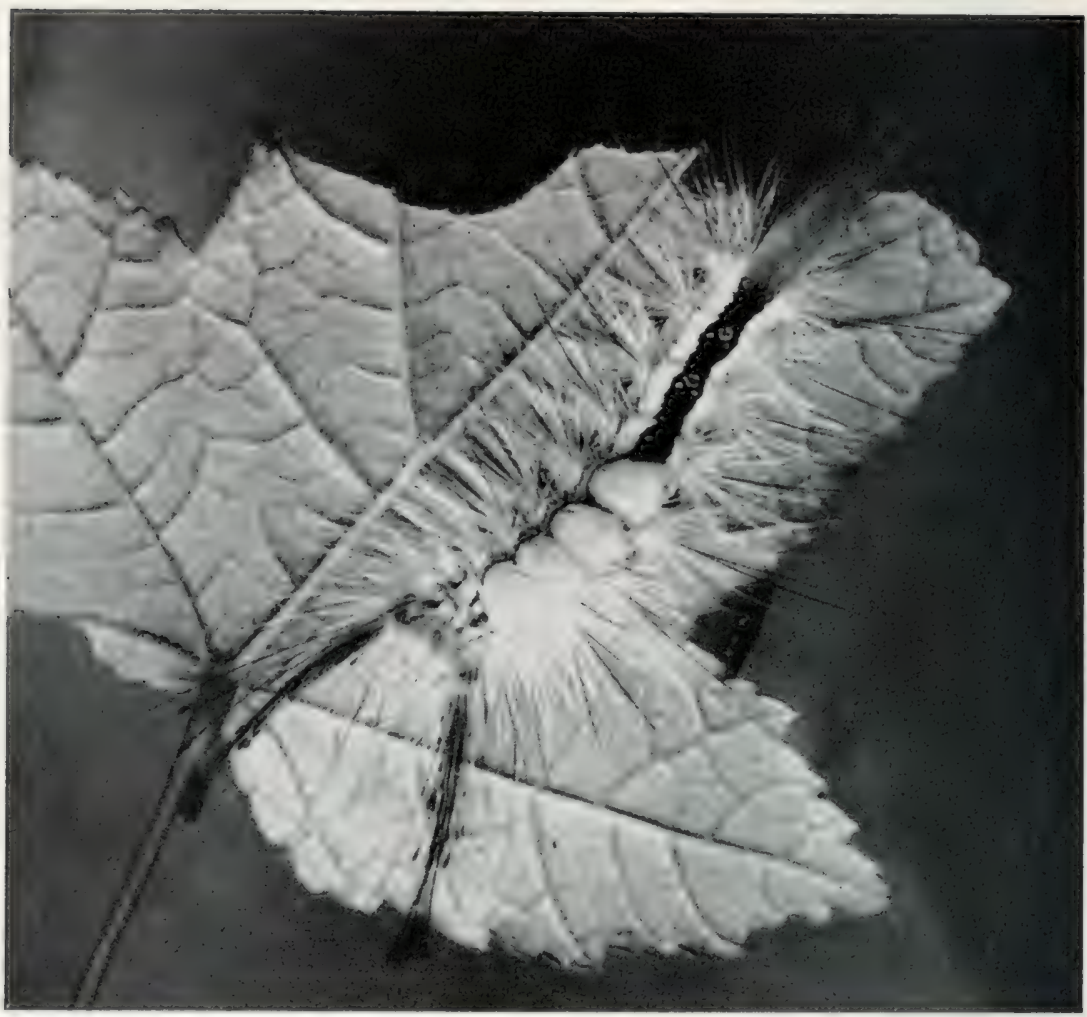

Fig. 17.-White-marked tussock moth: caterpillar, or larva, on leaf. This caterpillar is hairy; it has a red head, and its body is strikingly colored with yellow, black, red, and white.

on the empty cocoon. Newly hatched caterpillars skeletonize the leaves and consume all but the large veins.

(omtrol Measme $1 \mathrm{or}^{\circ}$ ' (end of circular). Obviously, sprays applied while the insect is in the cocoon and egg stages are ineffective.

Fall Webworm, fig. 6.-See under Ash. Comtiol Measure 1 or 6 (end of circular).

Elm Leaf Beetle, Galerucella ionthomelacna (Schr.), fig. 18. - Another ravenous leaf eater and a particular pest of Chinese elm, the larva or grub of the elm leaf beetle skeletonizes the leaves, causing them to dry out, curl, and drop prematurely. An ugly, almost black, spiny grub hatches from each of the yellow, spindle-shaped eggs placed by the female beetle in small 

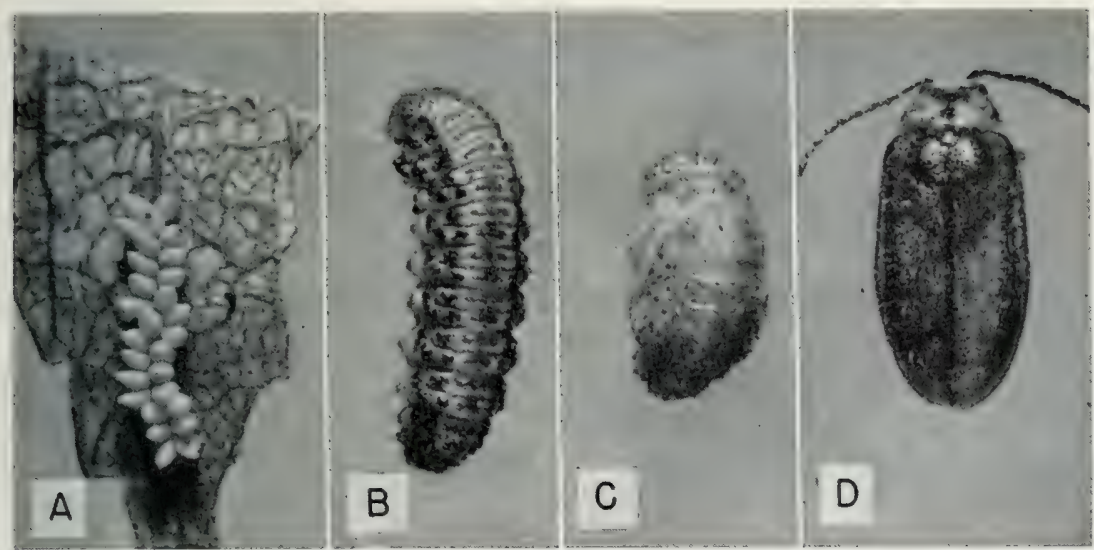

Fig. 18.-Elm leaf beetle: $A$, eggs; $B$, larva; $C$, pupa; $D$, adult. Ihoth larva and adult feed on foliage. The eggs are yellow and spindle shaped; the larra is spiny and almost black; the adult, about one-fourth inch long, has a yellowish to green body and yellowish legs and antennae.

groups on the under sides of the leaves of an elm tree about the time the leaves become full grown. When through feeding, the grub drops or crawls to the ground near the base of the tree, pupates, and transforms to the adult stage to start another generation. The adults hibernate in barns, sheds, and dwellings, where, if present in large numbers, they sometimes become a

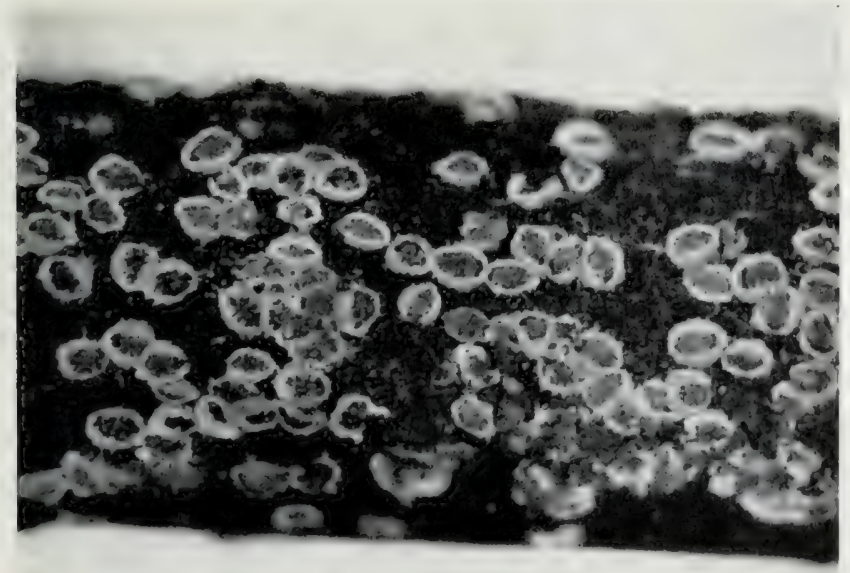

Fig. 19.-European elm seale: an infestation on an elm twig in spring. Each scale has a reddish center and a white fringe. 
nuisance. Each beetle is about one-fourth inch long; it has yellowish legs and antennae and a yellowish to green body. It chews small holes in the foliage. The female beetle lays 400 to 800 eggs, which hatch in about a week.

Control Measme 1 or 2 (end of circular) about the time leaves are grown or as soon as damage is observed.

European Elm Scale, Gossyparia spuria (Mod.), fig. 19.Although inconspicuous, like other scale insects, the European elm scale occurs in dense populations and sucks great quantities of sap from any tree it infests. Some of the sap is secreted as honeydew, on which a sooty mold may grow.

The immature scale, which overwinters on a limb or branch or in a crotch of an elm, is about one-tenth inch long, oval, reddish-brown in color, and has a white fringe. The male completes development in a white cocoon. The female changes little from the overwintering form. In early summer, she lays eggs on a limb or branch. Hatching in an hour or so, the young scales move in great numbers to the under sides of nearby leaves, where they settle and feed until late summer. Many migrate back to a limb or branch to hibernate, but some are lost when the leaves drop in autumn.

Control Heasure 5 (end of circular) in late winter or Control Measure 3 in June.

Scurfy Scale, Chionaspis furfura (Fitch), fig. 20.-Widely distributed and a pest of fruit and shade trees in addition to elm, the dirty white, pear-shaped scale of this species is about oneeighth inch long. Infestations of this scale are more conspicuous than the infestations of some other scales, especially when they are dense enough to give the infested bark an ugly appearance. Withdrawal of sap from a tree by an infestation of this scale reduces the vitality of the tree, kills branches and limbs, and sometimes, if the tree is young, deforms it.

The purple eggs, which carry the insect through the winter, begin hatching toward the last of May, giving rise to tiny purple crawlers that move away from the mother's shell. The crawlers soon settle on the bark to feed and to make shells of their own. The scale covering of the female is broad, while that of the male is narrow and has three longitudinal ridges. This scale may produce two generations a year in the southern half of Illinois, but usually it produces only one generation a year in the northern half of the state. 


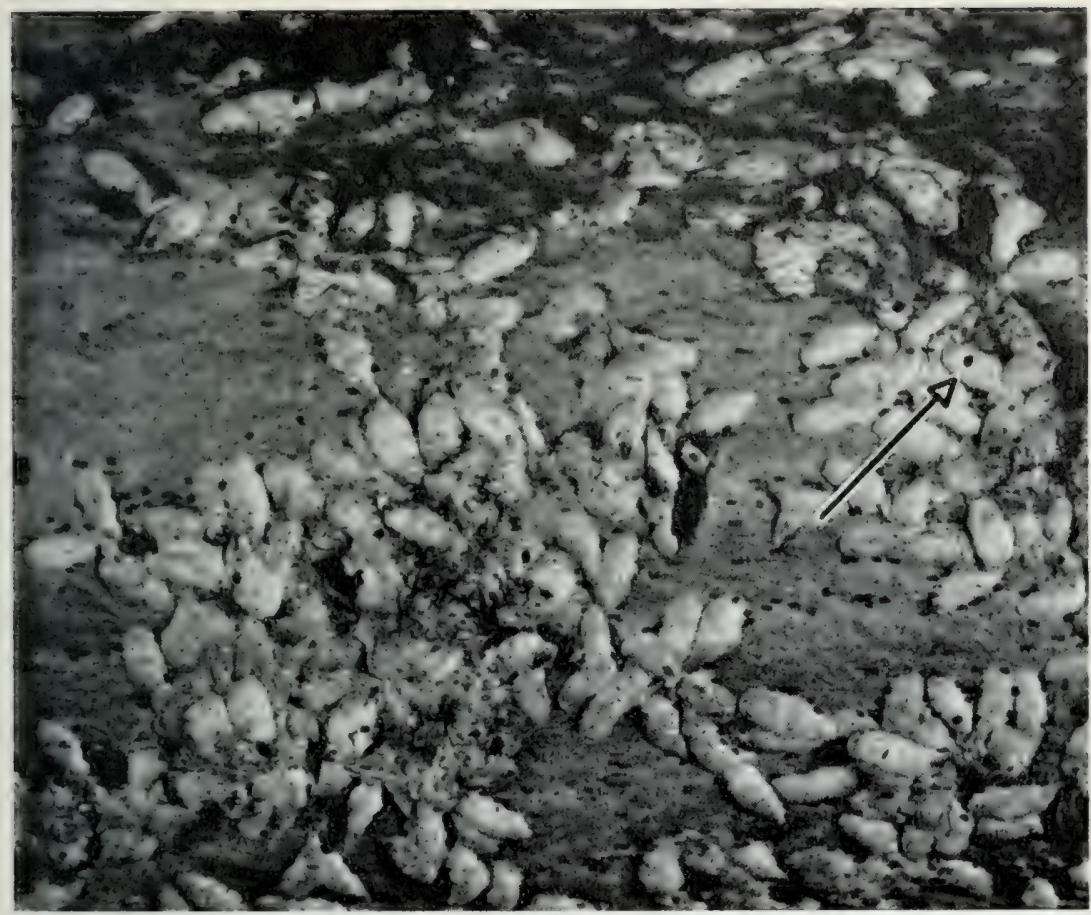

Fig. 20.-Scurfy scale: an infestation on an elm twig. The scales are gray and somewhat pear shaped. The overwintering eggs under the shells are purplish. The hole made in one scale by an emerging parasite is indicated by an arrow.

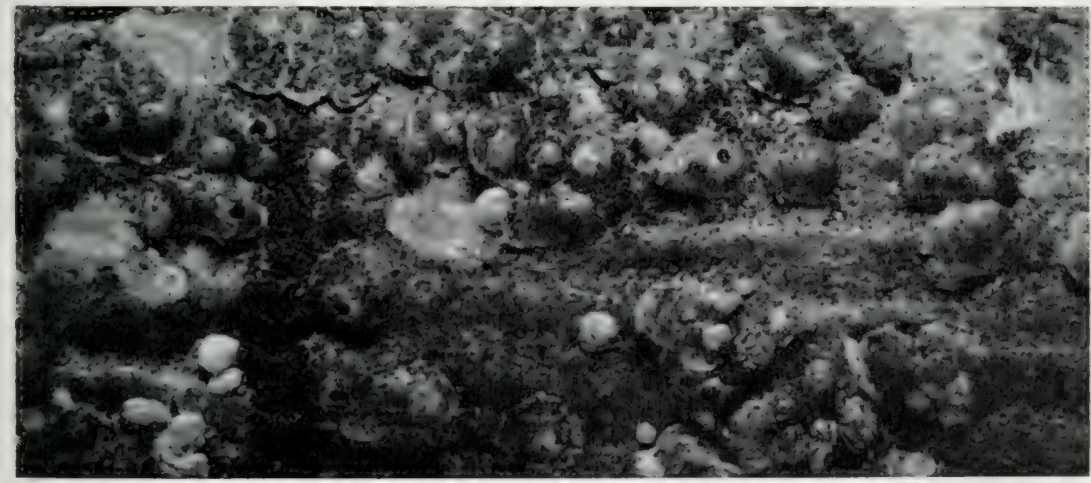

Fig. 21.-Putnam scale: an infestation on an elm twig. The covering or shell of the female scale is almost circular and about one-sixteenth inch in diameter; that of the male is oblong. Near the center of each shell is a brick-red nipple that contrasts with the dark gray or black remainder of the shell. The scale insect beneath the shell is yellow. 
('ontrol Heasure s) (end of circular) applied in late winter, or control Heasure 3 applied after eggs have hatched and while scales are still small.

Putnam Scale, Aspidiotus ancylus (Putn.), fig. 21.-Ordinarily of little consequence, but a pest that may do serious damage to elms following repeated foliar applications of DDT, Putnam scale sometimes encrusts limbs and branches, causing them to die. Only about one-sixteenth inch in diameter, the female scale covering is almost circular and is cemented to the bark as a shell resembling an inverted saucer with a brick-red nipple that contrasts with the dark gray or black remainder of the shell. The shell of the male of the Putnam scale is oblong in shape.

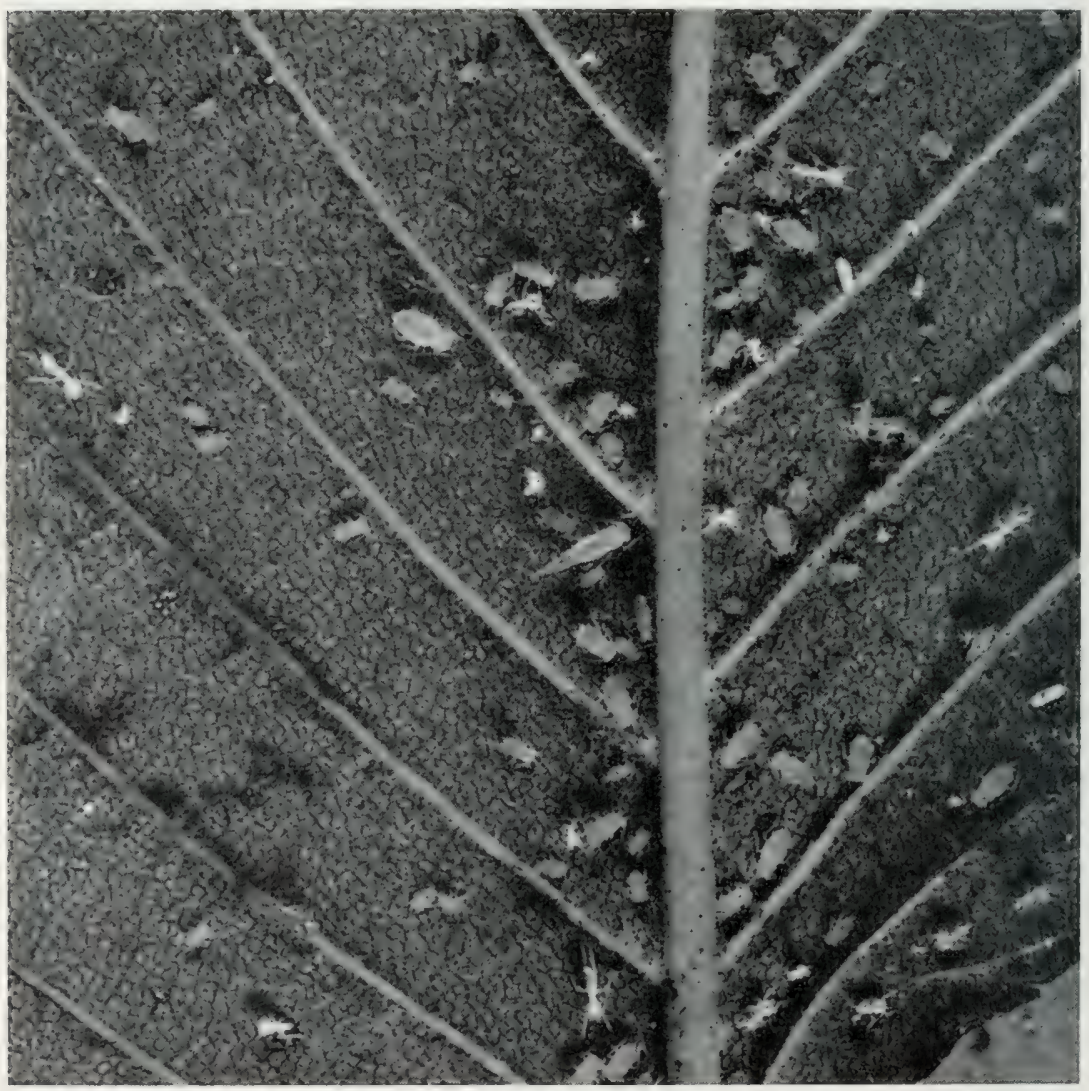

Fig. 22.-Elm leaf aphid: infestation on under side of elm leaf. The aphids are greenish and of various sizes; some have wings and some are wingless. 
The insect passes the winter as a yellow, partly grown scale beneath the shell. Development is completed in early spring, and, after mating, the female lays a few eggs a day. Egg laying and hatching extend over a period of 6 weeks or more. Some of the first-brood crawlers settle on the leaves of the elm, where development is completed; the second brood crawlers migrate back to the limbs or branches for the winter.

Control Measure 5 (end of circular).

Elm Leaf Aphid, Myzocallis ulmifolii (Monell), fig. 22.For the most part, this aphid is a nuisance pest because of the honeydew that drips on sidewalks and automobiles from the elm leaves on which the aphid feeds. Following repeated foliar applications of DDT to elm trees, infestations of this aphid increase, the secretion of honeydew increases, and some damage to infested trees undoubtedly results. Except for sooty mold that grows in the honeydew, there is no visible evidence of damage.

Both winged and wingless forms of the yellowish-green aphid, as well as white molt skins, are usually present on the under sides of elm leaves. Unlike many species of aphids, the elm leaf aphid does not migrate to another host.

Control Measure 3 (end of circular).

Woolly EIm Aphid, Eriosoma americamum Riley.-Curlerl elm leaves are signs of an infestation on the under sides of the leaves by the white, woolly, restless aphids of this species. Infestations are localized rather than general. This species overwinters in the egg stage. Eggs laid on bark hatch about the time elm leaves unfold; upon hatching, the aphids crawl to the leaves and begin to suck juices from the tissues. In June, the winged form migrates to shadbush, where it gives birth to a wingless form which, in time, produces another winged form that migrates back to elm to lay the overwintering eggs.

Control Measure 3 (end of circular).

Elm Cockscomb Gall Aphid, Colopha ulmicola (Fitch), fig. 23.--On an elm leaf, a conspicuous, unsightly growth resembling a cock's comb is a sign of this aphid. Production of each gall is stimulated by a wingless female aphid to provide a home for her family.

Control. Galls produced by aphids of this species do little damage. No control measure is recommended.

Elm Borer, Saperda tridentata Oliv., fig. 24.-Escaping sap and small masses of wet, brown frass on the trunks and limbs of 


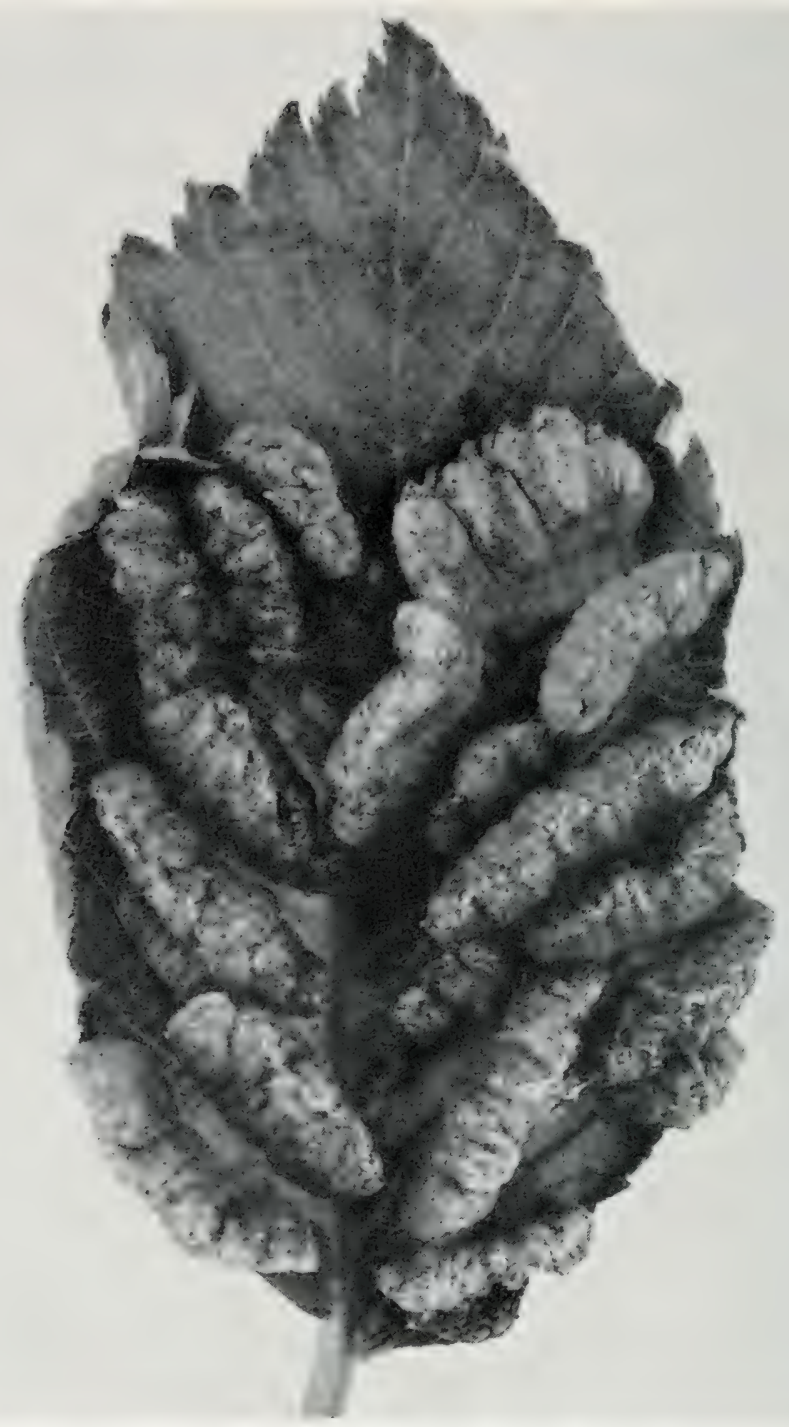

Fig. 23.-Elm cockscomb galls. Each gall contains many greenish aphids.

elms indicate the presence of larvae of this species. Probing an infested tree with a knife will disclose flat, shallow galleries running in many directions and white, legless, segmented grubs. Each larva is about an inch long when full grown. The larva pupates in May. The adult is a gray beetle, about one-half inch 
long, with three orange-colored stripes across each wing cover. The beetle cuts through the bark to escape. After mating, the female beetle deposits eggs on the bark of an elm tree. The young grubs that hatch from the eggs bore into the bark.

Control Measure 4 (end of circular).

Smaller European Elm Bark Beetle, Scolytus multistriatus (Marsh.), fig. 25.-This bark beetle is the more important of two
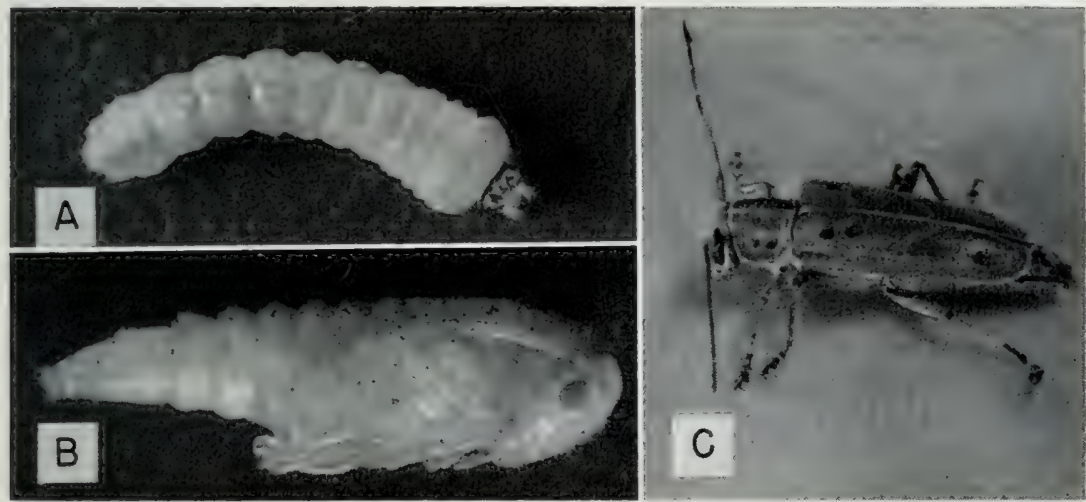

Fig. 24.-EIm borer: $A$, larva; $B$, pupa; $C$, adult. The larva, or grub, is white and legless. The adult is a gray beetle about one-half inch long that has three orange-colored stripes on each wing cover (stripes only faintly visible in picture).

species that spread the deadly Dutch elm disease in Illinois. The other is the native elm bark beetle, Hyluryopimus rufipes (Eichh.), which is rarely found in Illinois.

The white, legless grub, or larva, of this beetle passes the winter under the bark of an elm tree. It pupates in early spring and transforms to the adult, a reddish-brown beetle, which drills a small hole through the bark to escape. Thousands of "shot holes" characterize the bark of heavily infested trees. If the beetle emerges from a tree infected with Dutch elm disease, it may carry spores of the disease fungus to a healthy tree, where inoculation takes place when the beetle feeds in the crotches of small branches. After feeding in the crotches of living elms, the beetle bores into recently cut elm wood or weak and dying tree trunks or branches. The female places white, spherical eggs along the edges of a gallery she constructs for this purpose. Small, white larvae that hatch from the eggs feed between the bark and wood, producing characteristic patterns with their 


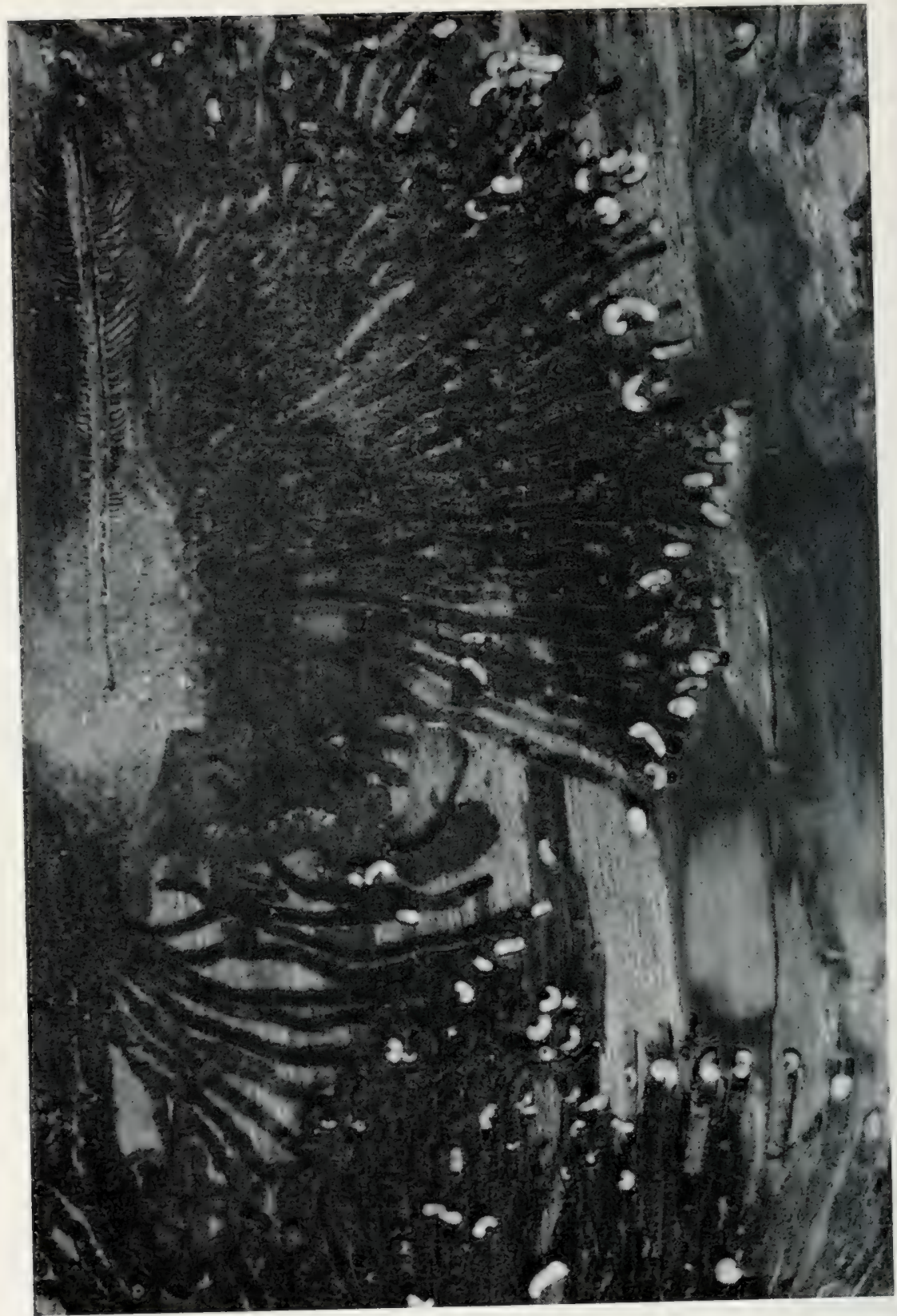

Fig. 25.-Smaller European elm bark beetle: larvae and galleries on the under side of elm bark. The adults, small, brown beetles, carry the Dutch elm disease fungus from diseased to healthy elms. 
mines. Emergence of beetles begins about the middle of May in Illinois and reaches a peak about the middle of June. A second brood of beetles which follows reaches a peak emergence in August.

\section{Control Measure 18 (end of circular).}

Banded Elm Leafhopper, Scaphoideus luteolus Van D.Rarely seen, this brown leafhopper, narrow and about one-fourth inch long, is reported to be the carrier of phloem necrosis, a serious virus disease of American elms. The eggs of this insect overwinter on the bark of elms and hatch in early spring; the young hoppers, called nymphs, feed on new foliage, producing a brown area where the sap is withdrawn. The leafhoppers themselves cause little direct damage, but the virus they carry from diseased to healthy American elms is deadly to the trees.

Control Measure 18 (end of circular). Spraying trees with DDT will reduce the number of leafhoppers and check the spread of phloem necrosis, but mite infestations may follow.

Mites.-Several species of mites infest elms, but usually the damage they do is of little consequence. However, following the repeated use of DDT on elm foliage, infestations of the two-spotted spider mite, Tetranychus telarius (L.), fig. 43, may become dense enough to bronze the leaves and reduce the vitality of trees.

Control Measure 9 (end of circular).

\section{EUONYMUS}

Euonymus Scale, Unaspis exomymi (Comst.), fig. 26.-This most important and destructive pest of euonymus is common also on bittersweet and pachysandra. The great number of white coverings of the males on the under sides of the leaves of infested plants immediately attracts attention and serves to help identify the pest. The female lives under a gray or brown shell, shaped somewhat like the shell of an orster. In spring, the overwintering female lays orange-yellow eggs, which produce crawlers that leave the mother shell and find a place to settle and grow on the host plant. This scale produces at least two generations a year.

Control Measure 3 (end of circular) about July 1 when hatching of eggs is complete. The spray should be repeated early in September. 

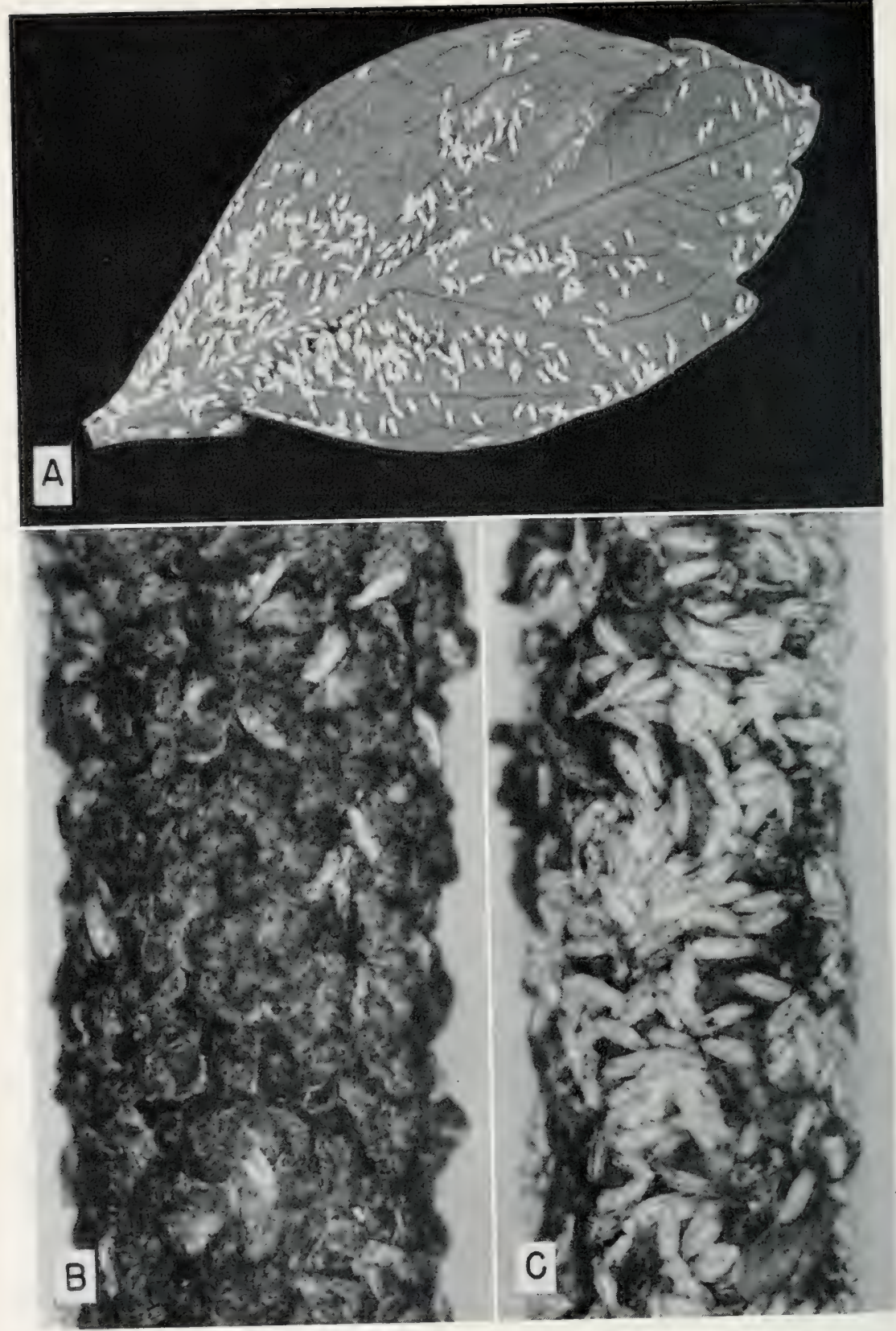

Fig. 26.-Euonymus scale: infestations on leaf, $A$, and twigs, $B$ and $C$, of euonymus. Nost of the scales shown are males, each of which has a white covering. The dark scales on twig $B$ are females. 


\section{HACKBERRY}

Hackberry Nipple Gall Psyllid, Pachypsylla celtidis-mamma (Flet.).-Conspicuous growths on the upper sides of hackberry leaves are signs of an infestation of this insect, sometimes called

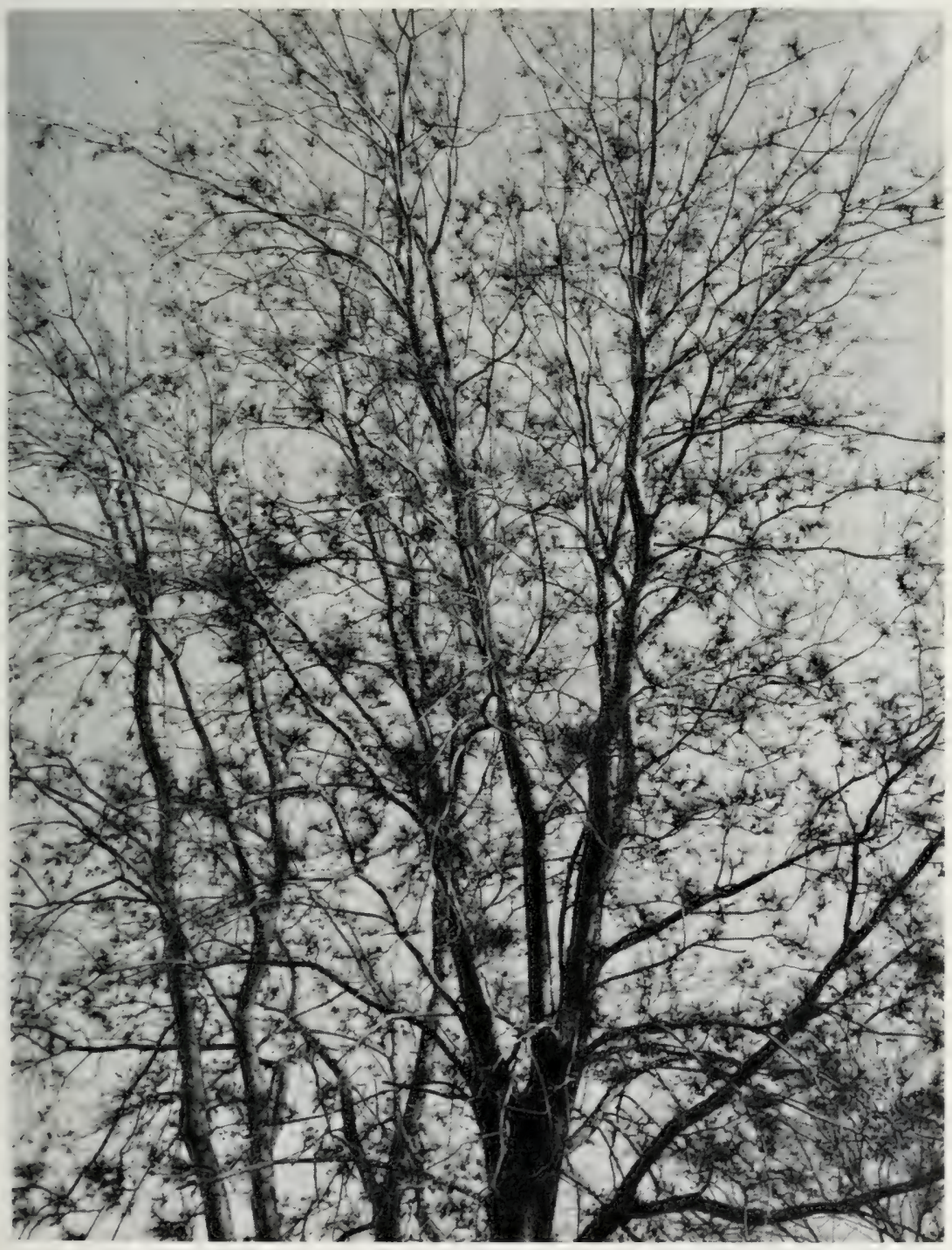

Fig. 27.-Witches'-brooms on a hackberry tree. The brooms are very conspicuous in winter, when no leaves are on the tree. 
at jumping plant louse. Formation of each gall is stimulated by a tiny insect that feeds and lives inside the gall. The small, yellowish-brown adults pass the winter in bark crevices of trees or in the debris under trees. About the time leaf buds unfold, the female deposits eggs on the under sides of leaves. When the eggs hatch, each young insect crawls to the upper side of a leaf, settles down, and begins to feed through a short beak. The leaf tissue grows around the insect in characteristic fashion to for $\mathrm{m}$ a gall. By September the insect completes its development and emerges as an adult through a slit it makes in the base of the gall. At that time of year, insects of this species may make nuisances of themselves by flying into houses.

Control Measure $\&$ (end of circular) applied to trees about the time the leaves begin to unfold.

Witches'-Broom, fig. 27.-Abnormal growth that results in bunches or tufts of small twigs on the limbs and branches of hackberry is commonly called witches'-broom. Apparently the brooms do little harm to an affected tree, but they detract from its appearance. A tiny mite, Aceria snetsingeri Keifer, and a fungus, Sphaerotheca phyloptophila Kell. \& Swingle, are associated with witches'-broom, but it is not known whether either or both stimulate the peculiar growth.

Control. No satisfactory measure for the control of witches'-broom on hackberry has been developed.

\section{HICKORY}

Yellow-Necked Caterpillar, fig. 10.--See under Crabs and Hawthorns. Control Measure 1 or 2 (end of circular).

Hickory Bark Beetle, Scolytus quadrispinosus Say.-Small emergence holes in the bark of the trunk and branches of a hickory tree are signs of an infestation by this species. The adults are dark brown beetles, each less than one-fourth inch long. After emerging from beneath the bark, each beetle feeds for a short time on young twigs, then bores through the bark of the same or a different tree, and constructs a gallery between the bark and the wood. Along the edges of the gallery, the female deposits eggs that give rise to white, legless grubs, which cause further and more extensive damage.

Control Heasure. This species is especially injurious to hickories growing in parks. Heavily infested trees should be 
cut down during the winter to destroy overwintering grubs. Healthy trees should be kept in a vigorous condition with applications of water and fertilizer.

Hickory Gall Phylloxera, Phylloxera caryaceaulis Fitch.Often overlooked until the affected twigs have died and the globular galls have been abandoned and have turned black, the greenish insects of this species may cause considerable or little injury to hickories, depending on the degree of infestation. After hatching from overwintering eggs, the young aphids stimulate the growth of galls on new twigs and prevent normal growth or kill the twigs beyond the galls. Each gall, which is at first green and may be one-half to three-fourths inch in diameter, is crowded on the inside with the greenish plant lice.

Control Measure 5 (end of circular) in winter or Control Measure 8 about the time buds unfold.

Hickory Horned Devil or Regal Moth, Citheronia regalis (F.).- The larval form of this insect is an occasional leaf eater of hickory as well as several other trees. It looks enough like the devil to be frightening. Approximately 5 inches long, this largest of our native caterpillars has a green body, a red head, and curving red horns just back of the head. In contrast, the adult insects are beautiful olive-green moths with a wing expanse of 4 to 6 inches.

Control Measure. Although a ravenous feeder, the hickory horned devil does not occur in sufficient numbers to justify spraying. Caterpillars on small trees can be collected and destroyed by hand.

\section{JUNIPER}

Juniper Scale, Diaspis curueli Targ., fig. 28.-This pest is common on various kinds of junipers, especially on plants used for landscaping. The covering of the female scale is nearly circular and is dirty white in color. The covering of the male scale is white; it has a median ridge and is narrower and smaller than that of the female. Juniper scale may develop into a dense population on twigs and branches of junipers, causing them, or even entire plants, to die. In May, the overwintering female deposits eggs, which hatch in June.

Control Measure 3 (end of circular) about July 1, after eggs hatch. 
Juniper Webworm, Dichomeris marginella (F.), fig. 29.The larva of this species is a light brown caterpillar only about one-half inch long. Several caterpillars web together and feed on juniper foliage, causing it to turn brown and die. Development of the caterpillars is completed in early summer. Pupation occurs

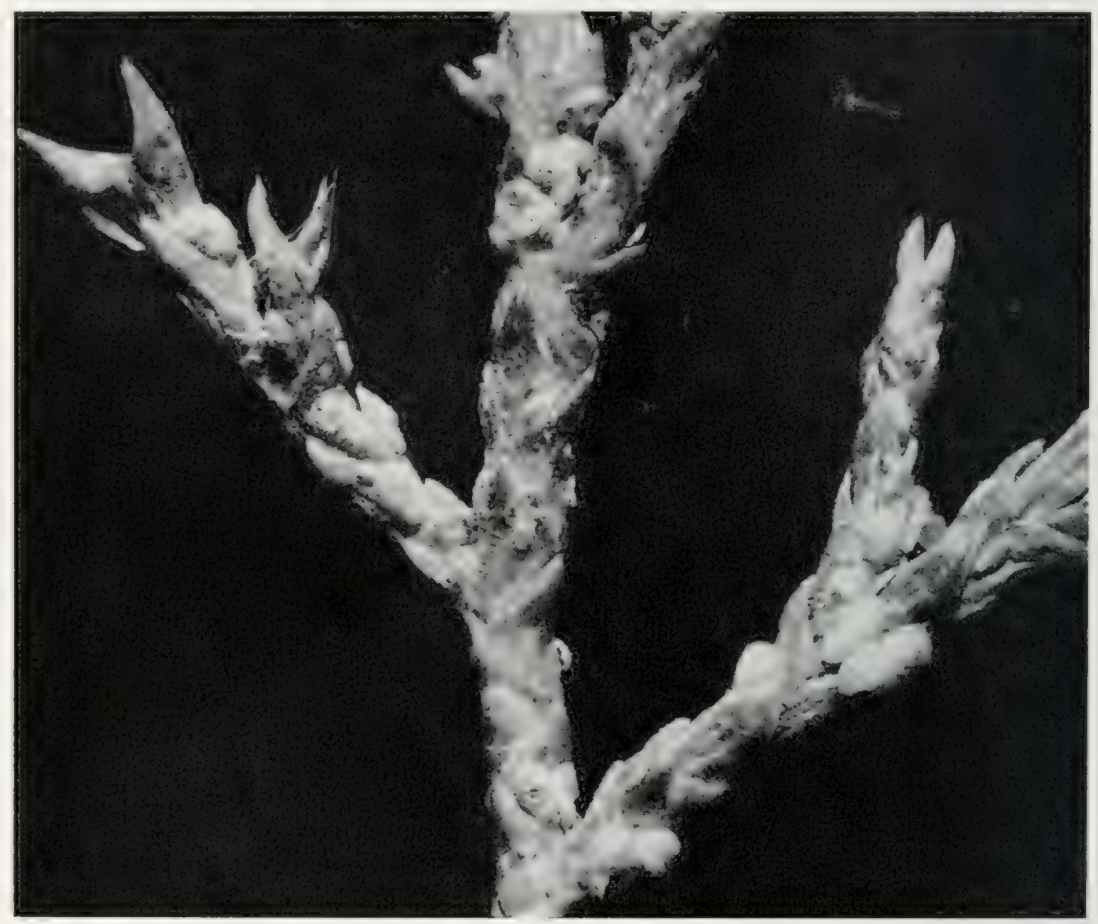

Fig. 28.-Juniper scale: an infestation on juniper. Dark red, sapsucking scale insects are under the gray or white shells on the surfaces of $t$ wigs.

in the webbing and debris; from each pupa a moth emerges. The female deposits eggs on foliage to produce another brood of caterpillar's that pass through the winter. The caterpillars become active again in the spring.

Contmol Meusure 1 or ? (end of circular) as soon as the caterpillars are discovered. Spray should be applied forcefully.

Juniper Bark Beetle, Phlocosinus dentatus Say.-Several kinds of junipers are damaged by the adults of this species, dark brown, tubular beetles, each about one-sixteenth inch long. Beginning in early spring, the beetles feed in the crotches of small 
branches, weakening many of them so that they bend down, break, and die.

Control Measure 1.3 (end of circular) at monthly intervals during the spring and summer, beginning about April 15. If mites develop, Control Measure 9 also should be used.

Spruce Spider Mite.-See under Spruce. Control Measure 9) (end of circular).

Bagworm, fig. 2.- See under Arboritae. Control Measure 1,3 , or 11 (end of circular) in June, while worms are small.

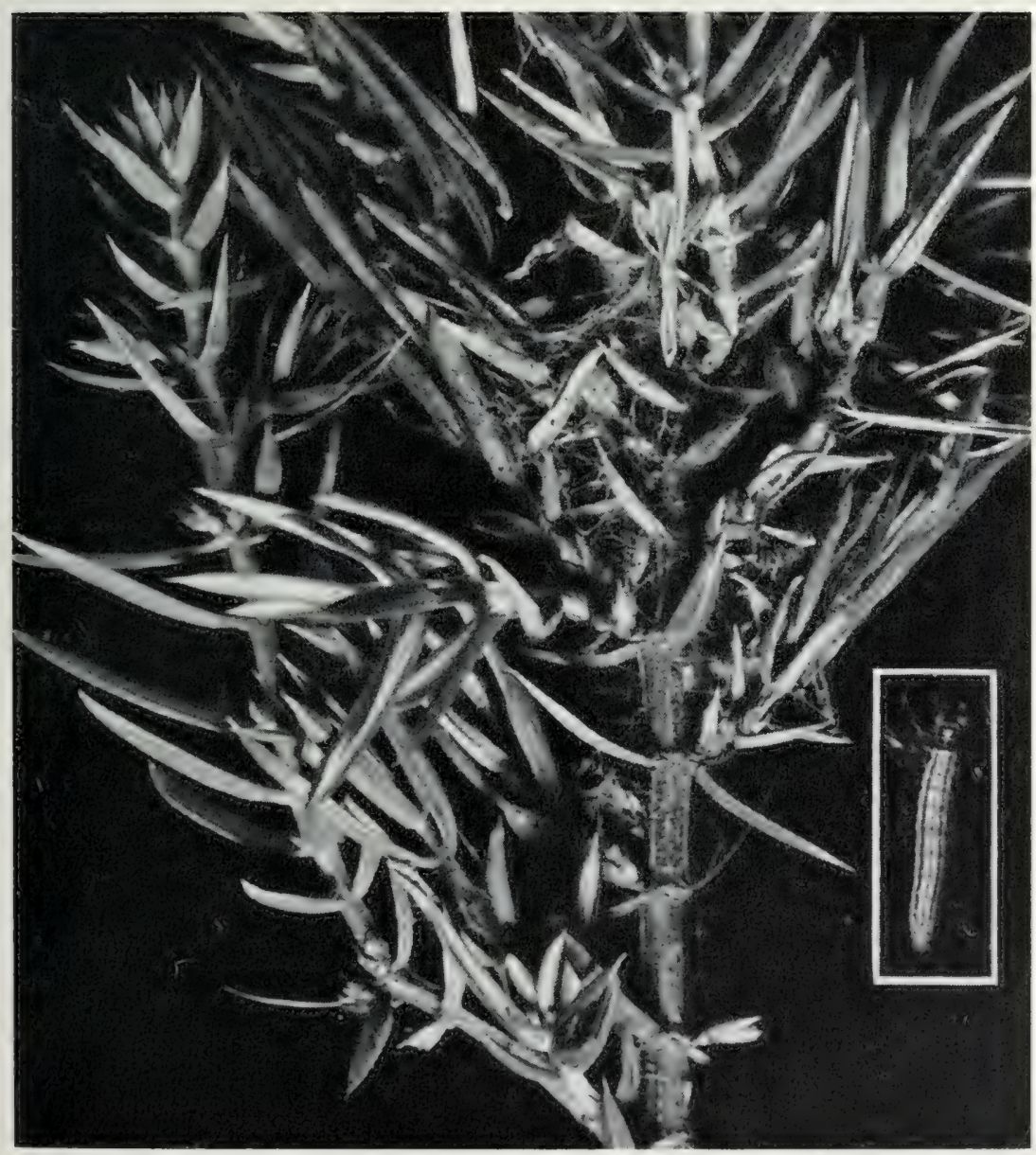

Fig. 29.-Juniper webworm: larva (inset) and web on damaged branch. A colony of the small, brown caterpillars of this insect usually kills an infested branch. 


\section{LILAC}

Lilac Borer, Podosesia syringae syringae (Harr.), fig. 30.The larva of this insect is a major pest of lilac. The adults are moths that have transparent rear wings. Holes made in the bark of lilac by the grubs are likely to be numerous and are characterized by protruding sawdust, oozing sap, and, in the spring, by brown pupal cases at the entrances of emergence holes. Eggs deposited by the female in early summer on rough bark give rise to the white grubs that bore through the bark into the wood beneath, where they feed and grow until winter brings their activities to a halt.

Control Measure 4 (end of circular).

Oystershell Scale, fig. 5.-This is a major pest of lilac. See under Ash. Control Measure 5 (end of (ircular) in late winter or Control Measure 3 in early summer.

\section{LINDEN}

Elm Spanworm, Ennomos subsignurius (Hbn.).-The adult form of this species is sometimes called the snow-white linden moth. Both male and female are pure white. The larva or caterpillar is a gray and brown looper with irregular yellow marks. Outbreaks of this insect occur at intervals of 10 to 20 years. The female moth deposits eggs in the summer on tree branches. The eggs do not hatch until the next spring. When outbreaks occur, the caterpillars are present in such numbers that they defoliate linden and several other kinds of trees.

Control Measure 1 or 2 (end of circular).

\section{LOCUST}

Locust Borer, Megacyllene robiniae (Forst.), fig. 31.-Black locust is particularly susceptible to the larva of this insect. The larva is white, cylindrical, and up to 1 inch long. At first it mines the bark and sapwood of the locust, but later it bores into the heart of the tree, often causing so much damage that the trunk breaks. Growth, pupation, and transformation of the insect take place in the wood. The adults are beetles that emerge in autumn and feed on the pollen of goldenrod. Each is about three-fourths inch long, black, and has zig-zag yellow lines across the back. 


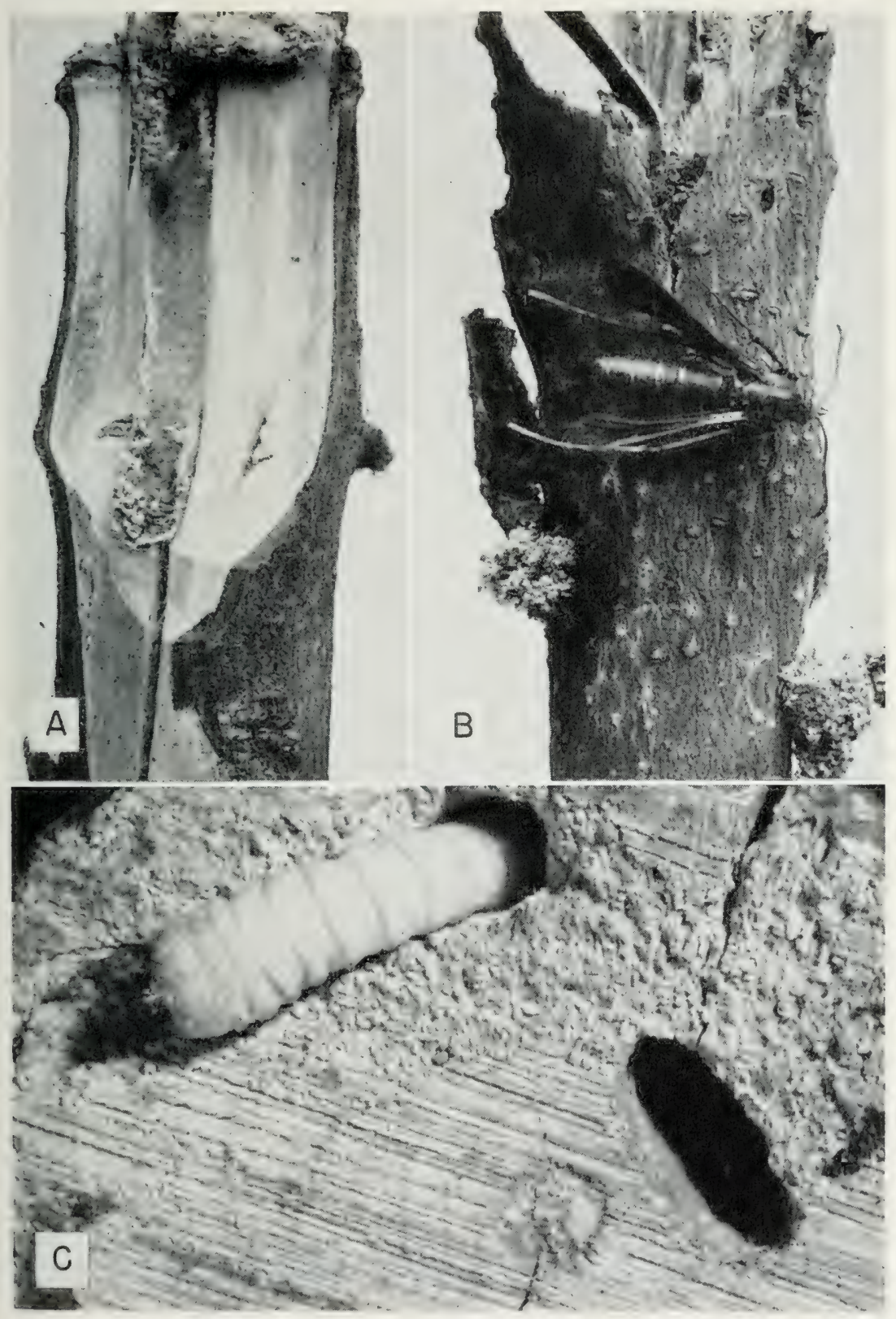

Fig. 30.-Lilac borer: $A$, damage to lilac branch; $B$, adult, a clearwinged moth, on twig with frass at exit holes; $C$, larva in lilac branch (cross section). (Photographs $A$ and $B$ from Connecticut Agricultural Experiment Station.) 

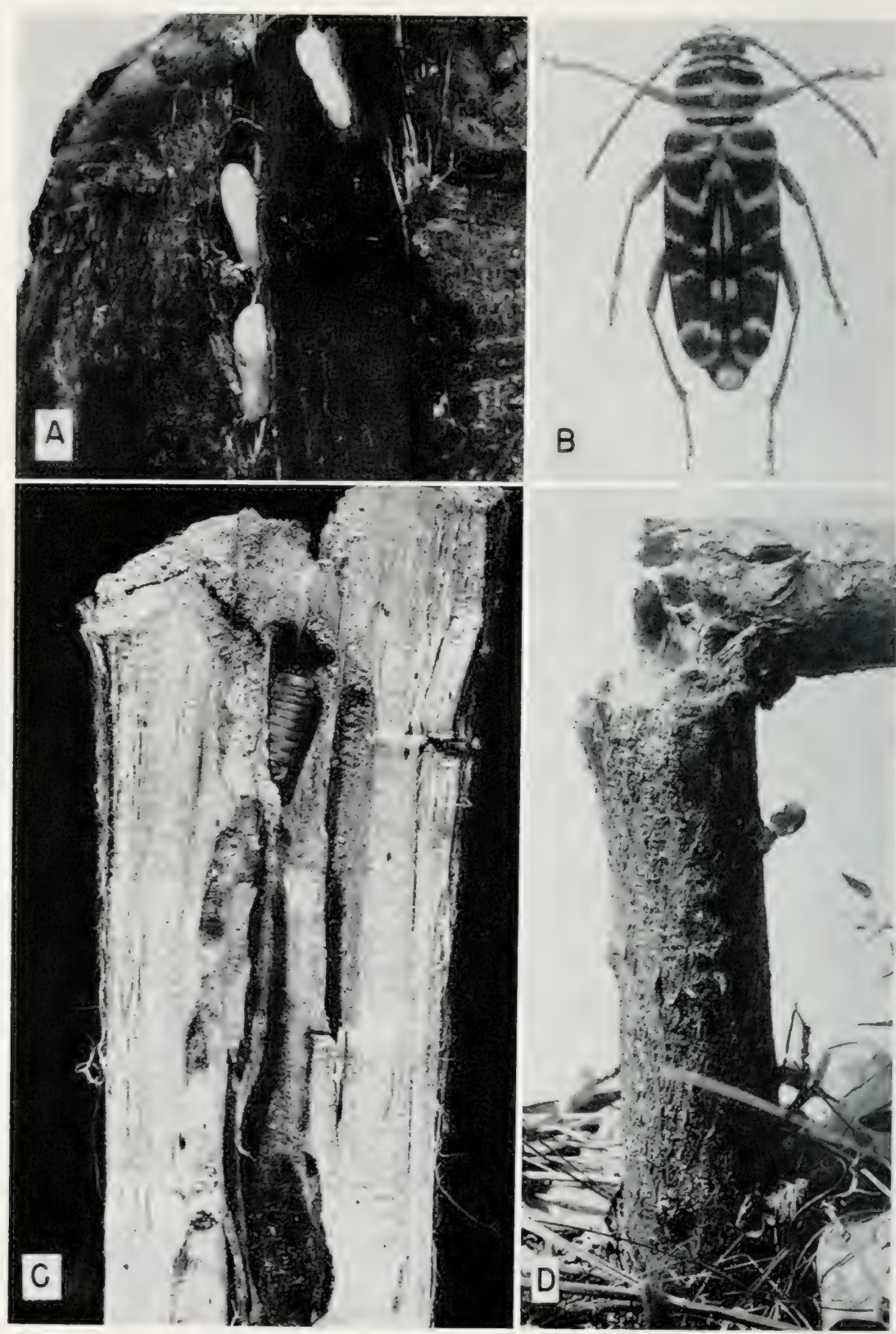

Fig. 31.-Locust borer: $A$, eggs in crevices of limb; $B$, adult, mostly black but with yellow markings; $C$, larva in its burrow in trunk of young locust; $D$, young locust tree broken over by wind after damage by locust borer. (Photographs from Ohio Agricultural Experiment Station.) 
The female deposits eggs in the cracks and crevices of locust bark.

Control Measure \& (end of circular) for protection of young trees. Honey locust, which is not readily attacked, should be used for shade in place of black locust.

Bagworm, fig. 2.-This pest occur's on both black locust and honey locust. See under Arborvitae. Control Measure 1, 3, or 11 (end of circular) in June, while worms are small.

Locust Mite, Eotetranychus multidigituli (Ewing). - This mite, somewhat similar to other species of mites found on trees and shrubs, seems to be peculiar to honey locust. Just large enough to be visible to the naked eye, the mite varies in color from pale yellow to green; it has irregular dark areas near the edge of the body. The female deposits colorless spheroid eggs along the midrib of the under side of a leaflet. The base of the leaflet on the under side is the preferred feeding area. At first, heavily infested foliage appears stippled from above, but later it becomes blanched, and leaflets drop prematurely.

Control Measure 9 (end of circular) when mites occur.

Mimosa Webworm, Homadaula albizziae Clarke.-This pest, relatively new in Illinois, has been observed in the Washington, D. C., area on mimosa since 1940 and on honey locust since 1943. Damage to the foliage of these trees may be extensive.

The adults, mouse-gray moths, each with a wing expanse of only about one-half inch, emerge from overwintering pupae early in June. The female deposits eggs on the leaves of honey locust or mimosa. The small, pale gray to brown larvae web the leaves together to form a sort of nest, in which they skeletonize the leaflets. Badly damaged leaflets become dry and brown. In Iliinois, such symptoms of webworm attack may appear by the latter part of July. When grown, each larva drops to the ground on a silken thread to pupate under ground cover. Second brood larvae produce conspicuous webbing in August. In the Washington, D. C., area, the mimosa webworm produces a partial third generation each year.

Control Measure 1 or 2 (end of circular).

\section{MAPLE}

Cottony Naple Scale, Pulvinaria innumerabilis (Rathv.), fig. 32.-A common, conspicuous, and injurious pest of soft ma- 
ple, this species is found on several kinds of maples and a variety of other trees and shrubs. The infestations may be heavy enough to kill twigs, branches, limbs, arid, occasionally, entire trees. The scale insects secrete great quantities of honeydew that drips

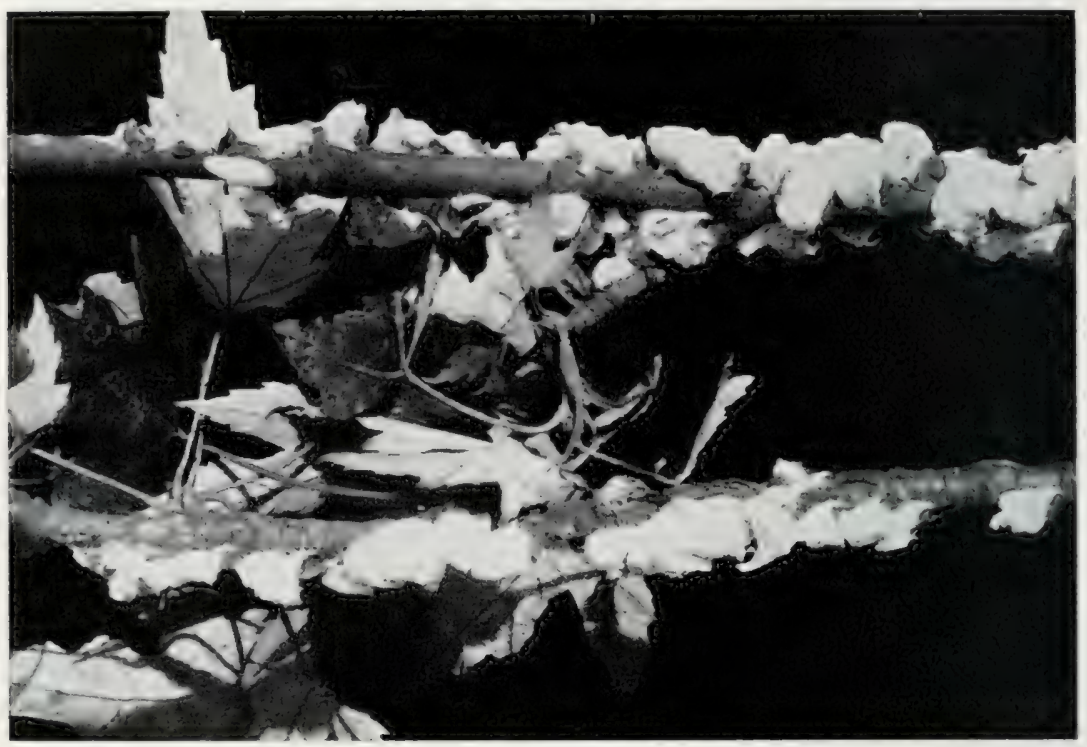

Fig. 32.-Cottony maple scale: infestation on soft maple. An infestation of this insect can be identified easily by the masses of white wax, each of which contains hundreds of eggs.

on branches and foliage of infested trees, and on sidewalks and automobiles below. A sooty mold that sometimes grows in the honeydew causes branches and foliage to appear black.

The partly grown, brown, oval, female scale overwinters on a twig or branch. She grows rapidly in the spring and lays hundreds of eggs in a mass of cottony threads. Heavily infested branches appear as if decorated with popcorn. When the eggs hatch in June or July, young scales migrate to the leaves, where they settle and suck food from the leaf tissue. The males and females become mature in August; after mating, each female crawls back to a twig for the winter.

Control Heasure 5 (end of circular) late in the winter or Control Hecsure 3 in summer. Fortunately, cottony maple scale has many natural enemies which help control it. However, at times sprays may be needed. 
Maple Bladder-Gall Mite, Tasutes quadripedes (Shimer), fig. 33.-Unsightly green and reddish growths (galls) on the upper sides of the leaves of soft maple are signs of an infestation of the extremely small mites of this species. The mites overwinter on the bark of trees and in spring migrate to young leaves, where they stimulate the formation of galls, in each of which many mites live and feed. It is doubtful if galls associated with this species cause enough damage to large, vigorous trees to justify

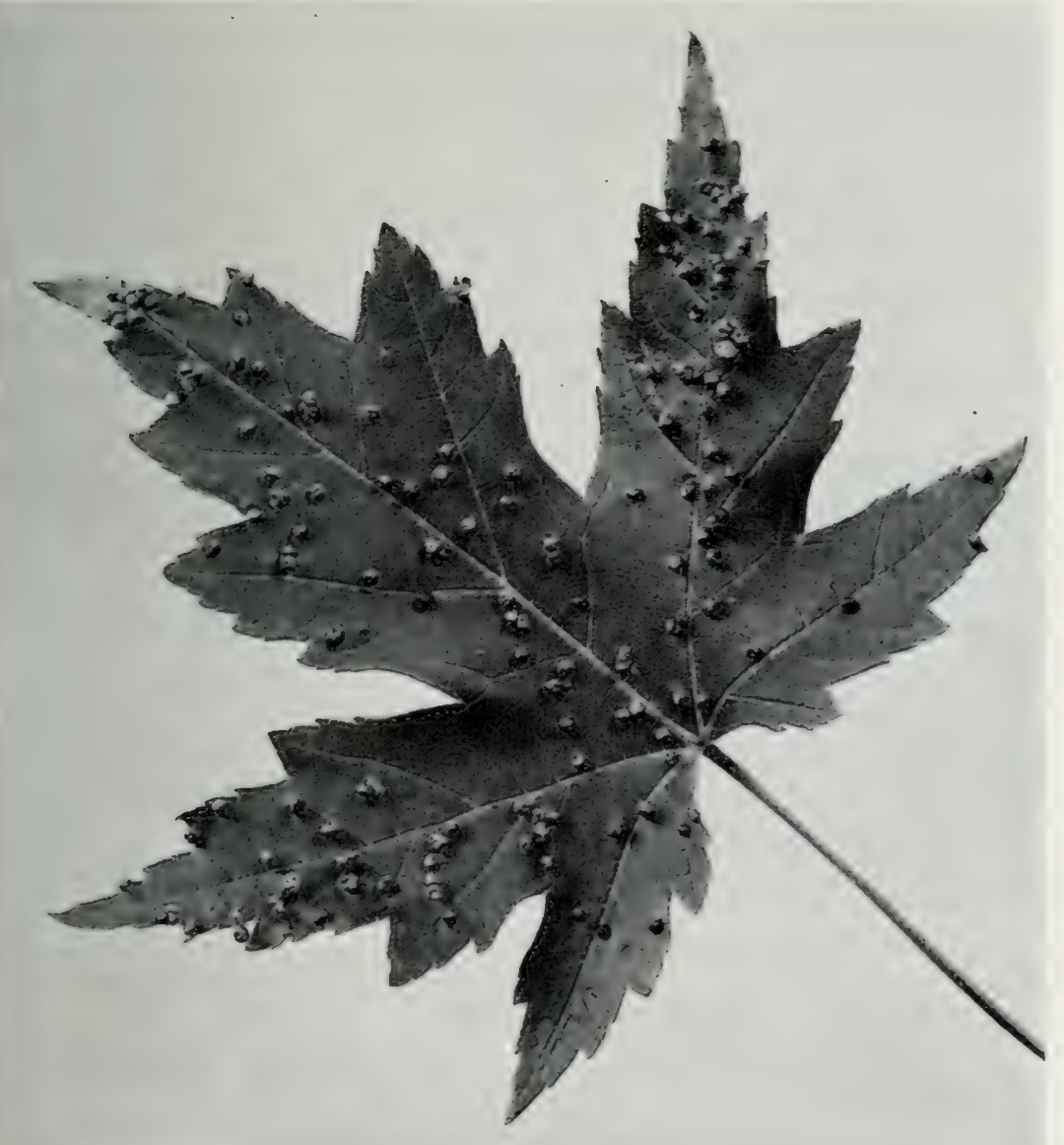

Fig. 33. - Maple bladder galls on the upper side of a soft maple leaf. Growth of each gall is stimulated by extremely small mites, which live in the gall. This mite apparently causes little damage, except possibly to small trees. (Photograph from Michigan State University.) 
spraying. Small trees, struggling for a start, may be benefited by spraying.

Contiol Measure of (end of (ircular) after buds are swollen but before new leaves appear in spring. Sprays applied after galls develop are useless.

Green-Striped Mapleworm, Anisota rubicunda (F.).-An occasional pest of maple, the caterpillar of this species consumes entire leaves, and an infestation may defoliate a tree within a short time. The full-grown caterpillar is about 2 inches long. It is yellowish-green in color, has green stripes running lengthwise on its back, spines on its sides, and two horns on its thorax. The adults or moths of this species emerge in early spring from pupae in the soil; the female lays eggs on leaves of maples. The insect may produce two generations in a year.

Control Meusure 1 or 2 (end of circular) as soon as an infestation is discovered.

Flatheaded Apple Tree Borer, Chrysobothris femorata (Oliv.), fig. 34. - The larva of this common and widely distributed insect attacks a great variety of shade trees and fruit trees.
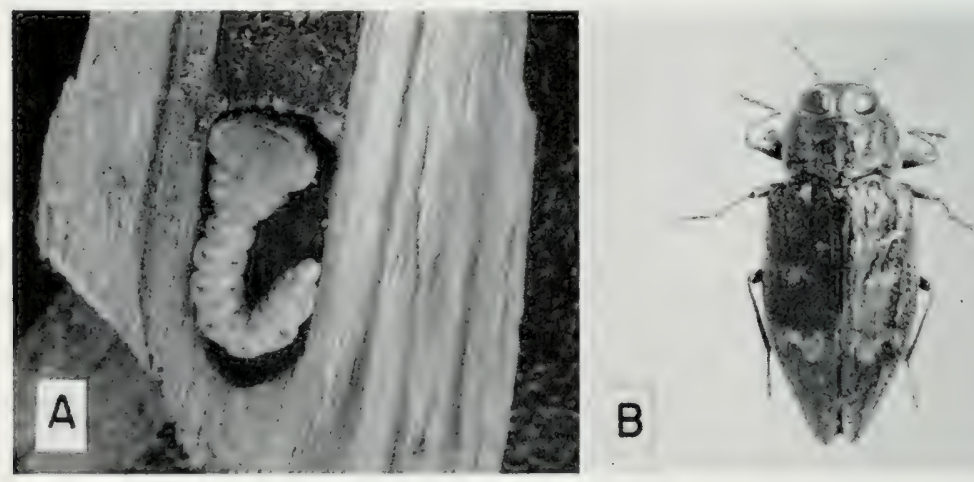

Fig. 34. - Flatheaded apple tree borer: $A$, larva; $B$, adult, a gray or brown metallic-colored beetle about one-half inch long. (Photographs from United States Department of Agriculture.)

Almost any tree that is weakened by transplanting or dry weather or is wounded or damaged by sunscald may be invaded by this destructive borer. The adults are flat, metallic-colored beetles, each about one-half inch long. The female lays eggs in cracks and crevices in the bark of a tree; the young borers that emerge from these eggs have little trouble in boring through and tun- 
neling under the bark. Often, trees are girdled by the white, legless, slender grubs with big flat heads. Feeding mainly in the sapwood at first, each grub mines (leeper as it becomes larger and when grown it makes enough room at the end of a tunnel to spend the winter. Pupation and transformation take place in the early spring. At this time, an adult emerges through the tunnel made by a borer. The life cycle of the flatheaded apple tree borer is completed in a year.

Control Measure 4 (end of circular).

Aphids.-Two species of aphids are pests of maples. They suck sap from the under sides of maple leaves and secrete enough honeydew, at times, to wet the sidewalks and streets under the trees. The Norway-maple aphid, Periphyllus lyropictus (Kess.), is a greenish insect that feeds along the veins on the under sides of the leaves of Norway maple and hard maple. The painted maple aphid, Drepanaphis acerifoliae (Thos.), is gray or black in the winged form and yellow in the wingless form. It is more common on soft maple than on other maples.

Control Measure 3 (end of circular) if damage is apparent and if the nuisance caused by the aphids is insufferable. Aphids usually do not cause enough damage to large trees to justify the expense of spraying.

Pigeon Tremex, Tremex columba (L.).-Associated with diseased and dying maples and many other kinds of trees, the pigeon tremex may be erroneously blamed as a serious tree pest. Each almost 2 inches long and with a reddish head and thorax, the adults are wasplike sawflies that bore holes in the trunk of a tree; there the female deposits eggs which hatch into grubs that live in the infested tree until development and transformation are completed.

Control. A slender parasitic wasp belonging to the great family of parasites, the Ichneumonidae, probably does more to control the pigeon tremex than could be done with all sorts of insecticides. With her ovipositor, a long threadlike appendage at the end of her abdomen, the female of this wasp, with uncanny precision, drills into a tremex tunnel and deposits an egg which produces a larva that attaches itself to the tremex grub and kills it.

No insecticide treatment is recommended for the pigem tremex. Trees infested by the tremex probably should be cut down and removed because they are dying from other causes. 


\section{OAK}

Borers.-Like other trees when weakened by transplanting shock, dry weather, or poor environment, oaks may be attacked by several species of borer's. The flatheaded apple tree borer (see under Maple) and the carpenterworm (see under Poplar) are common pests of oaks.

Control Measure \& (end of circular).

Periodical Cicada, Magicicada septendecim (L.), fig. 35.The female of the periodical cicada, which seems to prefer the terminal twigs of oaks for laying eggs, causes damage by tearing the bark and wood where she thrusts eggs into a twig. The damage resulting from many egg deposits in a twig causes it to die, and possibly to break off. Tiny nymphs hatch from the eggs, drop to the ground, burrow into the soil, and subsist for a 13- or 17-year period on the plant juices they can obtain from roots. The nymphs emerge from the ground in early summer, attach themselves to nearby objects, and molt to become adults. Both male and female are black and robust; they have reddish eyes, legs, and wing veins. With strident song, the males announce the presence of cicadas in great swarms at intervals of 13 or 17 years.

Control Measure 19 (end of circular).

May Beetles, Phyllophaya spp.-The adults of many species of Phyllophaga (May beetles or June bugs) feed on the foliage of oaks and other trees, sometimes in such numbers that they defoliate small trees. These adults, which feed at night, are attracted to lights. Most of the beetles are solid brown in color and are one-half to three-fourths inch long. Eggs deposited by the female in the soil produce larvae, white grubs, that feed on the roots of grasses and other plants. Most May beetles have a 3-year life cycle.

Control Measure 1 or ? (end of circular) when beetles are feeding.

Twig Pruner, Hypermallus villosus (F.).-Although not a major pest, the larva of this species when present in considerable numbers may litter a yard in late summer with twigs from oaks, elms, hickories, maples, and other trees. A clever animal, the larva tunnels around a twig under the bark, cutting into the twig to such an extent that it is easily broken off in the wind. Having burrowed farther toward the tip of the twig, the pruner falls with 

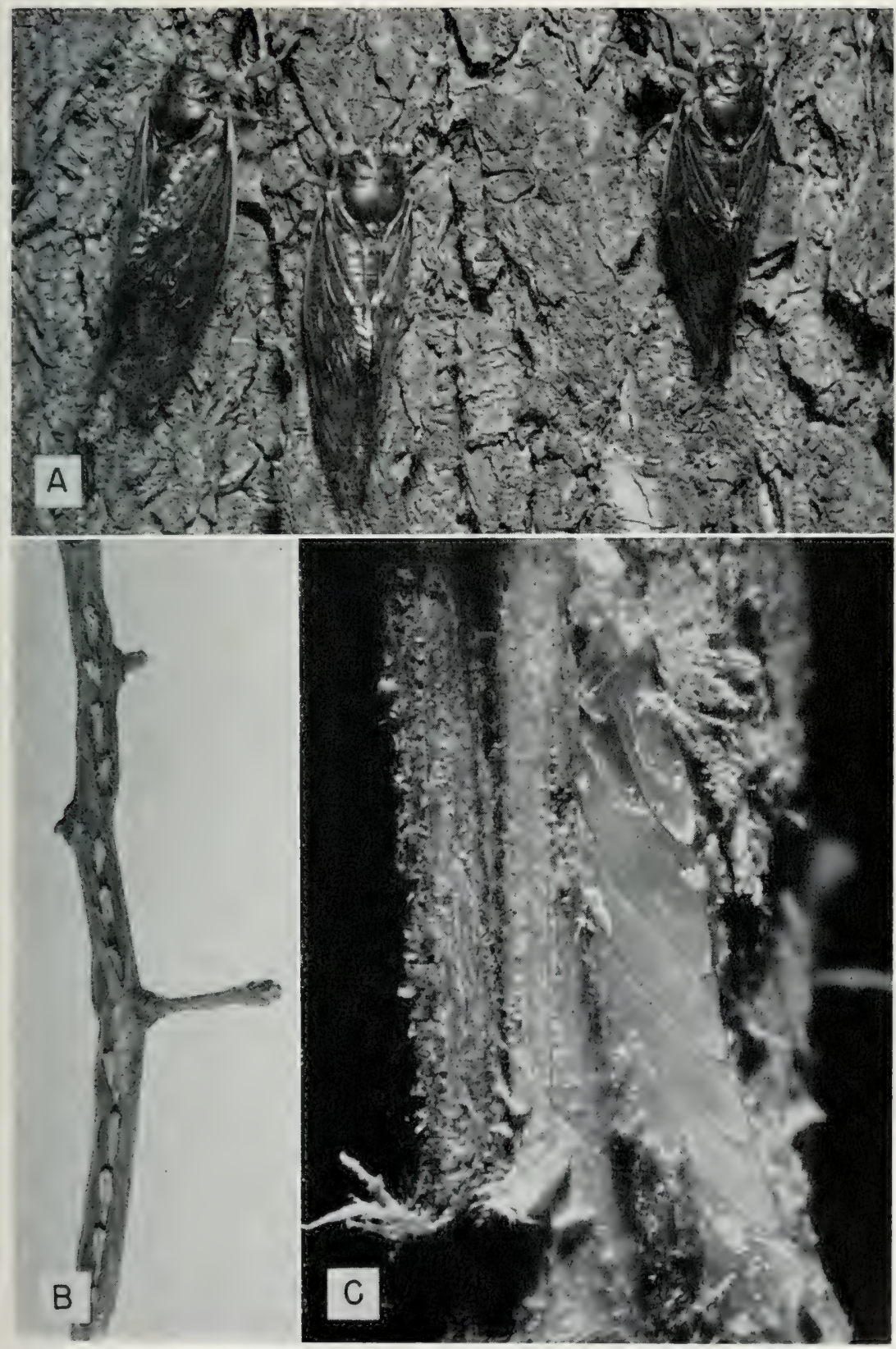

Fig. 35.-Periodical cicada: $A$, adults on trunk of tree; $B$, punctures made in twig by adult female in laying eggs; $C$, eggs in tissue of twig. Damage to oaks is very conspicuous following an outbreak of the cicada. 
the twig to the ground, where transformation occurs. The adult is a rather slender, brown beetle, about three-fourths inch long, that emerges from the pupa. The female lays eggs in twigs in early summer.

Control Measure 20 (end of circular).

Oak Kermes, Kermes pubescens Bogue, fig. 36.-Of most importance on bur oak, but sometimes found on chinquapin, white oaks, and red oaks, the oak kermes is closely related to the scale

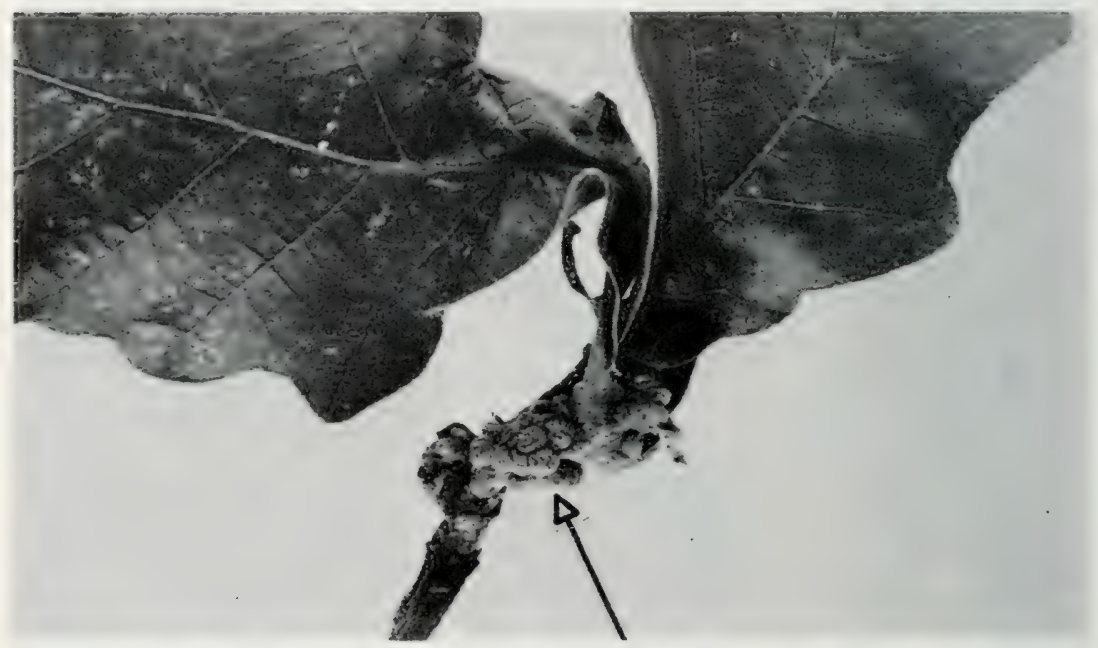

Fig. 36.-Oak kermes: an infestation of this almost spherical scalelike insect at the base of a new shoot.

insects. After wintering on the bark of twigs and branches, the oak kermes migrates to a growing shoot. Where numerous individuals cluster around shoots and on the under sides of the leaves, they distort and kill the new growth. The full-grown female kermes is about one-eighth inch in diameter, almost spherical, light brown in color, and covered with very fine fuzz. The male produces a tiny white cocoon, in which it develops. In the spring, each female lays sereral hundred light brown eggs under her shell. In June, the reddish-brown crawlers that emerge from the eggs leave the mother shell to find a suitable place for feeding.

Control Measure 5 (end of circular), before the buds swell, to kill the adults; or Control Meusure 3, about July 1, to kill the crawlers. 
Leaf Miners, fig. 37.-Leaf miners, larvae of tiny moths, fiies, sawflies, and small beetles, feed between the upper and lower surfaces of the leaves of oaks and many other shade trees, where they produce serpentine mines and blotches. Usually the female places her eggs on leaf surfaces, and each young larva, soon after it is hatched, bores into the leaf and proceeds to tunnel in various directions. If a mined leaf is placed in front of a bright light before the mine has been abandoned, the small larva that did the damage can be seen between the two leaf surfaces.

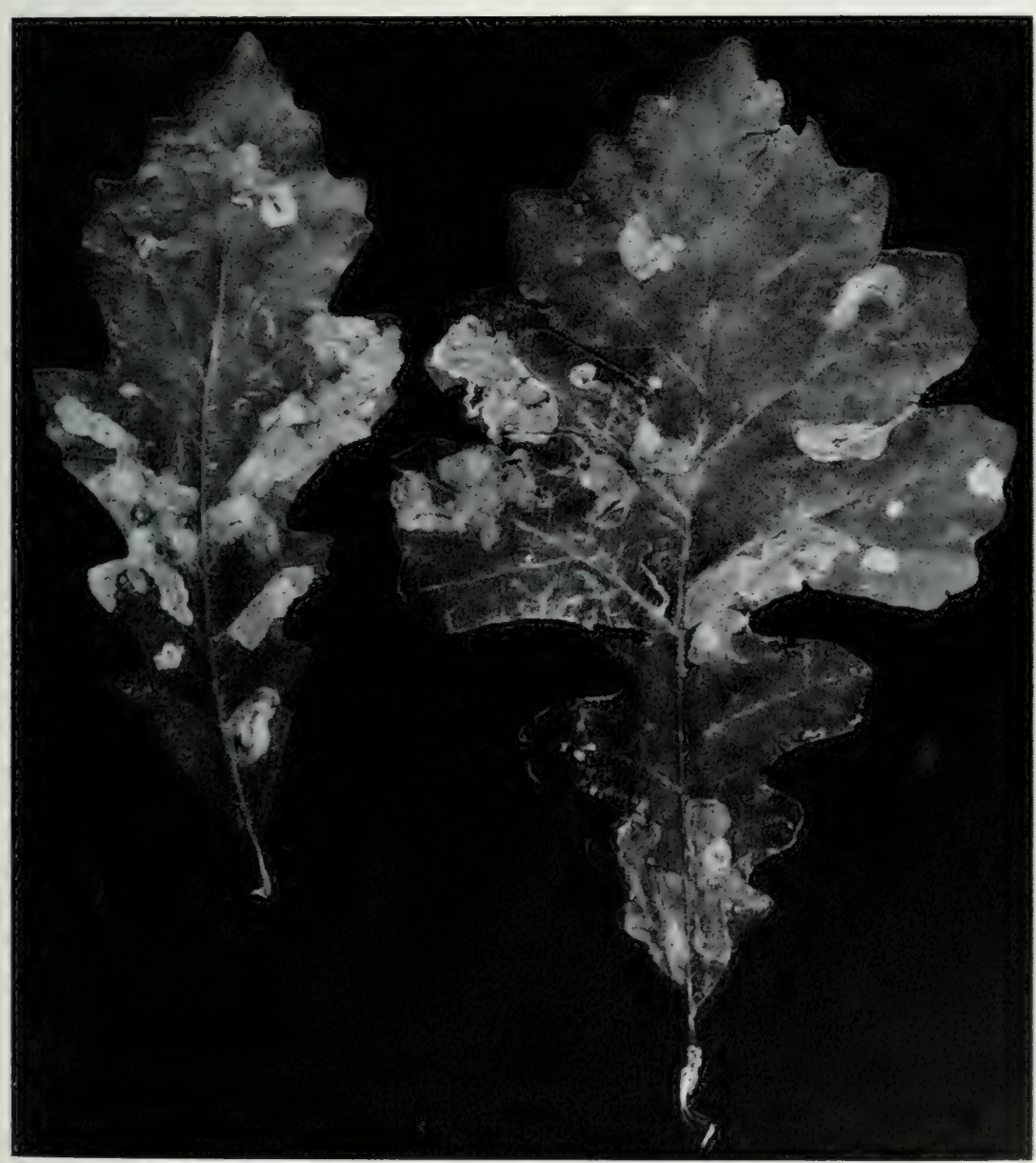

Fig. 37.-Leaf miners: damage to oak leaves. Very small larvae of several species of insects "mine" the leaves of oaks and other trees and destroy the tissue between the upper and lower leaf surfaces. 


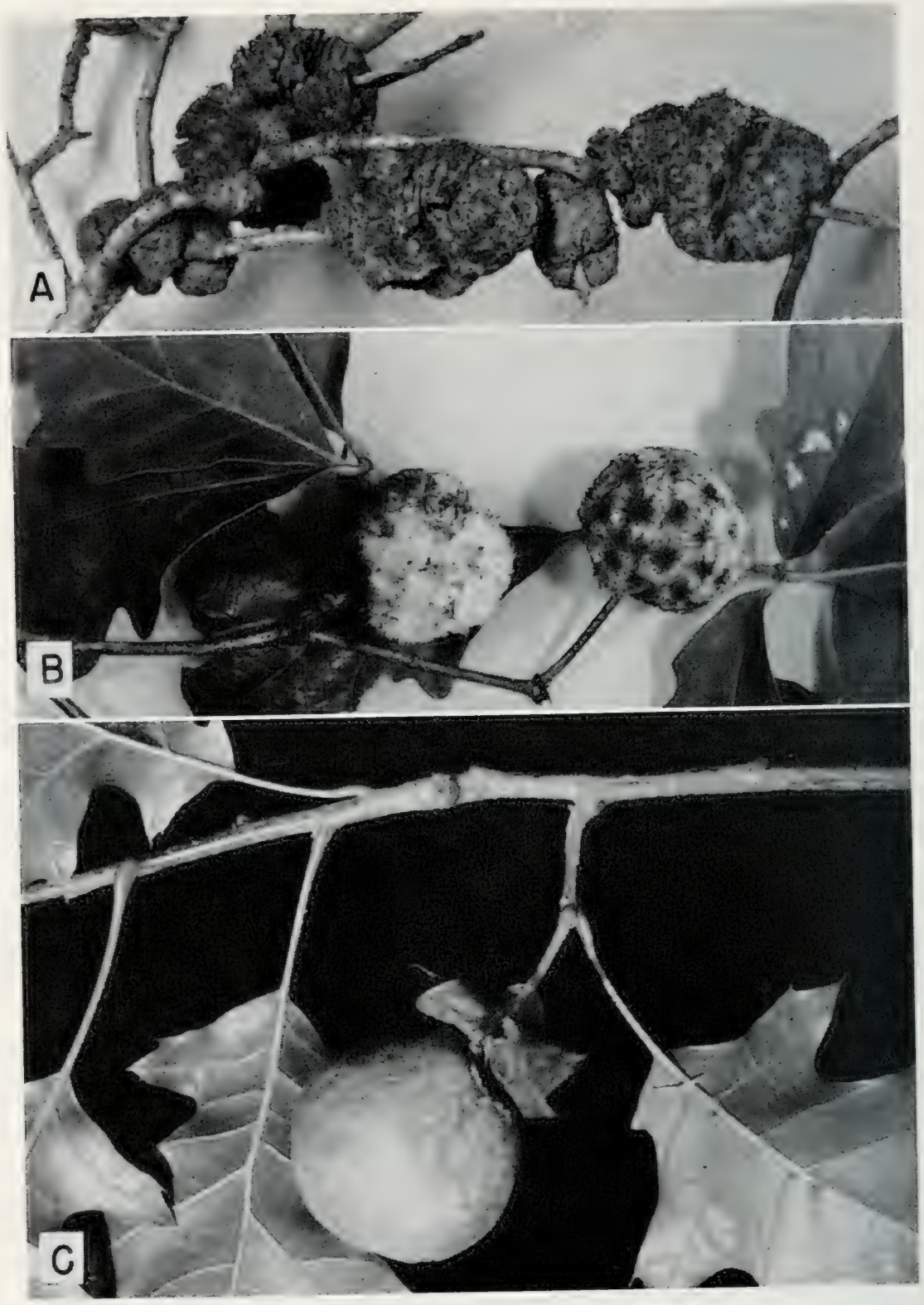

Fig. 38. Oak galls of three types stimulated by small wasps belonging to the family Cynipidae: $A$, gouty oak gall; $B$, wool sower gall; $C$, oak apple gall. The abnormal growth of plant tissue is stimulated in some mysterious fashion by these insects in the early part of the growing season. Each gall houses a colony of the wasps until development is completed, when the gall is abandoned. 
Control. In some species of leaf miners, the larvae drop to the ground with the leaves in the fall; these larvae may be destroyed if the leaves are burned. Until late years no insecticide for the control of leaf miners has been available. Recent work shows that Control Measure 1 't or 1.5 (end of circular) is effective against some species.

Gall-Producing Insects, fig. 38.-Galls appear on oak twigs in a variety of sizes and shapes that include irregular, bumpy, warty growths and smooth, attractive, spherical formations. These galls are not manifestations of a systemic disease and are no cause for alarm. One of the unattractive kinds, the gouty oak gall, fig. $38 \mathrm{~A}$, most often found on red oak, is produced by a small wasp belonging to the family Cynipidae. Individual cells, each inhabited by a larva of the wasp, make up the inside of the gall.

A woolly ball an inch or more in diameter, at first white but brown when older, is known as the wool sower gall, fig. $38 B$. Also produced by Cynipidae, this gall is not numerous enough to cause severe damage. The oak apple, fig. $38 \mathrm{C}$, is another spherical gall, green or brown in color, an inch or more in diameter, which sometimes occurs in clusters. The spongy mass inside each gall has a cell for the cynipid larva in the center.

Control. Damage to oaks by galls is rarely serious enough to justify spraying. Since galls provide protection for the insects inside, sprays applied after the galls develop are ineffective.

\section{PINE}

Sawflies, Neodiprion spp., fig. 39.-The larvae of sawflies are often seen as colonies of caterpillars feeding on pine needles. They are especially injurious to young pines, which may be killed by one defoliation. Each larva, about an inch long when grown, has a red, brown, or black head, and many larvae have rows of spots running lengthwise of their bodies. The insect overwinter's in a brown pupal case in the debris under a tree. Each less than half an inch long, the seldom-seen, beelike adults emerge in the spring. The female deposits eggs in slits she makes in pine needles. Although hard to see when first hatched, because of their small size, the sawfly larvae soon attract attention by the disappearance of needles required to meet their appetites. Sawflies may produce two generations a year.

Control Measure 2 (end of circular). 


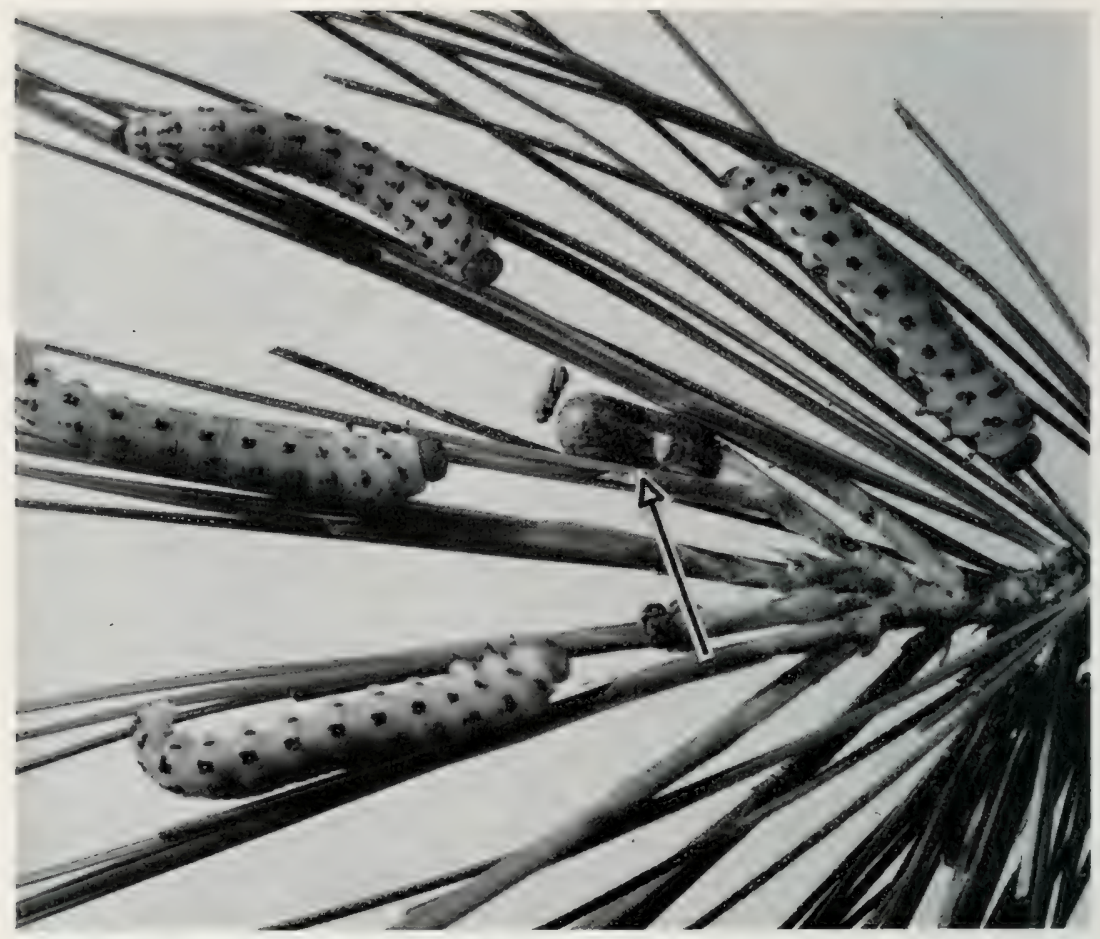

Fig. 39.-Red-headed pine sawfly: four larvae and a pupal case (arrow) on pine. Rows of black dots are conspicuous on the pale yellow larvae, which consume the needles of young pines and may cause serious damage to the trees. (Photograph from Pennsylvania State University.)

White-Pine Weevil, Pissodes strobi (Peck).-This pest prefers white pine, but it feeds upon Scotch and jack pines, also. Damage by the weevil is readily recognized by dead and dying terminal leaders of infested trees. The overwintering adults, each only about one-fourth inch long, feed on terminal twigs in the spring. At this time of year, the female deposits eggs on the terminal twigs. The larvae feed under the bark in the same general region, causing enough damage to kill the twigs.

Control Measure 2 (end of circular) about April 15.

Pine Neadle Scale, Phenacaspis pinifoliae (Fitch), fig. 40.Scales of this species appear as white specks along the needles of its favorite hosts, Austrian and Mugho pines, as well as other kinds of pines and some spruces. The purple insect under each shell sucks out sap and chlorophyll, reduces the vitality of the needles, and causes shedding of needles. Reddish eggs, which 


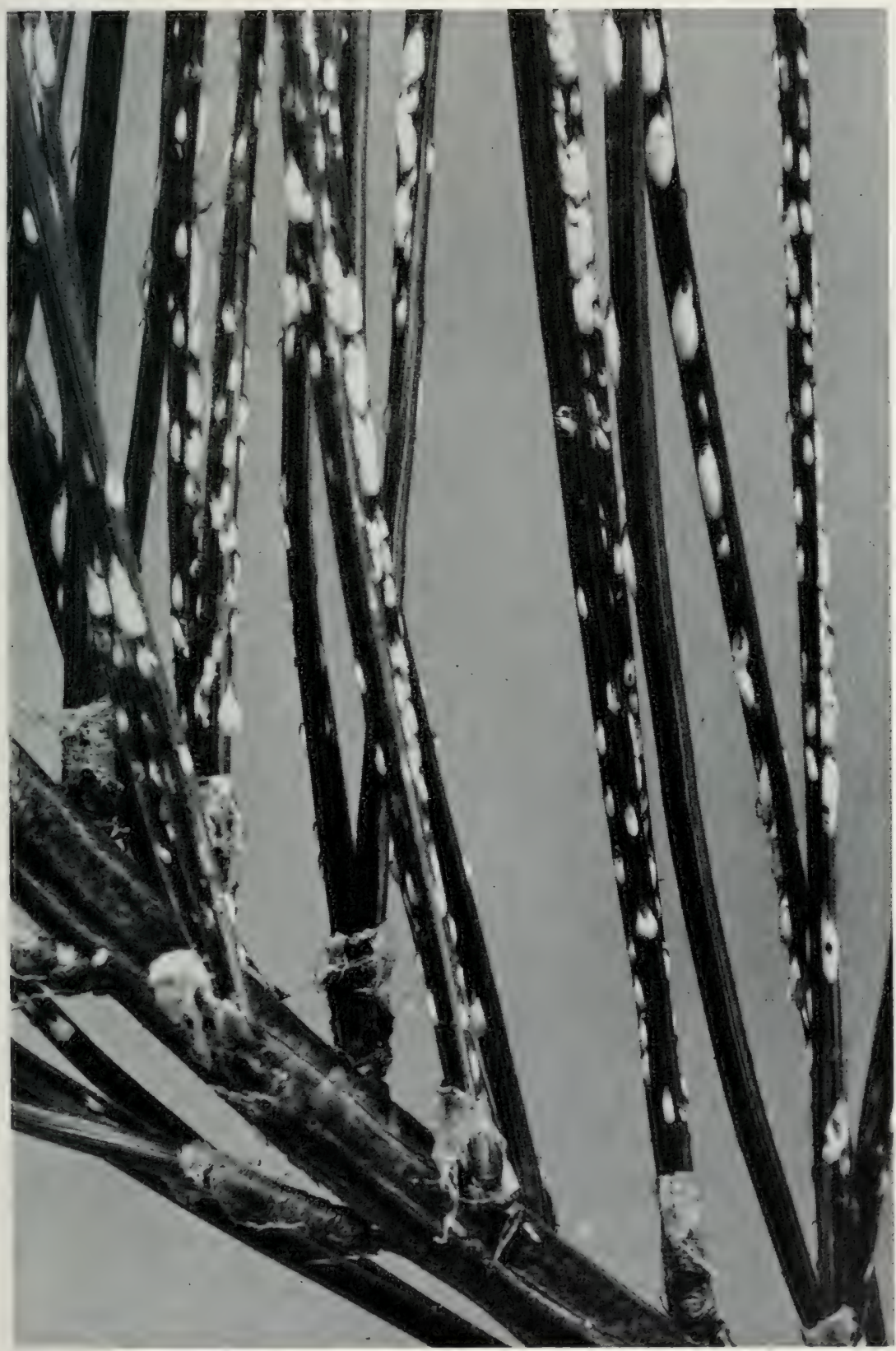

Fig. 10.-Pine needle scale: infestation on pine. Scales appear as white specks along the needles. (Photograph from Connecticut Igricultural Experiment Station.) 
overwinter under the shell of the female, hatch in the early summer. Each nymph or crawler moves to a new place, settles after a few days, and inserts its beak into the leaf tissue to feed. It soon begins to make a shell. This species of scale produces two broods of crawlers during the summer.

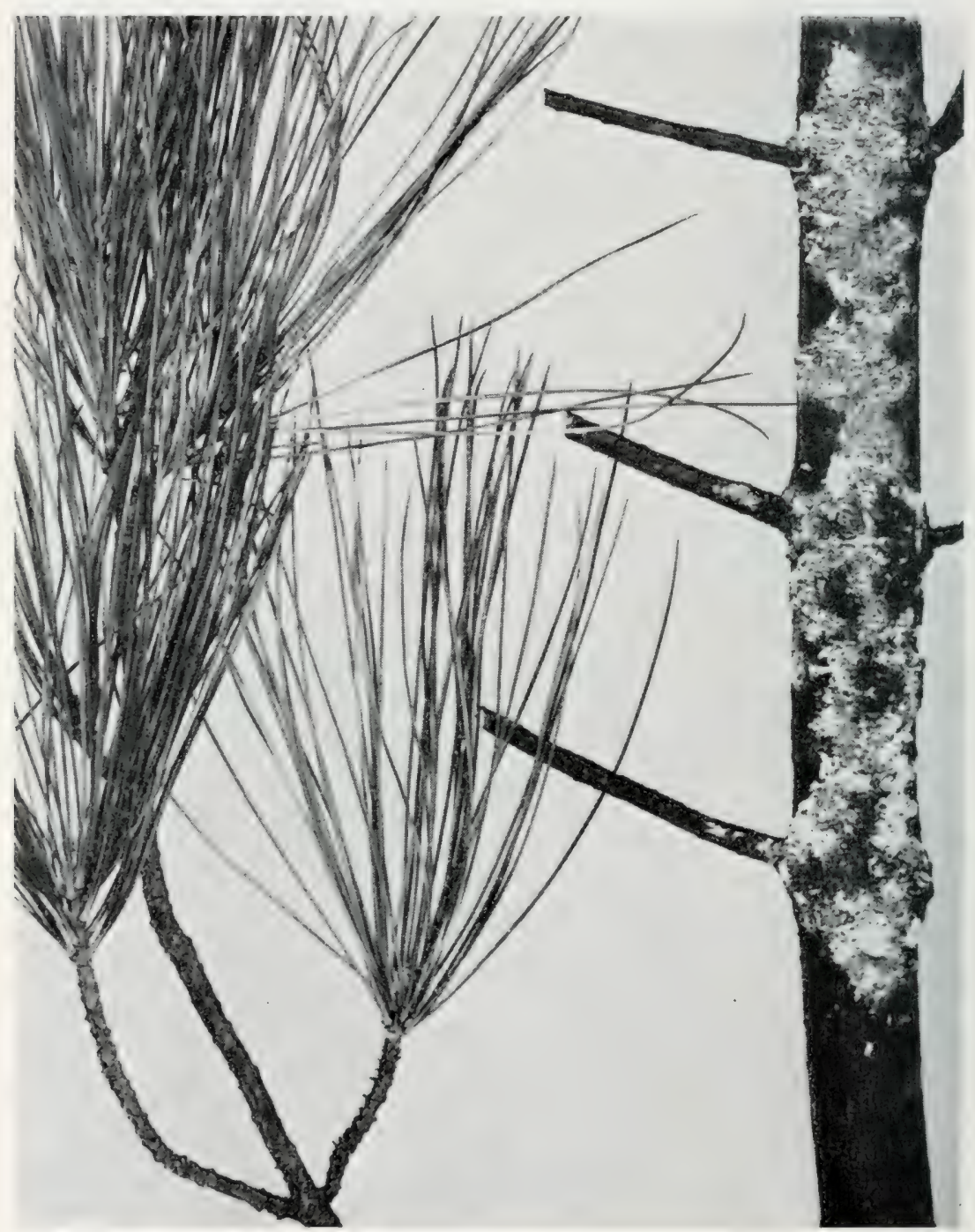

Fig. 41.-Pine bark aphid: infestation on white pine. The aphids themselves are inconspicuous, but an infestation is easily recognized by the splotches of cottony substance they produce. 
Control Measure 12 (end of circular) in winter or Control Measure 3 in June after eggs have hatched.

Pine Bark Aphid, Pineus strobi (Htg.), fig. 41.-White patches of cottony substance on the trunks and limbs of pines make an infestation of this pest easy to recognize. The insect mefers white pine but sometimes feeds on Scotch and Austrian pines. Its feeding does little damage to large, thrifty trees but may weaken young trees.

The immature aphid, which overwinters under the "cotton," matures in the early spring and lays yellowish eggs, which also are covered with "cotton." These eggs hatch in June, producing both winged and wingless forms. The winged form apparently migrates to other pines. The wingless form remains where it was hatched and lays eggs which produce the overwintering nymphs.

Control Measure 3 or 8 (end of circular) applied forcefully in June.

European Pine Shoot Moth, Rhyacionia buoliana (Schiff.).The black-headed, brown larvae of this species may cause serious damage to Mugho, red, and Scotch pines by boring into the shoots, causing them to turn brown and die. The partly grown, overwintering larvae become active in the spring and bore into uninfested shoots; pitch forms at the entrance holes they make. Pupation occurs in early summer, and the female moth, soon after emerging from her pupa, deposits eggs near the tips of twigs. Each young larva bores into the bases of needles to feed; feeding by the larva causes the needles to turn yellow. Later the larva bores into a shoot for the winter.

Control Measure \& (end of circular). Spray applications must be timed to poison young larvae when they are active in mid-April and late June or early July. Removal and destruction of infested shoots in winter may help control this pest.

Nantucket Pine Moth, Rhyacionia frustrana (Comst.), fig. 12.-The small, yellowish larva of this insect is only about onehalf inch long. It may kill many tips of red, jack, and other pines. The adults, reddish-brown moths, emerge in the spring from overwintering pupae. The female deposits flat, yellowish eggs on the needles and terminal leaf buds of pines. The larvae mine the needles at first but later bore down the centers of twigs. They construct delicate webs that enclose the affected needle: and twigs. Larvae of the first two generations per year pupate in buds. 


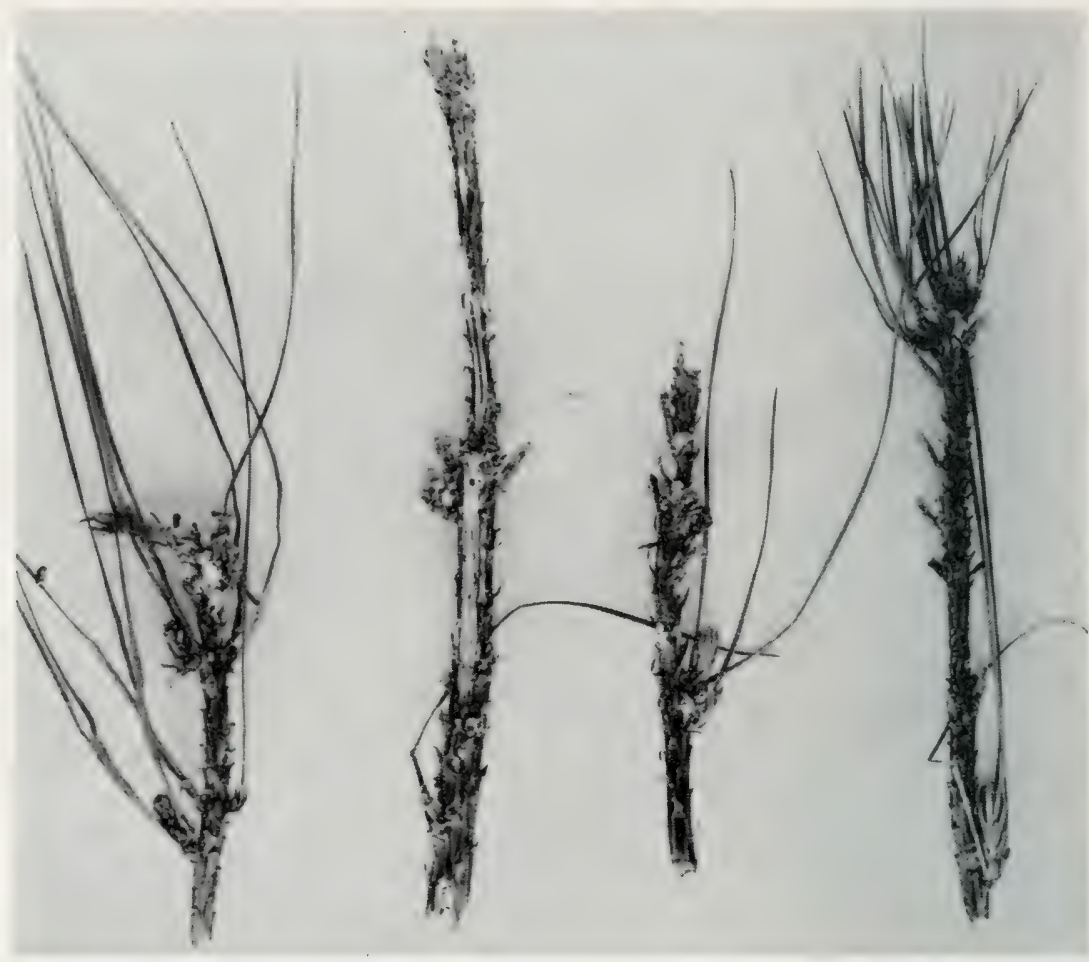

Fig. 42.-Nantucket pine moth: damage to pine shoots by the small, yellowish larvae of this moth. Red pines and jack pines are favored by this pest.

Control Measure? (end of circular). Spray should be applied in mid-April and late June. Infested shoots should be removed and destroyed.

Zimmerman Pine Ioth, Dioryctria zimmermani (Grote).The light gray, reddish-yellow, or greenish larva of this species tunnels under the bark around limbs and branches of pine, especially at the whols, where it does serious damage. Presence of larvae usually can be recognized by the great quantity of pitch over the tunnels. Scotch and Austrian pines are particularly susceptible to this insect.

The maximum flight of the adults, which are nocturnal, clark gray moths, occurs about the middle of August, when the female deposits eggs on the bark of pine. The larvae usually work where bark is thin. Pupation occurs in the larval tunnels.

Contro! .Heasure 1.3 (end of circular) applied in early August. 


\section{POPLAR}

The fast-growing poplars, Lombardy, Carolina, aspen, and cottonwood, are almost certain to be short-lived because of the ravages of borers. Some of these borers are discussed briefly below.

Poplar Borer, Saperda calcarata. Say.-The white, cylindrical larva, which does the boring, and the adults, bluish-gray beetles, are each more than an inch long. Eggs deposited in slits in bark in the summer produce the borers that work under the bark and sapwood and into the heartwood of an infested tree. Frass or sawdust at the base of a tree indicates the presence of borers. Three years are required for the life cycle of this insect.

Control Measure \& (end of circular). Heavily infested trees should be cut down and burned in the early spring.

Cottonwood Borer, Plectrodera scalator (F.).- The adult form of this insect is a large beetle with long, black antennae. The female lays eggs in cavities dug in the bark. The eggs produce white, deeply constricted grubs that when grown are up to 2 inches in length. These grubs, the tunnels of which are plugged with wood fibers, work near the bases of trees or even below ground. Badly infested trees may be easily blown over. Two years are required for the life cycle of this insect.

Control Measure \& (end of circular); or wire screen may be placed around the bases of trees to prevent egg laying.

Poplar and Willow Borer, Sternochetus lapathi (L.).-The larva of this insect is a legless grub or borer, about one-half inch long, that bores into poplars and willows. The adults are black snout beetles or weevils. The borer feeds in the limbs and branches, as well as in the trunk, of the tree it infests. It prefers wood 2 or more years old.

Control Measure \& (end of circular). Infested branches and limbs should be removed and burned before July.

Carpenterworm, Prionorystus mbiniue (Peck).-The larva of this insect is a pinkish, slightly flattened caterpillar, up to $21 \%$ inches long, that develops from an egg deposited in a bark crevice by a large, gray moth. The carpenterworm requires 3 years to complete development, during which time the larva mines and loosens the bark and drills large holes into the trunk of the infested tree. It may deform trees and branches.

Control Measure 4 (end of circular). 
Cottonwood Leaf Beetle, Chrysomela scripta F. - The foliage of cottonwood and willow is often skeletonized by the dirty yellow larvae of this species. The overwintering form, a beetle about one-fourth inch long, has a black head and thorax and yellowish wing covers. In spring, it emerges from the debris about a tree. The female deposits masses of yellow eggs on the under sides of leaves. The larva eats the tissue of leaves, all but the veins, completes development in 2 weeks or so, and, attached to a leaf, pupates with its head hanging downward. This insect probably has two broods a year.

Control Measure 1 or 2 (end of circular).

Poplar Tent Maker, Ichthyura inclusa Hbn. - Silken tents enclosing a branch or twig of a poplar are signs of colonies of the black-mottled cater pillars that are the larvae of this insect. As the caterpillars grow, they take more and more leaves into the tent. The insect overwinters in the pupal stage. The female moth that emerges from an overwintering pupa deposits masses of eggs on leaves to produce caterpillars that feed in June. A second brood of caterpillars occurs in August.

Control Measure 1 or 2 (end of circular) applied when caterpillars are small. Infested branches should be cut out and burned.

Oystershell Scale, fig. 5.-This is a common and destructive pest of cottonwood. See under Ash. Control Measure 5 (end of (ircular) in late winter or Control Measure 3 about the first of June, after eggs hatch. Thorough spray coverage is essential.

\section{PRIVET}

Privet Thrips, Dendrothrips ornatus (Jablon.).-This thrips in both adult and nymphal forms is a small, flat, elongate insect that feeds in great numbers on privet foliage, withdrawing the juices and chlorophyll. The adult thrips, dark brown and yellow, have wings. The nymph, almost colorless at first, becomes lemon yellow as it increases in size. Privet leaves affected by this insect become dotted and dirty with excrement and they fall prematurely. Because this insect feeds at first on the under sides of leaves, it often goes unnoticed until the leaves have been severely damaged.

Control Measure 3 or $\&$ (end of circular) applied in June, or when the thrips infestation occurs. DDT should not be used on privet, as it may cause serious leaf drop. 


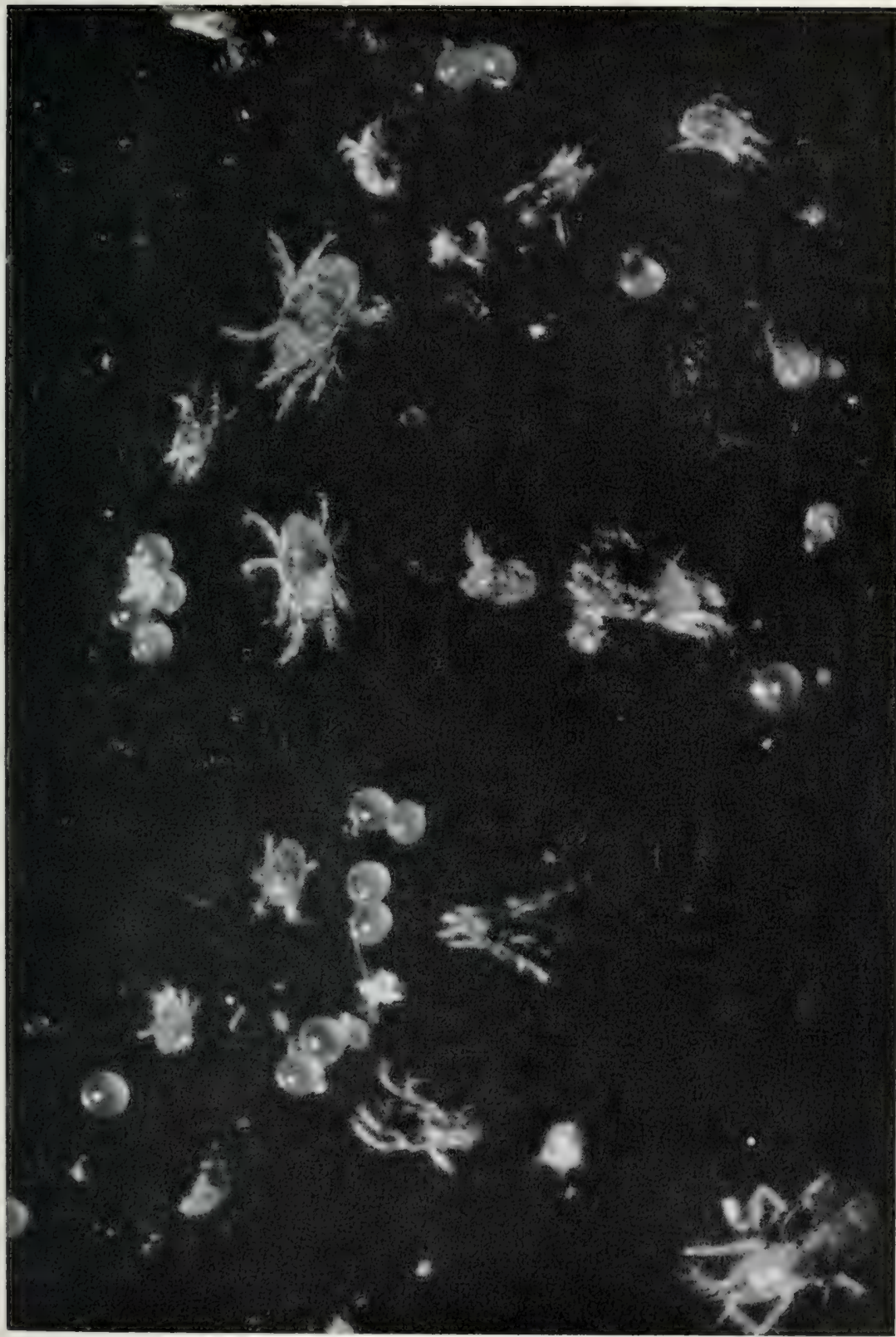

Fig. 43.-Two-spotted spider mite: mites and eggs. The mites, which vary in size with their stages of development, are even in the most advanced stage barely visible to the naked eye. Most of the mites are found on the under sides of infested leaves. 


\section{REDBUD}

Oystershell Scale, fig. 5.- See under Ash. Control Measure 5 (end of circular) in late winter or Contro? Measure 3 about the first of June, after eggs hatch. Thorough spraying is essential.

Two-Spotted Spider Mite, Tetranychus telarius (L.), fig. 43. - The foliage of redbud is sometimes infested with great numbers of green or yellowish mites of this species. The mites remore so much chlorophyll and juice from the foliage that the leaves become dry and drop prematurely. The overwintering female mites move to the leaves in early summer to feed and deposit translucent, spherical eggs. Six-legged larvae hatch from the eggs in a few days. After the first molt, the mites have eight legs. Following two more feeding periods and molts, the mites become adult. The mites of various stages differ in size but are similar in appearance. Nales are slightly smaller than females, and their abdomens are more pointed than those of females. There may be a number of generations of this mite during the summer.

Control Measure 9 (end of circular).

\section{SPIREA}

Spirea Aphid, Aphis spiraecola Patch, fig. 44.-This green plant louse occurs nearly every spring in great numbers on the tender shoots of spirea. Eggs deposited on spirea in the fall give rise to mother aphids that produce living young in the spring. Wingless and winged forms may be present; the latter migrate to other host plants as the plant growth hardens. Quantities of sticky honeydew are produced by an infestation of this aphid.

Control Measure 3 (end of circular).

\section{SPRUCE}

Spruce Spider Mite, Oligonychus ununguis (Jac.).-The spruce spider mite is small, but its dense populations can do a great deal of damage. It is one of the most troublesome pests of arborvitae, spruce, and juniper. It lives on the juices of these plants. When the sharp green color of the foliage begins to give way to gray, and later brown, it is too late to prevent some degree of damage, but prompt action may prevent serious damage or death of the plants. 
Overwintering eggs at the bases of the needles of infested plants produce tiny, light green mites in early spring. Through a series of molts the mites mature into larger, darker green, or almost black individuals, with spinelike hairs that curve back-

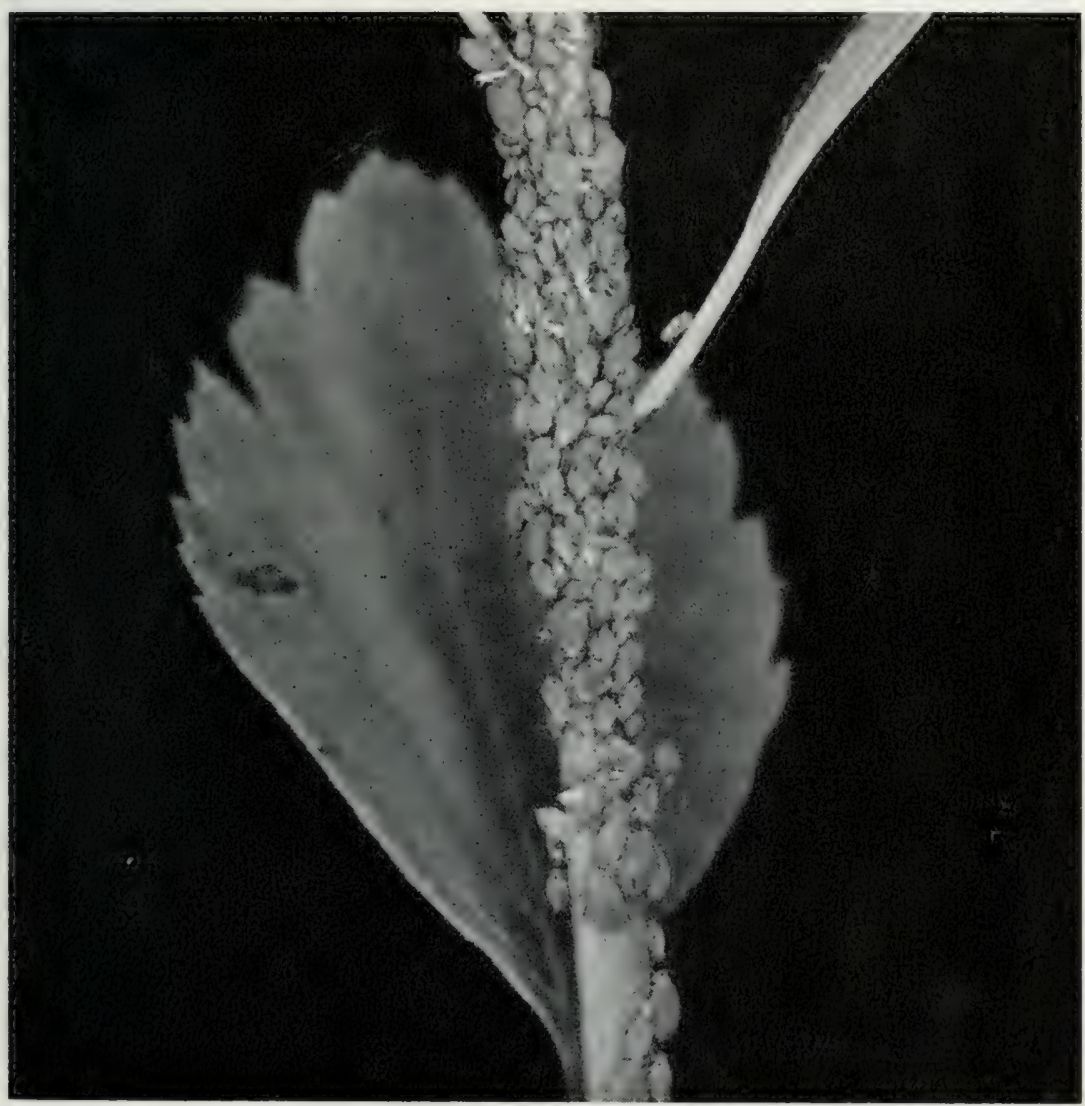

Fig. 44.-Spirea aphid: infestation of this green plant louse on a spirea shoot. After sucking sap from the shoots of spirea for a short time in spring, this aphid develops a winged form that migrates to other host plants.

ward over their robust bodies. The mites can be seen as moving specks on a white piece of paper or dish that has been held under infested branches struck sharply with the hand. This species has a number of generations in a season.

Control Measure? (end of circular) as soon as mites are detected, usually in April or May. 
Cooley Spruce Gall Aphid, Chermes cooleyi Gill._Gall aphids of this species produce thick, elongate galls at the tips of twigs of colorado blue spruce, Sitka spruce, and Engelmann spruce. The galls are so heary that usually they cause the twigs to bend. In midsummer, the galls open and the aphids emerge. Some of the gall aphids develop wings. Gall aphids of the winged form migrate to Douglas fir, where the females lay eggs. The eggs and young gall aphids are covered with patches of cottony wax. No galls develop on Douglas fir.

Eastern Spruce Gall Aphid, Chermes abietis L.-Gall aphids of this species produce somewhat pineapple-shaped galls near the bases of spruce twigs. Sometimes these gall aphids cause severe damage to Norway spruce.

Control Measure 8 (end of circular) in late September or October or in early spring.

Spruce Bud Scale, Physokermes piceae (Schr.), fig. 45.-The mahogany-brown, globular scales of this species cluster at the

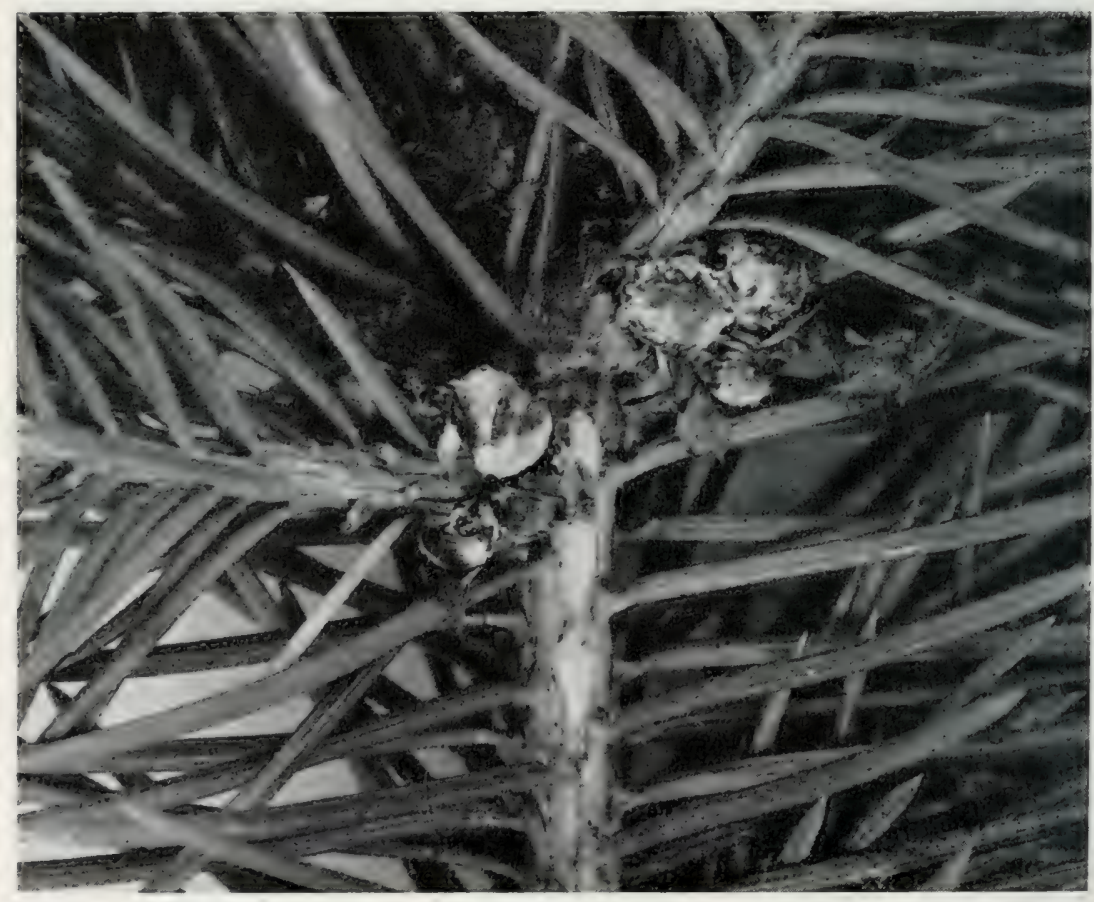

Fig. 45.-Spruce bud scale: infestation on spruce. The globular, mahogany-brown scales resemble spruce buds and are difficult to detect. 
buds and nodes of spruce. The overwintering female fills her shell, about one-eighth inch in diameter, with purple eggs in June. In central Illino:s, the eggs hatch about the first of July. The flat, purple crawlers move away from their mother to settle in a new place.

Control Measure 3 (end of circular) July 10-15.

Spruce Budworm, Choristoneura fumiferana (Clem.).-A destructive forest pest that sometimes attacks ornamental spruces, the larva of this species is a dark reddish-brown caterpillar about 1 inch long when grown. It feeds on the opening buds and needles, tying them together with silk.

The overwintering caterpillar becomes active in the spring and completes development. The adults, dull gray moths, emerge from the pupal case in midsummer, when the female deposits masses of overlapping, greenish eggs on the needles.

Control Measure? (end of circular) when caterpillars are actively feeding.

Pine Needle Scale, fig. 40.-See under Pine. Control Meas"re 12 in winter or Control Measure 3 in June (end of circular).

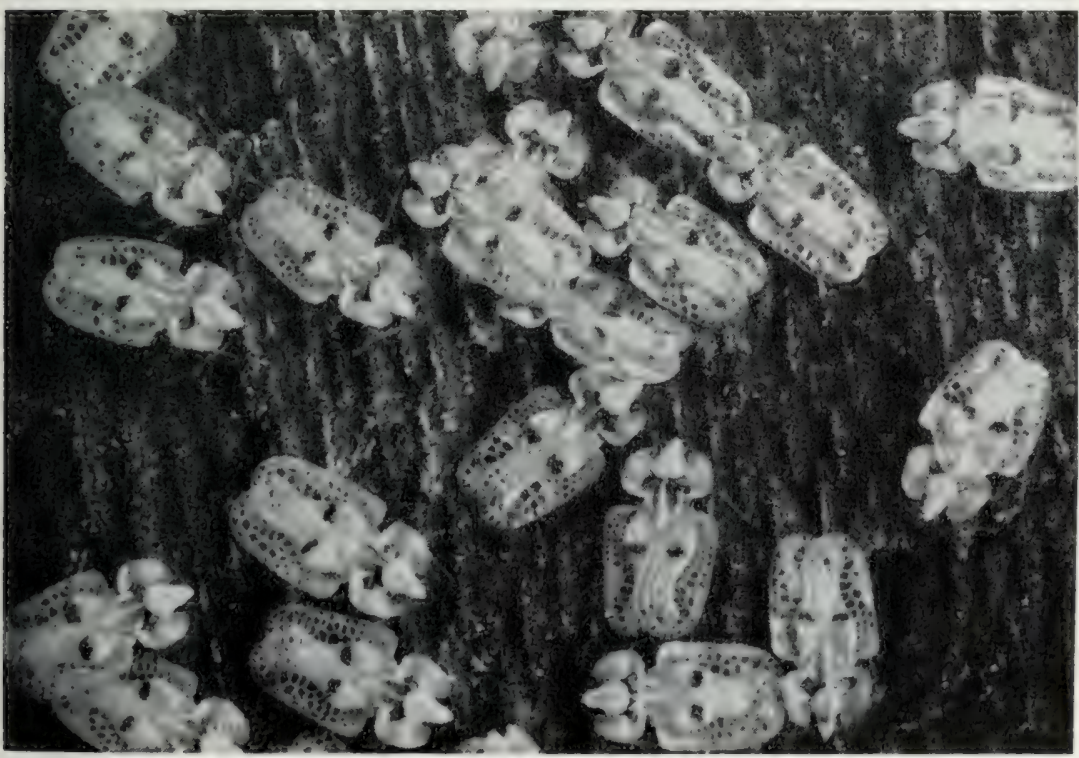

Fig. 46.- Sycamore lace bug: adults. The bugs, which are black and have almost transparent wings, are shown congregated on the bark of a tree. They have sucking mouthparts and feed on the under sides of leaves. (I'hotograph from Connecticut Igricultural Experiment Station.) 


\section{SYCAMORE}

Sycamore Lace Bug, Corythucha ciliata (Say), fig. 46.-This insect is probably the most common pest of sycamore. Both adults and nymphs feed on the under sides of the leaves in great numbers, withdrawing so much plant juice and chlorophyll that the foliage becomes pale and dry. The leaves become dirty with excrement. Both male and female are pretty insects; each is about one-eighth inch long and has a black body and almost transparent, lacelike wings held flat when at rest. By contrast, the black, spiny nymph is ugly.

The overwintering female becomes active in early spring and deposits eggs on the under sides of new leaves. The eggs hatch in a couple of weeks, and each nymph molts five times before becoming an adult, 30 to 40 days later.

Control Measure 3 (end of circular) when the nymphs appear, usually in late May.

Bagworm, fig. 2.- This, the most common leaf eater on sycamore, is discussed under Arborvitae. Control Measure 1, 3, or 11 (end of circular) as soon as the eggs hatch. Sprays applied in late summer after the larvae stop feeding, or during the winter, are ineffective. The worm infestation can be reduced by picking and burning the overwintering bags.

Borers.-Newly set sycamores, like most other newly set trees, are subject to attack by borers, especially the flatheaded apple tree borer, fig. 34. Control Measure \& (end of circular).

\section{TULIPTREE}

Tuliptree Scale, Toumeyella liriodendri (Gmel.).-Oval, brown females of this species may be seen plastered on the bark of lower branches and twigs of the tuliptree in summer. Great quantities of honeydew drip from the scales. Each scale is more than one-fourth inch across. Inconspicuous overwintering nymphs, also plastered on the bark, grow rapidly in the spring and early summer. The female reaches maturity in August and apparently gives birth to living young.

Control Measure 5 (end of circular) in late winter.

Tuliptree Aphid, Macrosiphum liriodendri (Monell).-This small, greenish aphid occurs in great numbers on the under sides of the leaves of the tuliptree. Honeydew, which is secreted 
in large quantities by the aphids, makes the leaves sticky and drips on objects under the tree. Sooty mold often grows in the honeydew and causes the leaves and other objects it covers to appear black.

Control Measure 3 (end of circular).

\section{WALNUT}

Walnut Caterpillar, Datana integerrima G. \& R., fig. 47.The larva of this species, a large, black caterpillar with gray

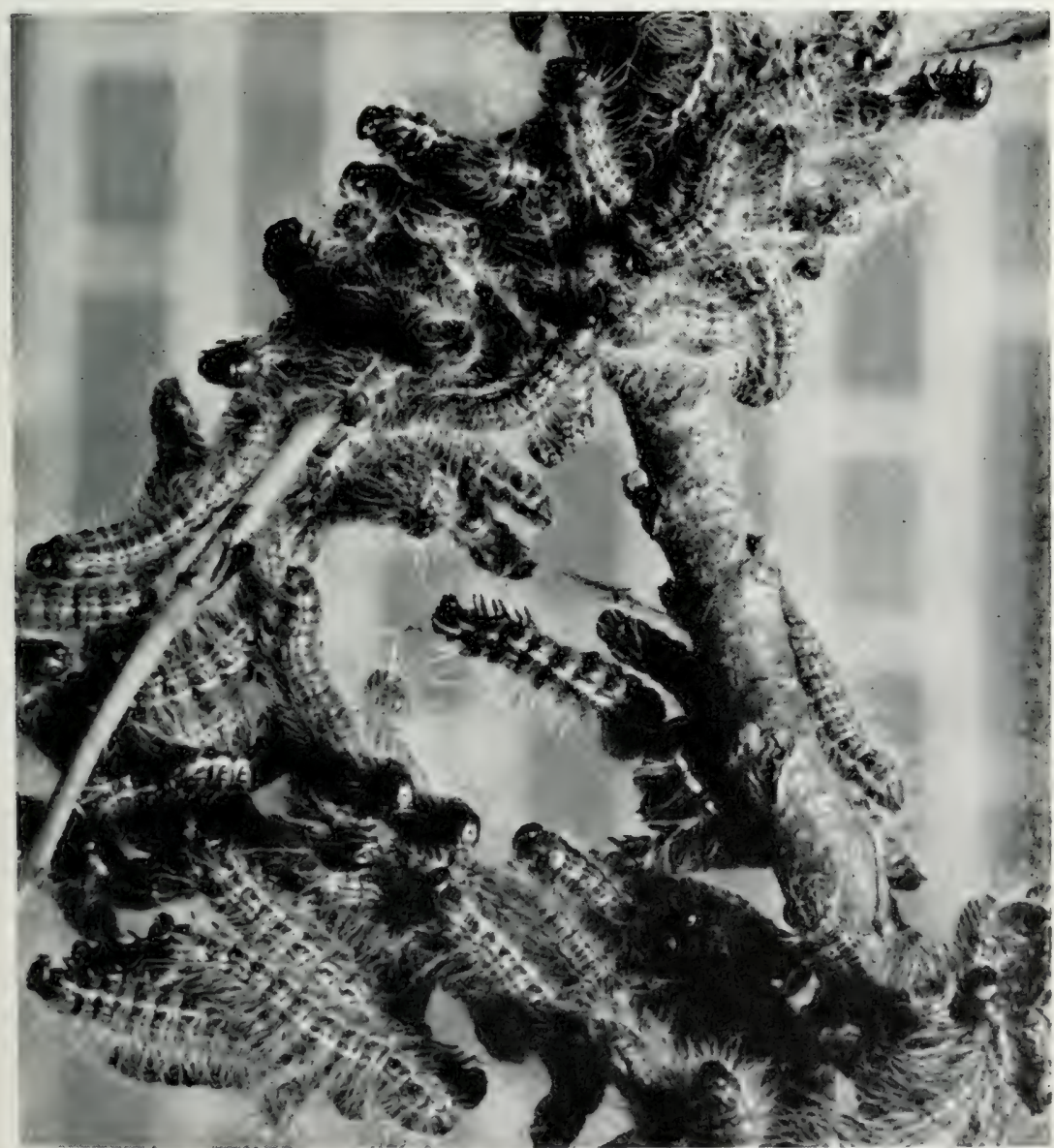

Fig. 47.-Walnut caterpillar: a colony of larvae. Walnut caterpillars, reddish when small, later have black bodies covered with white hair. They may completely strip the foliage from the trees they infest. 
hatis, is the main leaf eater of walnut trees and, for some unknown reason, is attracted to isolated trees. It is very fond not only of walnut but of butternut, hickory, oak, honey locust, and willow: sometimes it feeds on apple and other fruit trees. Each (aterpillar develops through a series of molts from one of many eggs laid in masses on leaves of the host tree. An egg mass produces a colony of caterpillars that may destroy the foliage on a

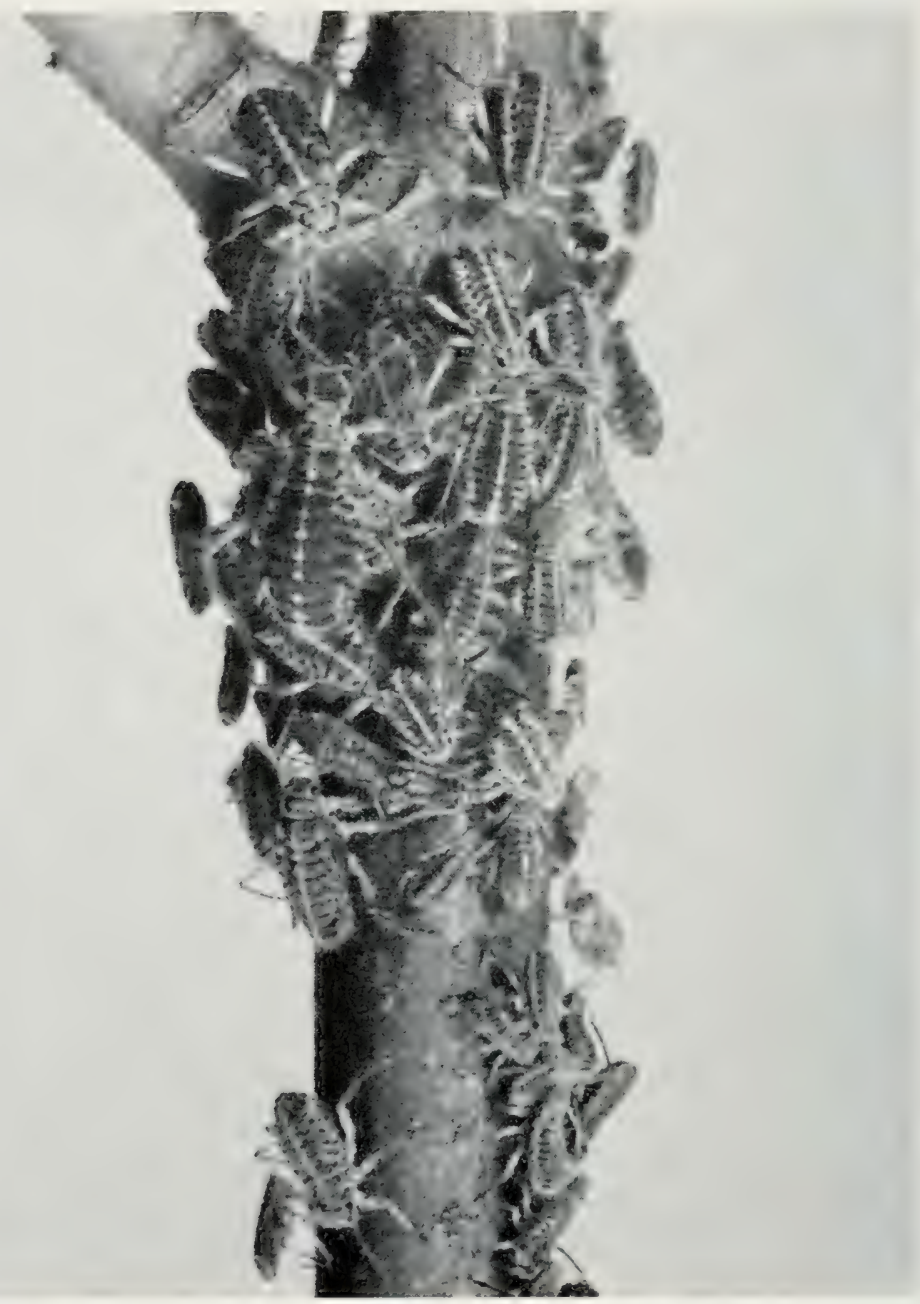

Fig. 18.-Willow aphid: an infestation of the wingless form on a twig. This duskv, relativelv large aphid withdraws juices from leaves, causing them to wilt and drop. 
whole limb before moving to fresh leaves. The colonies migrate downward on a limb or tree trunk, molt, and leave a clump of skins the size of a man's fist. When grown and about 2 inches long, the caterpillars leave the infested tree and dig into the soil. There they pass the winter in the pupal stage. The adults, brownish moths, emerge in early summer. The female flies into one of the preferred kinds of trees, where she deposits eggs.

Control Measure 1 or 2 (end of circular) just as soon as feeding can be detected. Bands of sticky material around tree trunks are of no benefit.

Black Walnut Curculio, Conotiachelus retentus (Say).-This reddish-brown weevil feeds on tender shoots and foliage of walnut for a while in the spring. The adult female makes in the young walnuts crescent-shaped cuts in which she deposits eggs. Feeding of the larvae that hatch causes the nuts to drop when only about half grown.

Control Meusure 1 (end of circular) applied to new foliage. Fortunately this walnut pest is attacked by several parasites, which help keep it under control.

\section{WILLOW}

Willow Aphid, Clavigeres smithiae (Monell), fig. 48.-This rather large, dusky aphid may infest twigs and leaves of willows during the summer. Unlike many kinds of aphids, this one is restless, easily disturbed, and rapid in its movements. Both winged and wingless forms may be present on an infested tree. By withdrawing juices from leaves, this aphid may cause the leaves to wilt and drop.

Control Measure 3 (end of circular).

Bagworm, fig. 2.- See under Arboritae. Control Heasure 1, 3, or 11 (end of circular).

Borers.-See under Popler. Control Measure $\&$ (end of circular).

Oystershell Scale, fig. 5.-See under Ash. Control Metsure 3 or 5 (end of circular).

\section{YEW (TAXUS)}

Black Vine Weevil. Brachylhimus sulcutus (F.), fig. 49.Rapid dying of yew-dying similar to that caused by transplant- 
ing shock-may indicate that the roots have been eaten by the white, legless, crescent-shaped grubs of the black vine weevil. The grubs feed on plant roots from late summer until late spring. Development and transformation of this insect take place in the soil, and the adult weevils make their way to the surface about the first of June. The adults are seldom observed, as they hide during most of the daylight hours and feed sparingly, mainly at night, on the foliage toward the center of the plant. The female does not deposit her eggs on a plant, as many insects do, but simply drops them on the ground. This insect has only one generation a year. A long preoviposition period makes it possible to time a control spray to kill all adults after they have emerged from the soil and before they have dropped eggs.

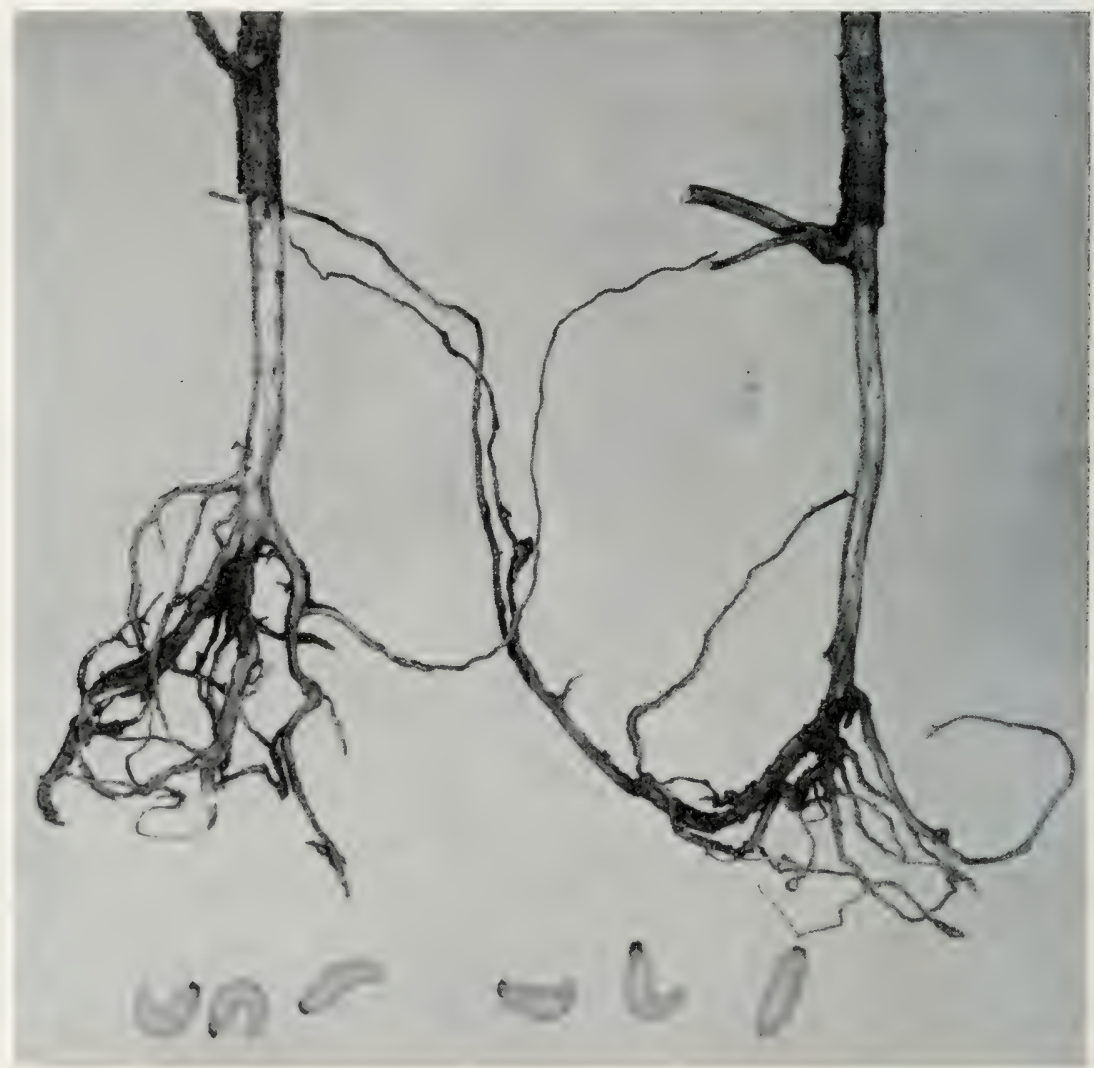

Fig. 49.-Black vine weevil: larvae and damage to small yews. The adult, a black snout beetle, is seldom seen. 


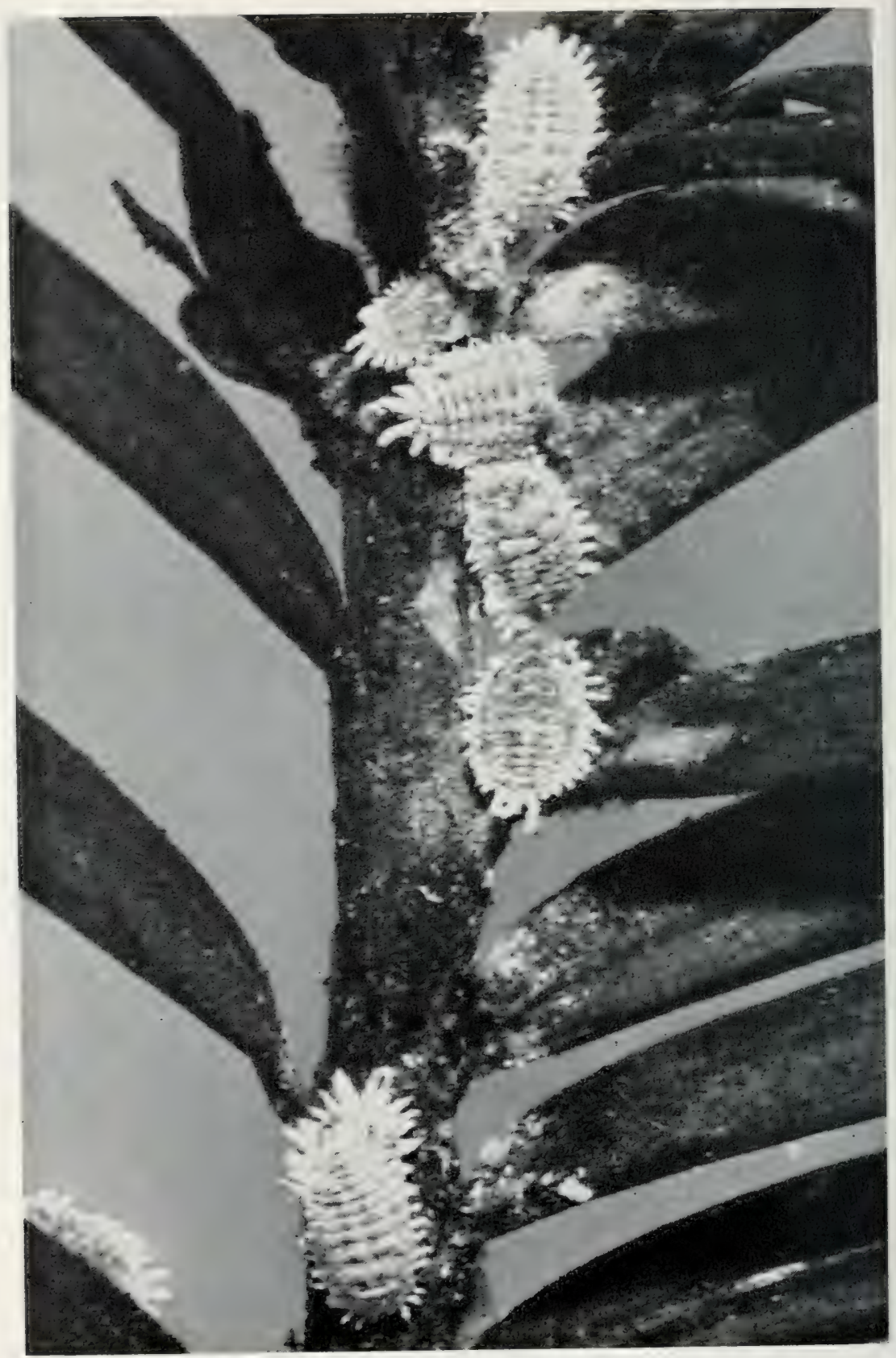

Fig. 51.- Taxus mealybug: infestation on yew. The sooty mold on infested needles makes the white, wingless insects conspicuous. 
the bark and cambium and may girdle and kill a branch or an entire plant.

Control Measure 17 (end of circular).

Taxus Mealybug, Dysmicoceus cuspidatue (Rau), fig. 51.The taxus mealybug is an occasional pest of yew. Its name is iescriptive of the white, waxy, slow-moving, sucking insect seen reeding in small colonies on the twigs and branches.

Control Measure.3 (end of circular). The spray should be applied with force and repeated in 2 weeks.

\section{POTENTIAL INSECT ENEMIES}

There are several important shade tree pests that have not ret, but may, become destructive in Illinois. Everyone should be on the alert for them. Anyone finding an insect fitting one of the
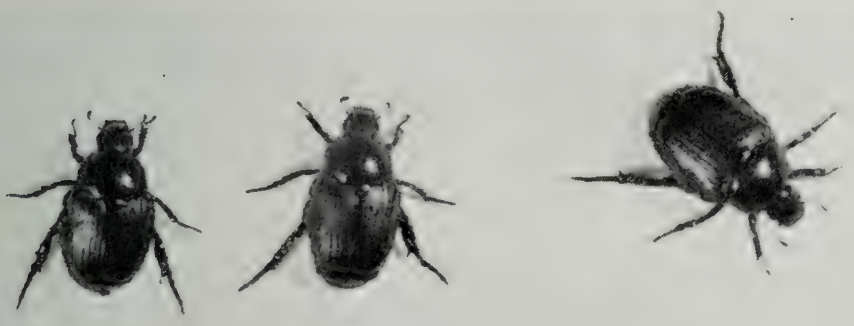

Fig. 52.-Japanese beetle: adults. Both male and female adults are principally metallic green in color and about a half inch in length. Each has white spots on the tip of the abdomen.

descriptions below should place the insect in alcohol and send it to the Illinois Natural History Survey, Urbana. Early knowledge of the presence of a new pest may result in holding down an infestation or in wiping it out completely.

Japanese Beetle, Popillia japonica Newm., fig. 52.-The Japanese beetle feeds on the foliage of a wide variety of trees, shrubs, vines, and other plants. It is a ravenous feeder that occurs in great hordes.

A native of the Orient, this insect was first found in the United States in 1916, and isolated infestations now occur in Illinois. The adults, metallic green beetles about one-half inch long, have white spots on the tips of their abdomens, just back 


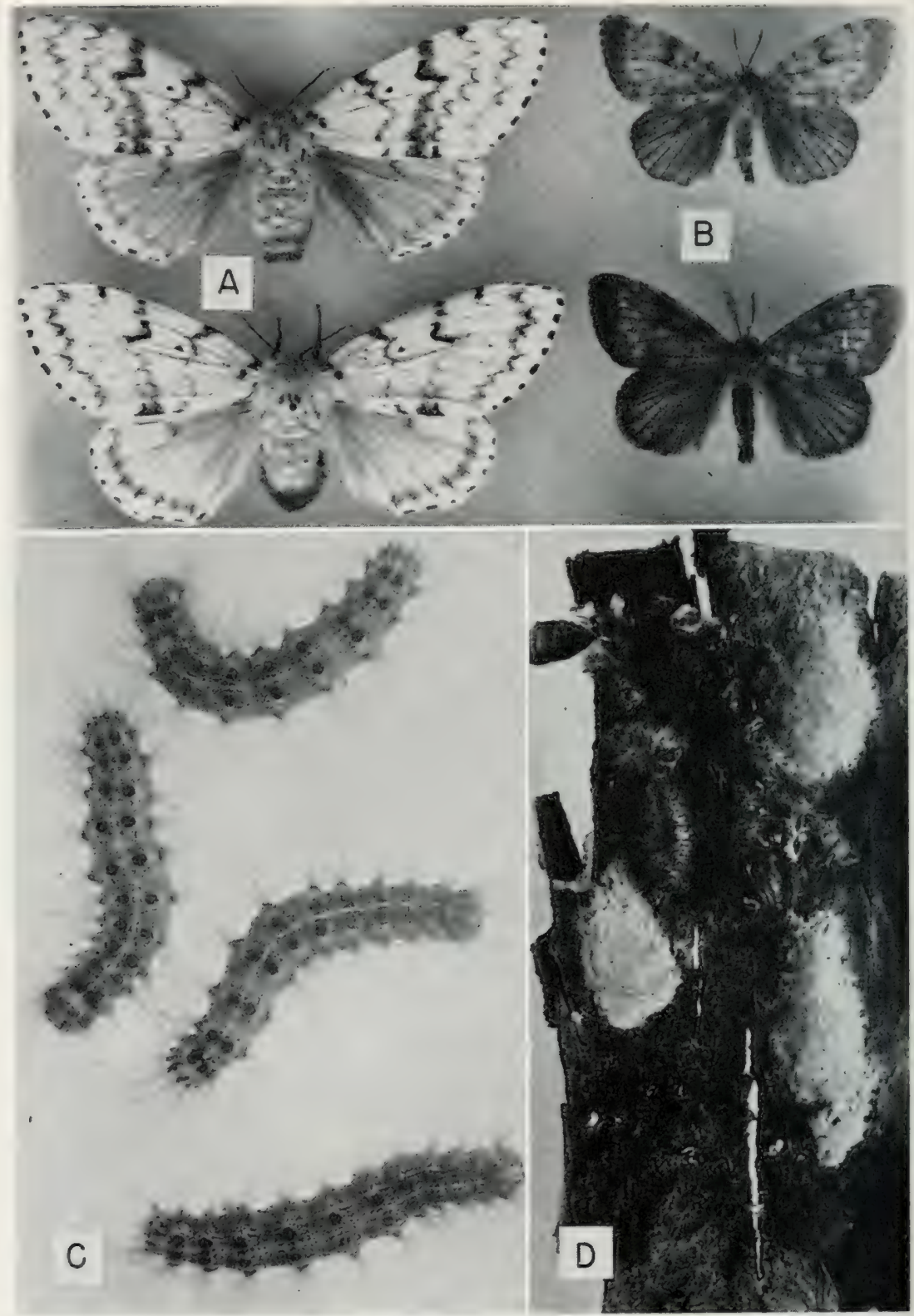

Fig. 53.-Gypsy moth: $A$, adult females; $B$, adult males; $C$, larvae; $D$, egg clusters and pupae on the under side of loose bark. The female is buff in color, the male dusky; the larva is covered with brown hair and has blue and red tubercles along the back. The egg clusters are covered with tan hairs. (Photographs from (onnecticut Agricultural Experiment Station.) 
of the wing covers. They are strong fliers. They are very fond of eating ripening apples, corn silk, grape foliage, and soybeans. The female deposits eggs in the soil to produce grubs that feed on the roots of grasses. The grubs spend the winter in the soil, resume feeding in the spring, complete growth, and pupate. The adults emerge from the pupae in late June or July and feed for several months. This insect produces one generation each year.

Gypsy Moth, Porthetria dispar (L.), fig. 53.-Of all the leaffeeding pests that attack shade and woodland trees, the caterpillar of the gypsy moth is the most destructive. It feeds on nearly all deciduous trees, and, except in the early stages of its development, on many evergreens. Most of the area infested by this insect lies east of the Hudson River. An infestation in Michigan was discovered recently, but there is good prospect of eradicating it.

The female moth deposits eggs in hair-coated clusters on tree trunks, buildings, and other objects. The full-grown caterpillar, 2 to $21 / 2$ inches long, is covered with tufts of long brown hair and has five pairs of blue tubercles along the back followed by six pairs of red tubercles.

The insect overwinters in the egg stage. The eggs hatch as the leaves of trees unfold in spring. The caterpillars feed for about 2 months, during which time they may strip trees of their foliage. Pupation occurs in cocoons fastened to tree trunks. The cidults emerge in late July, and the female deposits the eggs that carry the species through the winter. The female is buff in color, the male brown.

Brown-Tail Moth, Nygmia phaeorrhoea (Donov.).- The caterpillar of this species feeds on the foliage of a wide variety of trees, including oak, elm, maple, willow, apple, pear, and plum. Like the gypsy moth, the brown-tail moth is confined mainly to the New England states.

The male as well as the female is white, except on the tip of the abdomen, which is covered with brown hairs. The caterpillar is reddish brown and has a broken yellow stripe along each side of its body. The body is covered with stiff barbed hairs, which may cause a very irritating rash on human beings.

The partly grown caterpillar, which overwinters in a nest of webbed leaves, feeds for a while in the spring before pupating. The adults emerge in July, and the female deposits masses of brown eggs on the under sides of leaves. 


\section{ABOUT INSECTICIDES}

Insect control sometimes is based on the division of insects into two groups: those with chewing mouthparts and those with sucking mouthparts. A stomach poison is usually prescribed for those with chewing mouthparts, a contact poison for those with sucking mouthparts.

Lead arsenate is an example of a stomach poison and nicotine sulfate an example of a contact poisor. DDT and malathion may act as either or both types of poison. This statement does not mean that all insects can be controlled with DDT or malathion. For example, while DDT is effective against a wide variety of caterpillars, it does a poor job on bagworms. Unfortunately, DDT kills many beneficial insects - those that prey on pestsand thereby sometimes contributes to unusually heavy mite, aphid, and scale infestations.

Many insecticides are available to the person wishing to control insect pests of trees and shrubs. The trend is toward a specific insecticide for a specific pest. However, the number of insecticides recommended in this circular has been kept as low as possible, consistent with practical usage and effective results.

The formulations recommended on pages 90-92 are for types of sprayers shown in figs. 55-58 and the frontispiece. Formulations for the mist blower, fig. 59, may require special consideration. A general rule to follow in formulating for the mist blower is to multiply by six the quantity of insecticide recommended for the hydraulic sprayer. Insecticide solut. ons or emulsions are handled by mist blowers better than are wettable powders in suspension. However, wettable powders mixed with water can be used in a mist blower with suitable nozzle adjustment and adequate agitation in the tank.

All insecticides should be handled as poisons. Some are more poisonous to human beings than are others, and some are so hazardous that they should be handled only by persons familiar with them. The first step in handling all insecticides safely is to read the label on the package, and the second is to follow the instructions given thereon.

Although insecticide applications are depended upon for the control of most insect pests of trees and shrubs, other measures are sometimes used: syringing mite infestations on plants with a strong stream of water; picking and burning the overwintering 
bags of bagworms to destroy the eggs; covering young trees with cheesecloth to protect them from cicadas; wrapping the trunks of young trees with paper to protect them from borers, fig. 54 .

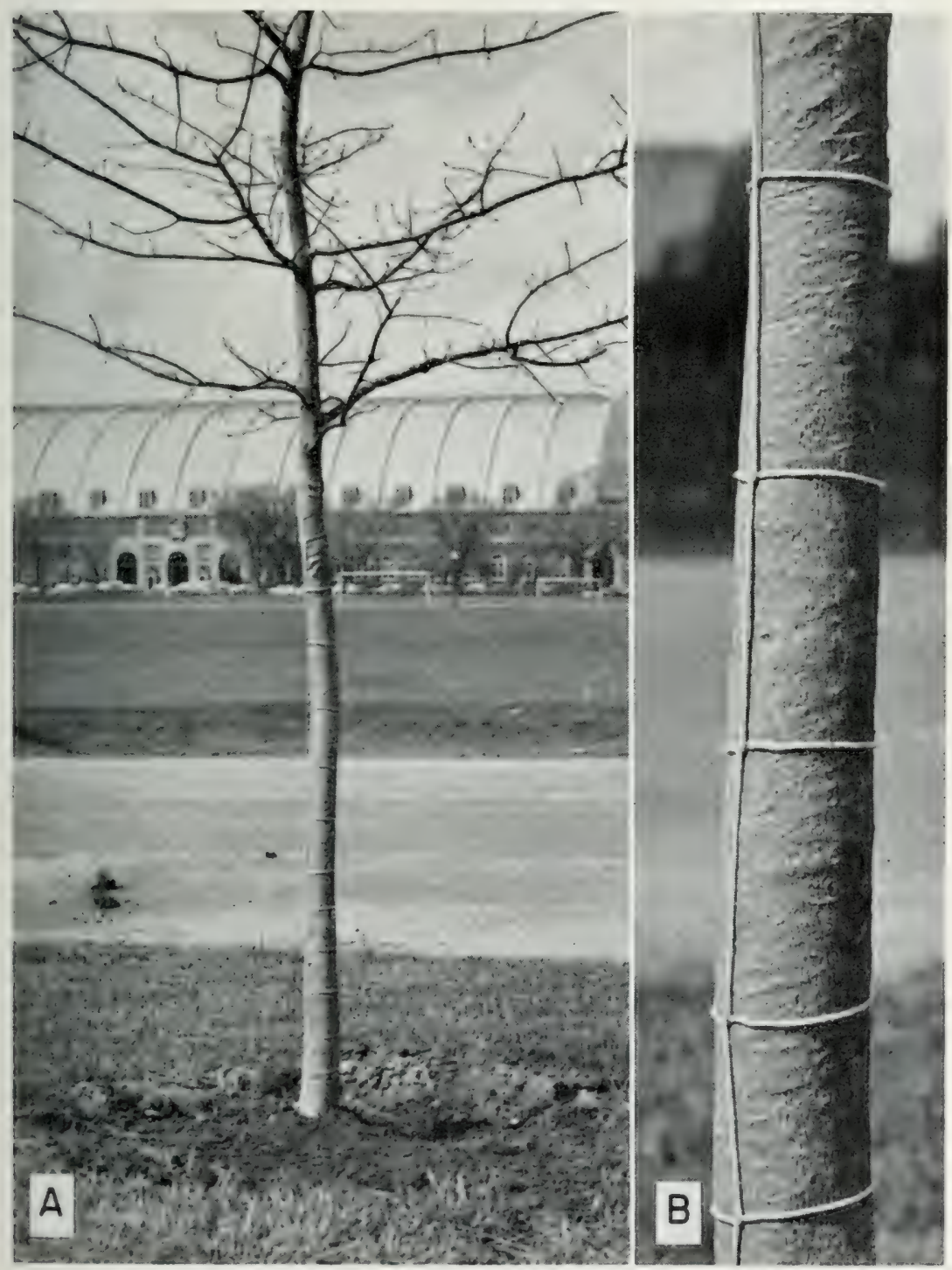

Fig. 54.-Newly set tree, 4 , wrapped with paper to prevent damage by borers. The paper, about 4 inches wide and specially designed for wrapping trees, is spiraled about the trunk of the tree and held in place with a stout cord, as shown in $B$. 


\section{ABOUT SPRAY EQUIPMENT AND ITS USE}

A 2- or 3-gallon knapsack sprayer, fig. 55, is the smallest equipment suitable for spraying shrubbery and small trees. The low pressure and low rate of discharge of such equipment demand

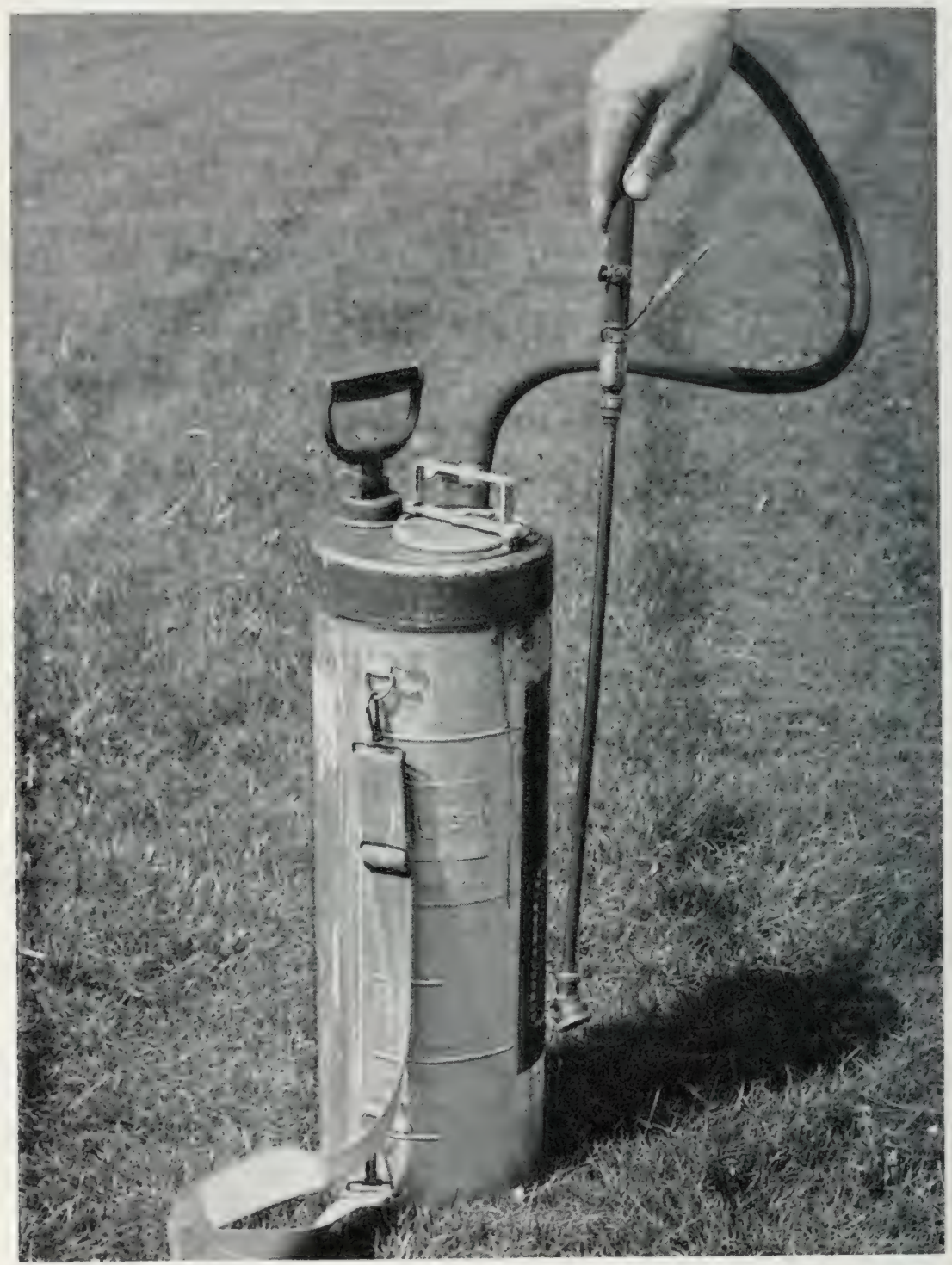

Fig. 55.-Compressed air sprayer, a convenient sprayer for small jobs. 
careful work for complete plant coverage. The trombone-tyle sprayer, shown in the frontispiece, develops adequate pressure and is convenient for spraying a few shrubs and small trees. The bucket-pump sprayer, fig. 56, also derelops adequate pressure for

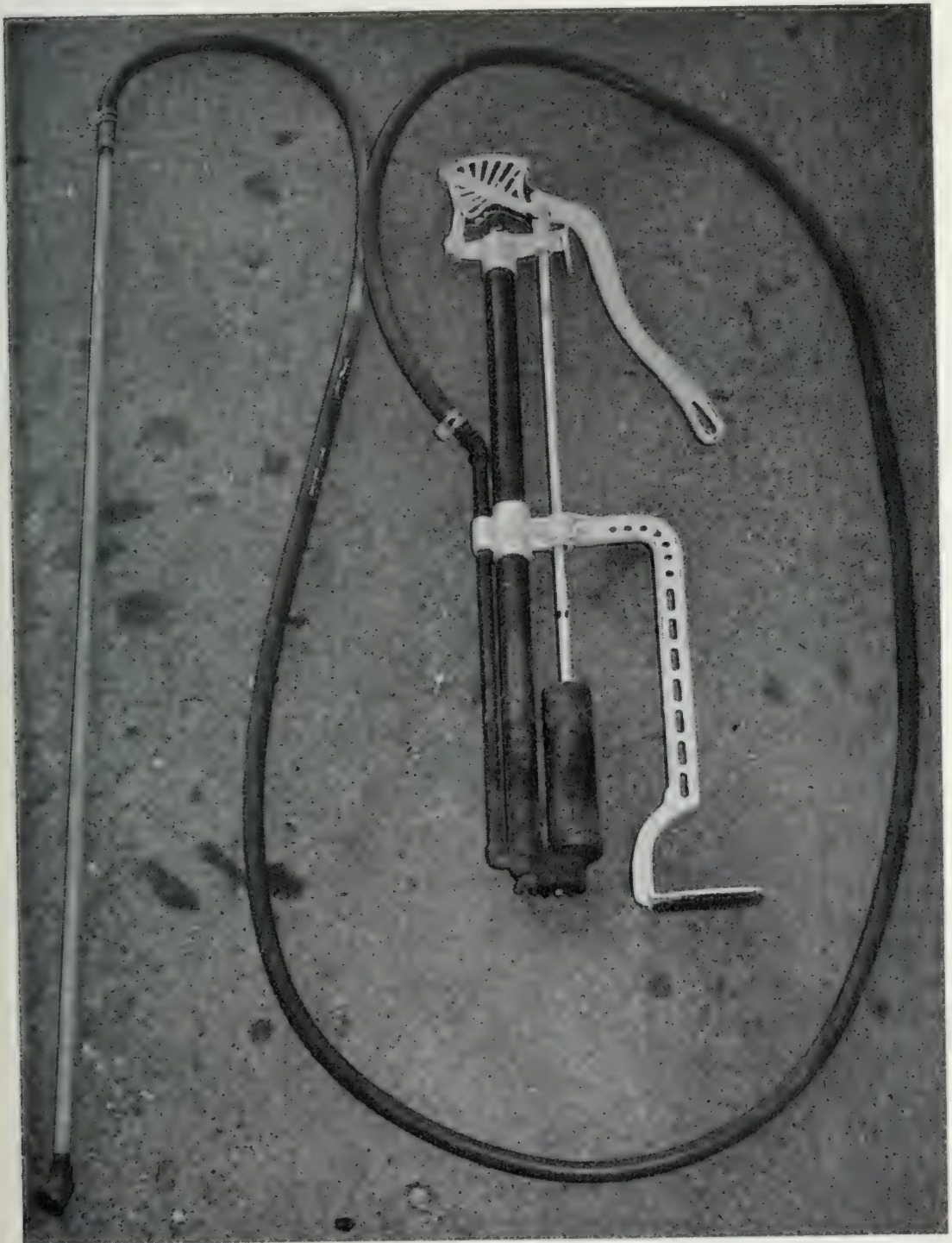

Fig. 56.-Bucket-pump sprayer, an inexpensive but suitable sprayer for shrubs and small trees. The spray material is mixed with water in a bucket and kept mixed by agitation with a wooden paddle. 
small trees and is useful for treating a larger number of plants. A hand-operaterl wheelbarrow-type splayer or small power sprayer, fig. 57, is recommended for any job involving medium-sized plants or a large number of small plants.

Adequate spraying of large trees requires power equipment. A conventional hydraulic sprayer, fig. 58, that develops 500-600

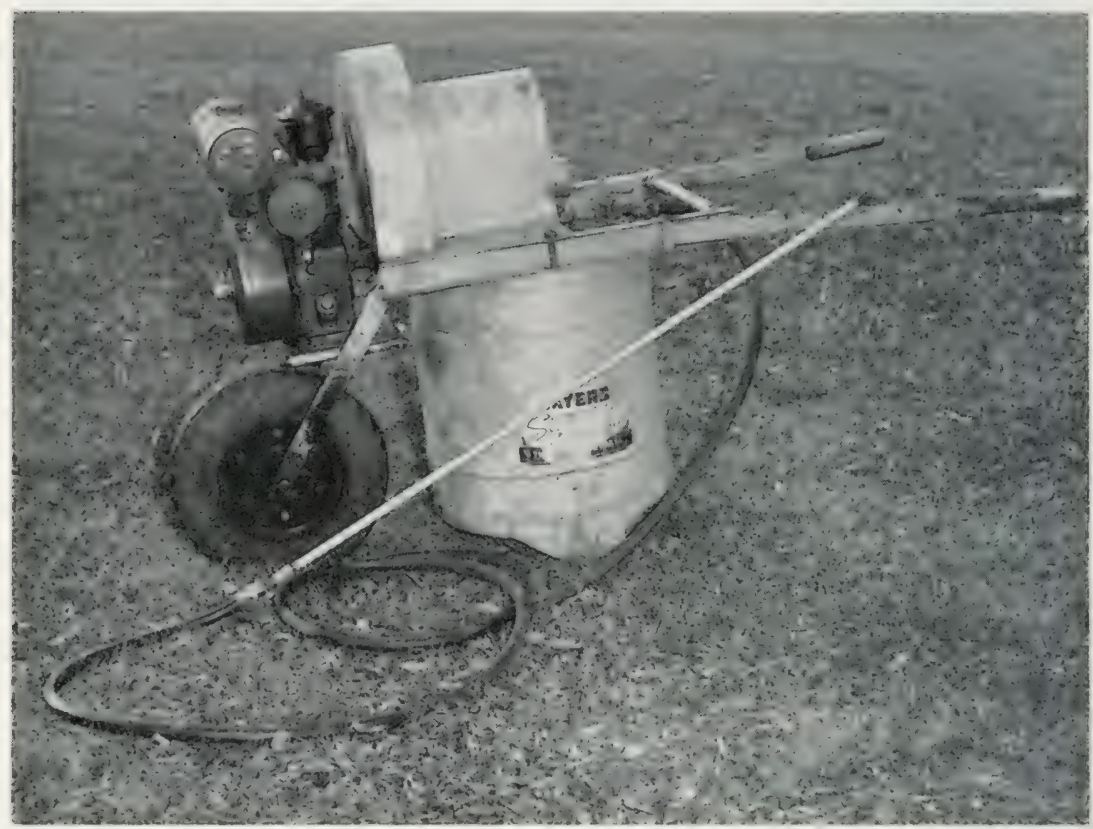

Fig. 57.-Small power sprayer. This is a satisfactory sprayer for shrubs and small trees.

pounds pressure and has a pump that delivers 30-40 gallons per minute is suitable for spraying large trees. However, if all the spraying is done from the ground, a great deal of spray will be wasted in trying to reach the tops of tall trees. Waste can be reduced if some of the spraying is done from a tower built on the sprayer.

A mist blower, fig. 59, is more suitable than a hydraulic sprayer for use with large trees. In the mist blower, a spray concentrate is discharged into a blast of air that travels through an outlet at a velocity of 100-120 miles per hour. The outlet can be manipulated to direct the spray concentrate to all parts of even large trees. 
Incomplete spray coverage of a tree may serve to check the ravages of a leaf eater, such as the cankerworm, but control of scale insects or control of the bark beetle that transmits Dutch elm disease requires complete coverage. This is difficult to obtain even with the best of equipment. The tree must be sprayed systematically from many angles and at a time when the wind velocity is essentially zero. Careful inspection of a tree or shrub after spraying shows whether proper coverage has been obtained.

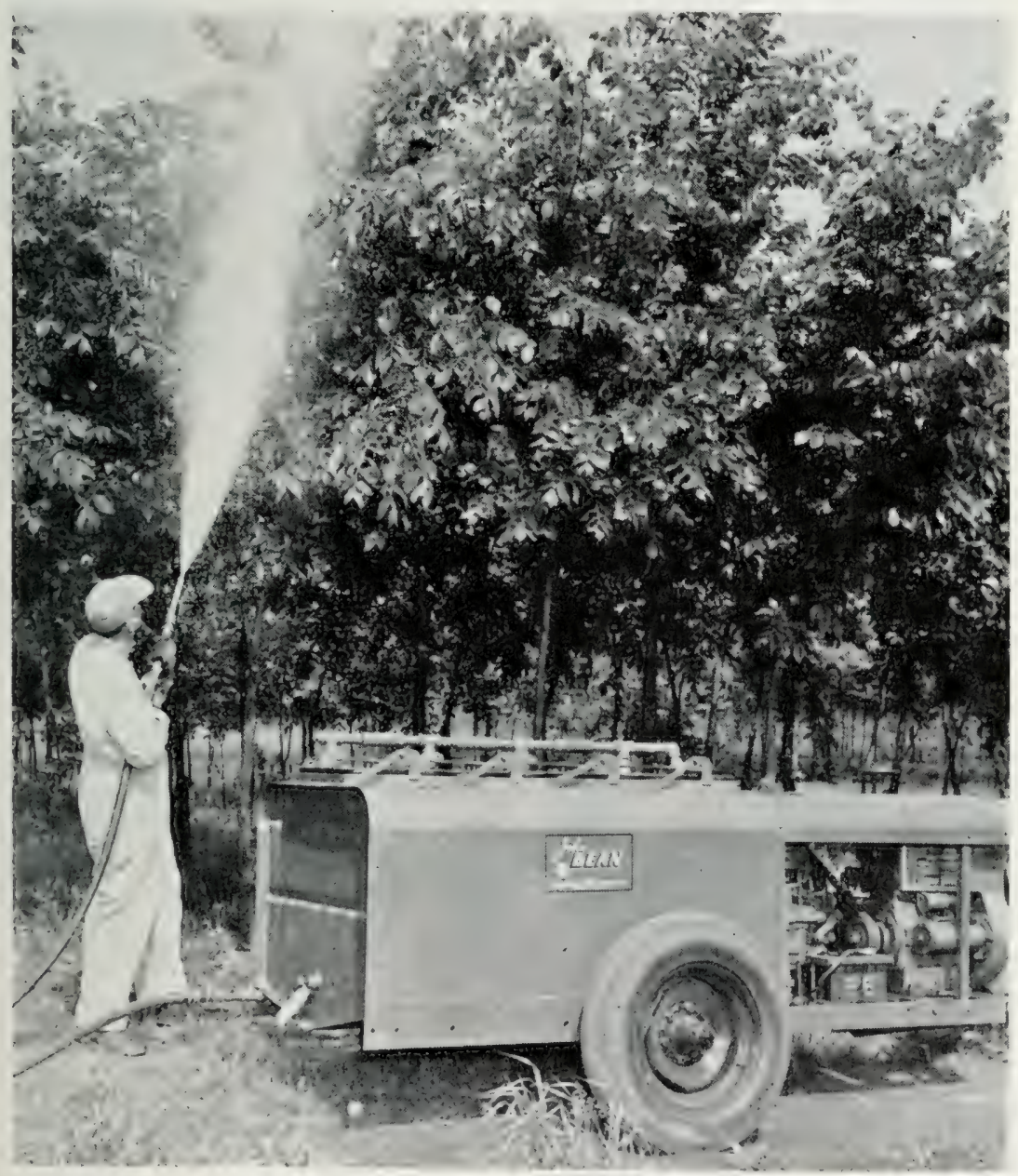

Fig. 58.- Power sprayer in operation. This machine, known as a hy draulic sprayer, will do an excellent job of spraying trees of small and medium sizes. 


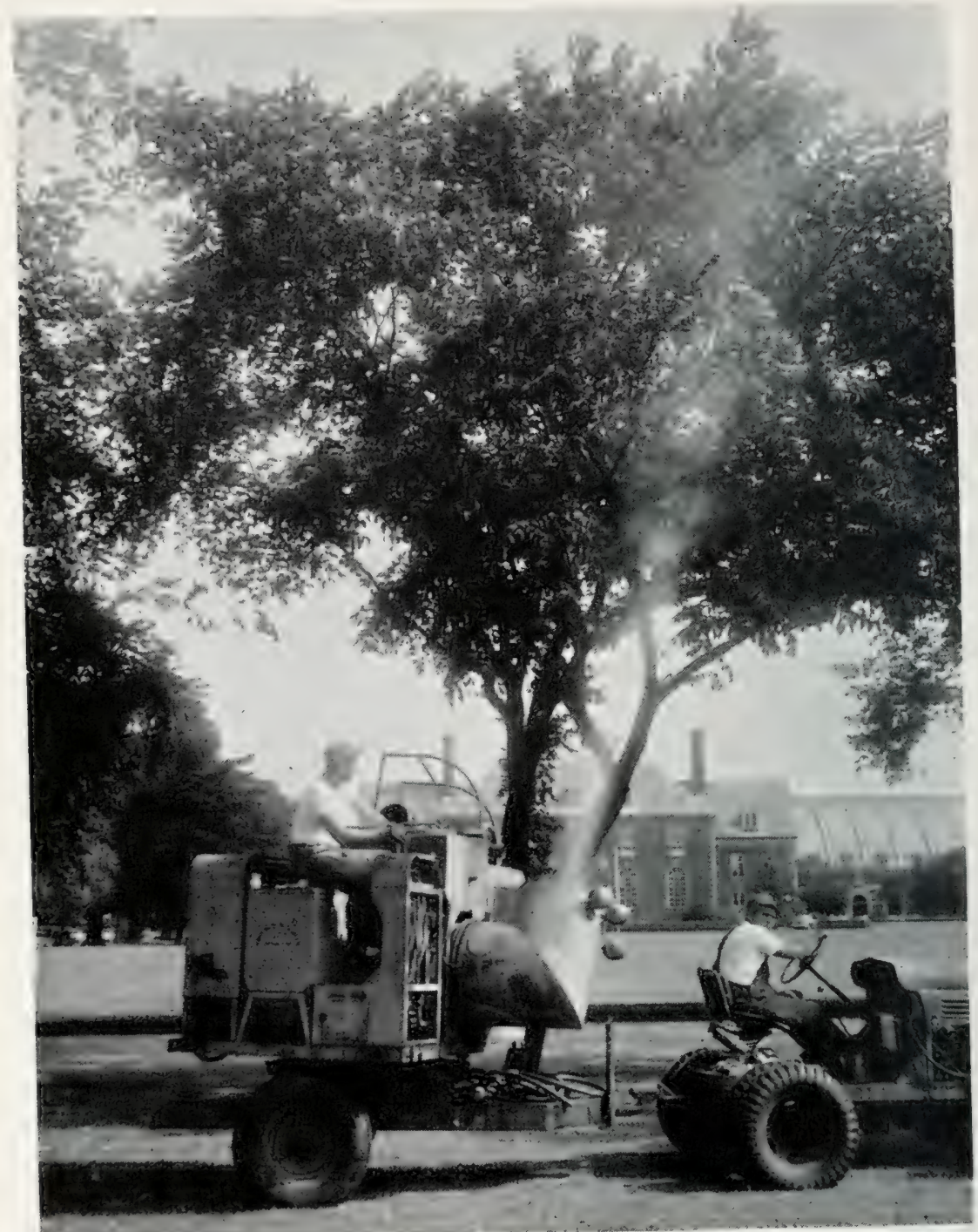

Fig. 59.-Mist blower or roto-mist sprayer in operation. This machine is particularly useful for spraying large trees. 


\section{NDEX}

This index includes technical and common names of insects and common names of trees and shrubs. Page numbers of illustrations are indicated by boldface type. A page number for a subject may indicate the beginning of the section or subsection in which the subject is discussed. Names are listed in the singular regardless of whether they appear in the text as singular or plural.

\section{A}

Aceria snetsingeri . . . . 36

Agrilus anxius . . . . . . 11

Ailanthus . . . . . . 3

webworm . . . . 3, 4

American elm (see also Elm)

$21,23,33$

Anisote mbicunda

Aphid . . . . 1,2,47

boxelder . . . . . . 12

Cooley spruce gall . 20, 21, 64

Eastern spruce gall .. 64

elm

cockscomb gall . . . . 29

leaf . . . 28, 29

Norway-maple . . . . . 47

painted maple . . . . . . 47

pine bark . . . . 56,57

spirea . . . . . . 62,63

tuliptree . . . . . . 66

willow $\quad 68,69$

woolly elm . . . . . 29

woolly hawthorn . . . 17, 17

Apple . . . 12, 17,68,75

oak (gall) . . . . 52,53

tree borer, flatheaded - $46, \mathbf{4 6 , 4 8}$

Aphis spiraecola . . . 62

Arborvitae - 5, $39,43,62,66,69$ leaf miner . . . . . . 7

Argyresthia thuiella: : 7

Ash . . $7,24,40,60,62,69$

borer . . . . . 7,8

borer, red-headed . . 6,7

mountain . . . . . 7-8

Aspen

Aspidiotus

ancylus

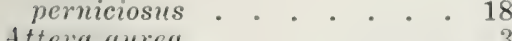

Austrian pine $: 54,57,58$

\section{B}

Bagworm . . 5, 5, 39, 43, 66, 69 Banded elm leafhopper . . . 33 Bark aphid, pine . . . . 56,57 beetle

hickory . . . . . . 36

juniper . . . 38 native elm

Beetle

smaller European elm . 31,32

elm leaf . . . . . . 24,25

cottonwood leaf . . . 60

hickory bark . . . . . 36

Japanese . . . . . 73,73

juniper bark . . . . . 38

May . . . . . . . 48

native elm bark . . . . 31

smaller European elm bark 31, 32

Birch . . . . . . . 11

borer, bronze . . . . . . 11

skeletonizer . . . . . . 11

white . . . . . 11

Bittersweet . . . . . . . 33

Black

cherry . . . . . . . . 12

locust . . . . . 40

vine weevil . . . . 69,70

walnut curculio . . . 69

Bladder gall, maple . . 15

Bladder-gall mite, maple . . 45

Blue spruce, Colorado . . . 64

Borer . . . 1, 2, 48, 59, 66, 69 ash . . . . . 7,8

bronze birch . . . . . 11

cottonwood . . . . . 59

dogwood . . . . . . 20

elm . . . . . . . 29,31

flatheaded apple tree . $46, \mathbf{4 6 , 4 8}$

locust . . . . . 4 40,42

lilac . . . . . 40,41

oak . . . . . . . 48

poplar . . . . . . 59

poplar and willow . . . . 59

red-headed ash . . . 6,7

Boxelder . . . . . . 11,13

bug . . . . . . 2, 2,11,12

aphid . . . . . . 12

Boxwood . . . . . . . 14

leaf miner . . . . . . . 14

Brachyrhinus sulcatus . . . . 69

Bronze birch borer . . . . . 11

Brown-tail moth . . . . . 75

Bucculatrix canadensisella . . 11

Bud scale, spruce . . . . 64,64

Budworm, spruce . . . . 65

Bug

boxelder . . . . 2, 2,11, 12

June . . . . . . . 48 
Bug-continued

sycamore lace

Bur oak

Butternut

65,66

50

68

\section{C}

Cankerworm, spring

$21,22,23$

Carolina poplar

Carpenterworm

Catalpa sphinx

Caterpillar

eastern tent

walnut

yellow-necked

Ceratomia catalpae

Chermes

abietis

cooleyi

Cherry, black

Chinese elm

Chinquapin

Chionaspis

cormi

furtum

Chokecherry

Choristoneura fumiferana

Chrysobothris femorata

Chrysomela scripta

Cicada, periodical

Citheronia regalis

Clavigerus smithiae

Cockscomb gall

aphid, elm

elm

Colopha vimicola

Colorado blue spruce

Comstock mealybug

Conotrachelus retentus.

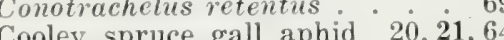

Cooley spruce gall aphid $20,21,64$
Corn silk . . . . . . 75

Comythuca ciliata . . . . . . 66

Cottonwood . . . . . 59,60 borer . . . . . . 59

leaf beetle . . . . . 60

Cottony maple scala . . . 43,44

Crab .....17,36

Curculio, black walnut . . . 69

Cynipidae . . . . . . . 53

Cynthia moth

D

\section{Datana}

integerrima . . . . . 67

ministra ...... 17

Dendrothrips omatus . . . 60

Devil, hickory horned . . . 37

Diaspis carmeli . . . . . . 37

Dichomeris marginella . . . . 38
Dioryctria zimmermani. . . . 58

Dogwood . . . . . . 20

borer......... . . 20

scale . . . . . . 20

Douglas fir . . . . 20,21,64

Drepanaphis acerifoliae . . . 47

Dutch elm disease . . . 31,32

Dysmicoccus cuspidatae . . . 73

\section{E}

Eastern

spruce gall aphid . . . . 64

tent caterpillar . . . 12, 13

Elm . 14, 21, 22, 25, 27,28, 32, 48, 75

American . . . . 21, 23, 33

aphid, woolly . . . . . 29

bark beetle

smaller European . . . 31,32

native ...... . . 31

borer . . . . 29, 31

Chinese . . . . . . 24

cockscomb gall . . . . 30

aphid . . . . . . . 29

disease, Dutch . . . . 31, 32

leaf

aphid . . . . . 28, 29

beetle . . . . . 24, 25

leafhopper, banded . . . 33

scale, European . . . 25, 26

spanworm . . . . . . 40

Engelmann spruce . . . . 64

Ennomos subsignarius . . . 40

Eotetranychus multidigituli . . 43

Eriosoma

americanum . . . . . . . 29

crataegi . . . . . . 17

Euonymus . . . . . . 33,34

scale . . . . . . 33,34

European

elm

bark beetle, smaller . . 31, 32

scale . . . 25, 26

pine shoot moth . . . . 57

red mite. . . . . . . 18

\section{F}

Fall webworm . . . . 9, 10,24

Flatheaded apple tree borer $46,46,48$

Fletcher scale . . . . 71,71

Fir, Douglas ..... 20, 21,64

\section{G}

Galemeclla xanthomelaena . . 24

Gall

aphid

Cooley spruce . . . 20, 21,64

eastern spruce . . . . 64

elm cockscomb . . . . 29 
elm cockscomb

gouty oak
maple bladder

mite, maple bladder- . . . 45

oak apple . . . 52,53

phylloxera, hickory . . 37

psyllid, hackbexry nipple . . 35

wool sower

52,53

Gall-producing

insect . . . . . . 3,53

mite . . . . . . . 3

Gouty oak gall . . . 52,53

Gossyparia spuria . . . . 26

Grape . . . . . . 75

Green-striped mapleworm . 46

Gypsy moth . . : 74,75

\section{H}

Hackberry . . . . . . 35, 35

nipple gall psyllid ... 35

witches'-broom . . . . . 35

Hard maple . . . . . . 47

Hawthorn . . 17, 17, 19, 36 aphid, woolly . . 17,17 leaf miner . . . . . 19, 20

Hemerocampa leucostigma . 23

Hickory . . . . . 36, 48, 68 bark beetle . . . . 36

gall phylloxera . . . . . 37

horned devil . . . . . . 37

Homadaula albizziae . . . 43

Honey locust . . . . . 43, 68

Horned devil, hickory . . . 37

Hylurgopinus rufipes . . . . 31

Hypermallus villosus . . . 48

Hyphantria cunea. . . . . 9

Ichneumonidae ...... 47

Ichthyura inclusa . . . . . 60

Insect enemies, potential : : 73

Insect

gall-producing . . . . 3.53

scale...... 1,2

\section{J}

Jack pine

$54,57,58$

Japanese beetle $\cdot 73,73$

June bug . . . . . . 48

Juniper $\cdots 7,37,38,62$ bark beetle . . . . 38 scale..... $7,37,38$ webworm . . . . 38, 39

\section{K}

Kermes, oak . . . . . 50,50

Kermes pubescens . . . . 50
Lace bug, sycamore . . . $\mathbf{6 5}, 66$

Lady beetle . . . . . . 2

Leaf

aphid, elm . . . . . 28, 29

beetle

cottonwood . . . . . . 60

elm . . . . 24, 25

eater . . . . . . 3

miner . . . . . . . . 51

arborvitae . . . . . 7

boxwood . . . . . 14

hawthorn . . . 19, 20

oak . . 51

Leafhopper, banded elm . . . 33

Lecanium fletcheri. . . . . . 71

Lepidosaphes ulmi . . . . 8

Leptocoris trivittatus . . . 11

Lilac . . . . . . 40,41

borer . . . . 7, 40,41

Linden . . . . . . 40

moth, snow-white . . . 40

Locust . . . . . 40,42

black . . . . . 40

borer . . . . . 40,42

honey . . . . . . 43,68

mite . . . . . . 43

Lombardy poplar . . . . . 59

Louse (lice), plant . . . . 2

\section{M}

Macrosiphum liriodendri . . . 66

Magicicada septendecim : . . 48

Malacosoma americanum . . 12

Maple . . $6,14,43,47,48,75$ aphid

Norway- . . . . . . 47

painted . . . . 47

bladder gall . : . 45

bladder-gall mite . . 45, 45

hard . . . . . . 47

Norway . . . . . . 47

scale, cottony . . . . 43, 44

$43,44,45,45$

Mapleworm, green-striped . . 46

May bretle . . . . . . . . . 48

Mealybug

Com-tock . . . . . 16

taxus . . . . 72,73

Megacyllene robiniae. . . . 40

Metatetranychus ulmi . . . 18

Mimosa . . . . . . . . . 43

webworm . . . . . 43

Miner

arborvitae leaf . . . . 7

boxwood leaf . . . . 14

hawthorn leaf . . . . 19,20

oak leaf . . . . . . 51

Mite . . . . . . 3.33 
Mite-continned

European red gall-producing locust

maple bladder-gall

spruce spider two-spotted spider

Monarthropalpus buxi

Moth

brown-tail

cynthia

copean pine shoot..: 57

gypsy . . . . . . 74,75

Nantucket pine . . . 57,58

regal . . . . . . . 37

snow-white linden . . . . 40

white-marked tussock . . 23, 21

Zimmerman pine .... . 58

Mountain ash . . . . 7,8

Mugho pine . . . . . . 54,57

Myzocallis ulmifolii . . . . 29

\section{N}

Native elm bark beetle . . . . 31

Nantucket pine moth . . 57,58

Needle scale, pine . . 54,55,65

Neoclytus acuminatus . . . . 7

Neodiprion spp. . . . . . 53

Nipple gall psyllid, hackberry . 35

Norway maple . . . . . . 47

Norway-maple aphid . . . . 47

Norway spruce . . . . . . 64

Nygmia phaeorrhoea... . . 75

\section{0}

Oak . . 14, 48, 51, 53, 68, 75 apple gall . . . . . 52,53 bur ......... . 50 gall

gouty . . . . . 52,53

wool sower . . . 52,53

kermes . . . . . 50, 50

leaf miner . . . . . . 51

red ....... 50,53

white....... 50

Oligonychus ununguis . . . 62

Oystershell scale - $8,9,40,60,62,69$

P

Pachypsylla celtidis-mamma . 35

Pachysandra . . . . . . 33

Painted maple aphid . . . . 47

Paleacrita vemata . . . . . 21

Pear . . . . . . . . 75

Periodical cicada . . . . 48, 49

Periphyllus

lyropictus . . . . . . 47

negundinis . . . . . 12
Phenacaspis pinifoliae . . . . it

Phloem necrosis . . . . . . . 33

Phloeosinus dentatus . . . . . 38

Phyllophaga spp. . . . . . 48

Phylloxera caryaccaulis . . . 37

Phylloxera, hickory gall . . . 37

Physokermes piceae . . . . . 64

Pigeon tremex . . . . . . 47

Pine . . . 53, 54, 55, 58

Austrian . . . . 54,57,58

bark aphid . . . . 56,57

jack . . . . . 54,57,58

moth

Nantucket . . . . . 57,58

Zimmerman . . . . . 58

Mugho . . . . . . 54, 57

needle scale . . . . 54,5, 6.5

red . . . . . 57,58

sawfly, red-headed . . . . 54

Scotch . . 54,57,58

shoot moth, European . . . 57 white.... 54,56,57

Pineus strobi....... . . 5T

Pissodes strobi . . . . . . 54

Plant louse (lice) . . . . . . 2

Plectrodera scalator . . . . . 59

Plum . . . . . . . T5

Podosesia

syringae

fraxini ....... . .

syringae . . . . . . . 40

Popillia japonica . . . . . 73

Poplar . . . . 48, 59, 69

and willow borer . . . . 59

borer ...... . . 59

Carolina . . . . . . . 59

Lombardy . . . . . . . . 59

tent maker . . . . . . . 60

Porthetria dispar . . . . . . 75

Potential insect enemies . . . 73

Prionoxystus robiniae . . . . 5?

Privet . . . . . . . 60

thrips..... . . 60

Profenusa canadensis . . . 20

Pruner, twig . . . . . . . 48

Pseudococcus comstocki . . . . 16

Psyllid, hackberry nipple gall . 35

Pulvinaria innumerabilis . . . 4;

Putnam scale . . . . . 27,28

\section{$\mathbf{R}$}

Redbud

62

Red-headed

ash borer . . . . . 6.7

pine sawfly... . . . . 51

Red

mite, European . . . . . 18

oak . . . . 50,53

pine . . . . . . 57,58

Regal moth . . . . . . . 37 
Reticulitermes spp. . . . . 71

Rhyacionia

buoliana

frustrana

S

Sumia cynthia

San Jose scale

Saperda

calcarata

tridentata

Sawfly

red-headed pine

Scale

cottony maple

dogwood

euonymus

European elm

Fletcher

insect

juniper.

oystershell

pine needle

Putnam

San Jose .

scurfy

spruce bud

tuliptree

Scolytus

multistriatus . . . . . . 31

quadrispinosus . . . . 36

Scotch pine . . . 54,57,58

Scurfy scale . . . . 26, 27

Shadbush . . . . . . 29

Shoot moth, European pine . 57

Sitka spruce ..... . . 64

Skeletonizer, birch . . . . 11

Smaller European

elm bark beetle . . 31, 32

Snow-white linden moth . . 40

Soft maple . . $42,4:, 45,45$

Soybean . . . . . 75

Spanworm, elm ..... 40

Sphaerotheca phytoptophila. 36

Sphinx, catalpa . . . . 14, 15

Spider mite

spruce - . . $7,39,62$

two-spotted . . $33,61,62$

Spirea . . . . 62,63

aphid . . . . . . 62,63

Spring cankerworm . 21, 22, 23

Spruce . . . . $7,62,64$

bud scale . . . 64,61

budworm . . . 65

Colorado blue . : 64

Engelmann . . . . . 64

gall aphid

Cooley

eastern
Norway . . . . . . 64

Sitka . . . . . 64

spider mite . . . . $7,39,62$

Sternochetus lapathi. . . 59

Sycamore . . . . 66

lace bug . . . . 65,66

\section{T}

Taxus (see also Yew) . . . 69

mealybug . . . . . 72,73

Tent

caterpillar, eastern . . 12, 13

maker, poplar . . . . . 60

Termite . . . . 71

Tetranychus telarius $\cdots 33,62$

Thamnosphecia scitula . . . 20

Thrips, privet . . . . 60

Thyridopterix ephemeraeformis 5

Toumyella liriodendri . . . 66

Tree

borer, flatheaded apple . 46, $\mathbf{1 6 , 4 8}$ of heaven . . . . . 3

Tremex columba : : : . 47

Tremex, pigeon . . . . 47

Tuliptree . . . . . 66

aphid . . . . . 66

scale . . . 66

Tussock moth, white-marked 23, 21

Twig pruner . . . . 48

Two-spotted spider mite . $3 \dot{3}, \mathbf{6} 1,62$

\section{U}

Unaspis eronymi . . . . . 33

Vasates quadripedes . . . . 45

Vine weevil, black .. 69,70

\section{W}

Walnut . . . . . 67

caterpillar $\div 67,67$

curculio, black . . 69

Weevil

black vine . . . . . 69,70

white-pine . . . 54

Webworm

ailanthus . . . . . 3,4

fall . . . $9,10,24$

juniper . . . 38,39

mimosa . . . . 43

White-marked tussock moth 23,21

White

birch . . . . . . . 11

oak $\div 50$

pine . . . 54,56,57

weevil . . . 54

Willow $\therefore 60,68,69,75$ 
Willow-contimed \begin{tabular}{ll} 
aphid . & \\
borer, poplar and . . . & 68,69 \\
\hline & 59
\end{tabular}

Witches'-broom . . . . $\mathbf{3 5 , 3 6}$

Wool sower gall . . . . 52,53

Woolly

elm aphid . . . . . . . 29

hawthorn aphid . 17,17
Y

Yellow-necked caterpillar $16,17,36$ Yew (taxus) . . 69,70,71,72

z

Zimmerman pine moth . . . 58 


\section{SPRAY PREPARATION TABLES}

Table 1.-Proportionate quantities of liquid insecticides required to make various quantities of spray.

\begin{tabular}{|c|c|c|c|c|}
\hline $\begin{array}{l}\text { Gallons } \\
\text { of Spray } \\
\text { Desired }\end{array}$ & \multicolumn{4}{|c|}{ Quantity of Liquid Insecticide } \\
\hline 100 & 1 pint & 1 quart & 1 gallon & 2 gallons \\
\hline 50 & $1 / 2$ pint & 1 pint & 2 quarts & 1 gallon \\
\hline 25 & $1 / 4$ pint & $1 / 2$ pint & 1 quart & 2 quarts \\
\hline 5 & 2 tablespoons & 4 tablespoons & 6 ounces & 12 ounces \\
\hline 1 & 1 teaspoon & 2 teaspoons & 3 tablespoons & 5 tablespoons \\
\hline
\end{tabular}

Table 2.-Proportionate quantities of powdered insecticides required to make various quantities of spray.

\begin{tabular}{|c|c|c|c|c|}
\hline \multirow{2}{*}{$\begin{array}{c}\text { Gallons } \\
\text { of Spray } \\
\text { Desired } \\
100\end{array}$} & \multicolumn{4}{|c|}{ Quantity of Powdered Insecticide } \\
\hline & 1 pound & 2 pounds & 4 pounds & 8 pounds \\
\hline 50 & $1 / 2$ pound & 1 pound & 2 pounds & 4 pounds \\
\hline 25 & $1 / 4$ pound & $1 / 2$ pound & 1 pound & 2 pounds \\
\hline 5 & 1 tablespoon* & 2 tablespoons* & 4 tablespoons* & 8 tablespoons* \\
\hline 1 & 1 teaspoon ${ }^{\dagger}$ & 4 teaspoons $\dagger$ & 1 tablespoon* & 2 tablespoons* \\
\hline
\end{tabular}

*Heaping †Level 


\section{CONTROL MEASURES}

Following are the control measures mentioned on previous parges of this circular. In most instances, formulas given are for 100 gallons of spray. The amounts of insecticides to be used for small quantities of spray can be calculated from information given in tables 1 and 2, page 89 .

Control Measure 1.-Apply a lead arsenate spray: 4 pounds of lead arsenate to 100 gallons of water.

Control Measure 2.-Apply a DDT spray: 2 pounds of 50 per cent DDT wettable powder or 2 quarts of 25 per cent DDT emulsifiable concentrate to 100 gallons of water. Both lead arsenate and DDT are effective against most leaf-eating insects. Where either insecticide will do the job, lead arsenate should be userl, because of the aphid and mite infestations likely to follow repeated use of DDT.

Control Measure 3.-Apply a malathion spray: 1 quart of 50 per cent malathion emulsifiable concentrate or 4 pounds of 25 per cent malathion wettable powder to 100 gallons of water. CAUTION: Malathion may injure Cannart red cedar, Juniperus virginiana cannarti.

Control Measure 4.-Prevention of borer attack is more successful than attempts at a cure. To discourage borer attack, keep the trunks of newly set trees wrapped with heavy paper for the first 2 years, or until the trees are established and growing vigorously. Special paper, 3 to 4 inches wide, in rolls suitable for spiral wraps can be purchased. Start the wrap just below the lowest branch and spiral it downward to the ground. Heap soil around the base of the tree to close the space between the wrap and the ground. Secure the wrapping in place with stout twine, fig. 54. Keep the soil well watered, as drought-weakened trees are attractive to borers.

Borer attack can be prevented, for the most part, by a DDT spray applied to tree trunks: 4 pounds of 50 per cent DDT wettable powder or 1 gallon of 25 per cent DDT emulsifiable concentrate to 100 gallons of water. Designed to kill young borers as they hatch from eggs on the bark, the spray should be applied at monthly intervals throughout the summer, beginning about May 1. Application of DDT to the entire tree is not recommended unless necessary, as such application may result in serious infestations of mites and aphids. A durable insecticide deposit can be 
made from DDT, powdered skim milk, and water. To a mixture of 4 parts of 50 percent DDT wettable powder and 1 part of powdered skim milk, enough water is added to make a smooth slurry that can be applied to the trunks of trees with a paint brush. Dead and dying branches should be pruned from infested trees and burned. Borers in the wood can be killed if the tunnels are cleaned out with a piece of wire and carbon disulfide or nicotine sulfate is injected into the holes with an oil can. The holes should be plugged with putty after treatment. Carbon disulfide is highly inflammable and can be ignited by a spark or cigarette.

Control Measure 5.-Apply an oil spray while the plants are dormant: use an emulsifiable dormant oil diluted with water according to directions of the manufacturer.

Control Measure 6.-Clip off and destroy infested branches or burn out the webs with a torch.

Control Measure 7.-Eliminate local infestations by spraying the bugs on the trunks of trees and on the foundations of buildings with a lindane or a dieldrin preparation: 1 pint of 20 per cent lindane emulsifiable concentrate to 5 gallons of water, or 1 pint of 20 per cent dieldrin emulsifiable concentrate to 10 gallons of water. Repeat applications as needed.

Control Measure 8.-Apply a lindane spray : 1 pint of 20 per cent lindane emulsifiable concentrate or 1 pound of 25 per cent lindane wettable powder to 100 gallons of water.

Control Measure 9.- Spray with one of the following materials: 11 to 2 pounds of 15 per cent Aramite wettable powder or 25 per cent chlorobenzilate wettable powder to 100 gallons of water. Or use Control Measure 3 at 2-week intervals until the infestation is eliminated.

Control Measure 10.- Spray with one of the following materials: 1 quart of 20 per cent lindane emulsifiable concentrate or 1 quart of 15 per cent dieldrin emulsifiable concentrate to 100 gallons of water.

Control Measure 11.- Spray with toxaphene: 3 quarts of 60 per cent toxaphene emulsifiable concentrate to 100 gallons of water.

Control Measure 12.- In late winter, apply a lime sulfur spray: 1 gallon of liquid lime sulfur to 10 gallons of water. CAUTION: Lime sulfur will blacken house paint.

Control Measure 13.-Apply a DDT spray: 2 gallons of 25 per cent DDT emulsifiable concentrate to 100 gallons of water. 
Control Measure 14.-Apply a lindane spray: 2 quarts of 20 per cent lindane emulsifiable concentrate to 100 gallons of water.

Control Measure 15.-Apply an aldrin spray : 2 quarts of 25 per cent aldrin emulsifiable concentrate to 100 gallons of water.

Control Measure 16.- Spray with aldrin, dieldrin, or heptachlor: 1 pound of actual toxicant per 100 gallons of water. This rate means 2 pounds of 50 per cent or 4 pounds of 25 per cent wettable powder per 100 gallons of water.

Control Measure 17.- Inject diluted chlordane under and around the root mass. For medium-sized plants, use about 1 gallon of a mixture containing 1 gallon of 45 per cent chlordane emulsifiable concentrate to 100 gallons of water.

Control Measure 18.- - Remove and burn all dead and dying elm trees, limbs, and branches before European elm bark beetles emerge in the spring. Also promptly remove and burn trees infected with Dutch elm disease. Bark beetle feeding and the spread of Dutch elm disease can be reduced by spray applications of special DDT formulations, but the practical aspects and limitations of such a spray program should be well understood before it is undertaken. Special information on Dutch elm disease and phloem necrosis is available from the Illinois Natural History Survey, Natural Resources Building, Urbana, Illinois.

Control Measure 19.-Promising results in control of the periodical cicada have recently been obtained with a spray containing 1 pound of 50 percent Serin per 100 gallons of water. Small trees can be protected by a covering of cheesecloth over each tree.

Control Measure 20.-Gather up and burn infested twigs. 



\section{Some Recent Publications of the}

\section{Iluinors Natural History Survey}

\section{BULLETIN}

Volume 26, Article 1.-The Mayflies, or Èphemeroptera, of Illinois. By B. D. Burks. May, 1953. 216 pp., frontis., 395 figs., bibliog. \$1.25. Volume 26, Article 2.-Largemouth Bass in Ridge Lake, Coles County, Illinois. By George WV. Bennett. November, 195t. 60 pp., frontis., 15 figs., bibliog.

Volume 26, Article 3.-Natural Availability of Oak Wilt Inocula. By E. A. Curl. June, 1955. 48 pp., frontis,, 22 figs., bibliog.

Volume 26, Article 4.-Efficiency and Selectivity of Commercial Fishing Devices Used on the Mississippi River. By William C. Starrett and Paul G. Barnickol. July, 1953. 42 pp., frontis., 17 figs., bibliog.

Volume 26, Article 5.-Hill Prairies of Illinois. By Robert A. Evers. August, 1955. 80 pp., frontis., 28 figs, bibliog.

Volume 26, Article 6.-Fusarium Disease of Gladiolus: Its Causal Agent. By Junius L. Forsberg. September, 1955. 57 pp., frontis., 22 figs., bibliog.

Volume 27, Article 1.-Ecological Life History of the Warmouth. By R. Weldon Larimore. August, 1957. 84 pp., color frontis., 27 figs., bibliog.

\section{CIRGULAR}

39.-How to Collect and Preserve Insects. By H. H. Ross. June, 1953. (Fourth printing, with alterations.) 59 pp., frontis., 65 figs.

42.-Bird Dogs in Sport and Conservation. By Ralph E. Yeatter. December, 1948. 64 pp., frontis., 40 figs.

43. - Peach Insects of Illinois and Their Control. By Stewart C. Chandler. December, 1950. 63 pp., frontis., 39 figs.

45.--Housing for Wood Ducks. By Frank C. Bellrose. February, 1955. (Second printing, with revisions.) 47 pp., illus., bibliog. 46.-Illinois Trees: Their Diseases. By J. Cedric Carter. August, 1955. 99 pp., frontis, 93 figs. Single copies free to Illinois residents; 25 cents to others.

\section{BIOLOGICAL NOTES}

28.-Home Pools and Homing Behavior o Smallmouth Black Bass in Jordan Creeh By R. Weldon Larimore. June, 1952. 1 pp., 5 figs., bibliog.

29.-An Inventory of the Fishes of Jorda Creek, Vermilion County, Illinois. By F Weldon Larimore, Quentin H. Pickering and Leonard Durham. August, 1952. 2 pp., 25 figs., bibliog.

30.- Sport Fishing at Lake Chautauqua, nea Havana, Illinois, in 1950 and 1951. B William C. Starrett and Perl L. McNei Jr. August, 1952. 31 pp., 22 figs., bibliog. 31.-Some Conservation Problems of th Great Lakes. By Harlow B. Mills. Octe ber, 1953. (Second printing.) 14 pp., illus bibliog.

32.- Some Facts About Illinois Snakes an Their Control. By Philip W. Smith. N vember, 1953. 8 pp., 11 figs. 10 cents.

33.-A New Technique in Control of th House Fly. By Willis N. Bruce. Decen ber, 1953. 8 pp., 5 figs.

34.-White-Tailed Deer Populations in III nois. By Lysle R. Pietsch. June, 1954. pp., 17 figs., bibliog.

35.-An Evaluation of the Red Fox. H Thomas G. Scott. July, 1955. (Secon printing.) $16 \mathrm{pp}$., illus., bibliog.

36. - A Spectacular Waterfowl Migrati Through Central North America. By Frar C. Bellrose. April, 1957. 24 pp., 9 fig: bibliog.

37.-Continuous Mass Rearing of the Eur: pean Corn Borer in the Laboratory. I Paul Surany. May, 1957. 12 pp., 7 figs.

\section{MANUAL}

3.-Fieldbook of Native Illinois Shrubs. ] Leo R. Tehon. December, 1942. $307 \mathrm{p!}$ + color pls., 72 figs., glossary, index. $\$ 1.7$ 4.-Fieldbook of Illinois Mammals. By Dona F. Hoffmeister and Carl O. Mohr. Jun 1957. 233 pp., color frontis., 119 figs., glo sary, bibliog., index. $\$ 1.75$.

\section{List of available publications mailed on request.}

Single copies of Ilinots Natur.i. History Survey publications for which no price is liste will be furnished free of charge to individuals until the supply becomes low, after which nominal charge may be made. More than one copy of any free publication may be obtain without cost by educational institutions and official organizations with the State of Illinoi prices to others on quantity orders of these publications will be quoted upon request.

\section{Address orders and correspondence to the Chief Illinois Natural History Survey Natural Resources Building, Urbana, Illinois}

Payment in the form of money order or check made out to State Treasurer of Illino Springfield, lllinois, must accompany requests for those publications on which a price is s. 



UNIVERSITY OF ILLINOIS-URBANA

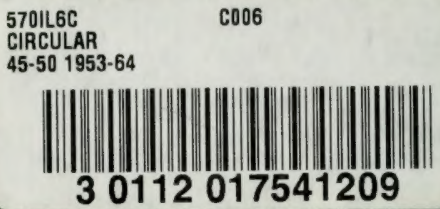

45-50 1953-64 ||||||||||||||||||||||||||||||||||||||||||||||||||||||||||||||||||||||||||||||||||||||||||||||||||||| 30112017541209 